DEPARTMENT OF THE INTERIOR

UNITED STATES GEOLOGICAL SURVEY

CHARLES D. WALCOT'T', DIRECTOK

\title{
ECONOMIC GEOLOGY
}

OF THE

\section{IOLA QUADRANGLE, KANSAS}

BY

GEORGE I. ADAMS, ERASMUS HAWORTH, AND W. R. CRANE

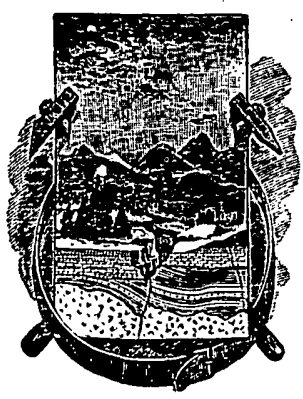

WASHINGTON

GOVERNMENT PRINTING OFFICE

1904 



\section{ERRATA.}

[Bull. U. S. Geol. Survey No. 238.]

The work of Mr. F. C. Schrader in the adjacent Independence and Parsons quadrangles during the season of 1904 shows that certain miscorrelations were made in the survey of the Iola quadrangle. The necessary corrections have been made on the maps (Pls. I and II), and the data for correcting the text and Pls. III and IV are given below:

Pl. III, for Irum read Dennis.

for Cherryvale read Galesburg.

for Dennis read Mound Valley.

for Galesburg read Ladore.

Pl. TV, for Drum read Dennis.

for Dennis read Mound Valley.

Page 3, line 20, for Galesburg read Ladore.

line 21, for Dennis read Mound Valley.

line 22, for Cherryvale read Galesburg.

line 23, for Drum read Dennis.

Page 18, paragraph 1, line 10, for Galesburg read Ladore.

line 11, for Dennis read Mound Valley. for Cherryvale read Galesburg. for Drum read Dennis.

paragraph 4, line 1, for Galesburg read Ladore:

paragraph 5, line 1, for Dennis read Mound Valley.

paragraph 6, line 1, for Cherryvale read Galesburg.

Page 19, paragraph 1, line 1, for Drum read Dennis.

line 7, for Drum read Dennis.

paragraph 2, line 3, for Drum read Dennis.

line 4, for Dennis read Mound Valley.

line 5, for Galesburg read Ladore.

paragraph 3, line 2, for Drum read Dennis.

for Cherryvale read Galesburg.

Page 21, paragraph 5, line 5, for Galesburg read Ladore.

for Dennis read Mound Valley. for Cherryvale read Galesburg.

Page 22, line 17, for Drum read Dennis. for Drum read Dennis.

line 18, for Cherryvale read Galesburg.

line 19, for Dennis read Mound Valley.

line 20, for Galesburg read Ladore.

Page 75, paragraph 2, line 3, for Shaw read Dennis.

Page 79, line 14 from bottom, for Dennis read Mound Valley. for Drum read Dennis. 



\section{CON'TEN'TS.}

Page.

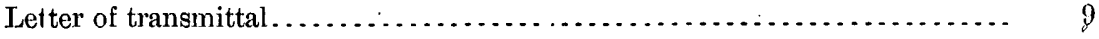

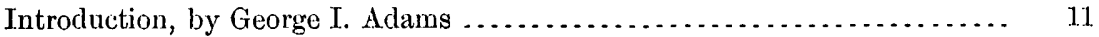

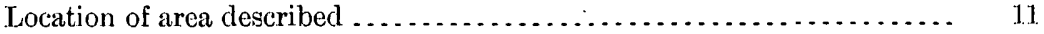

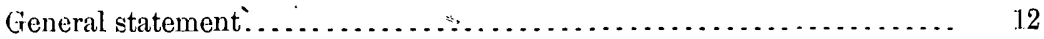

Geology of the Iola quadrangle, by George I. Adams . . . . . . . . . . . . . . . 14

Surface features . . . . . . . . . . . . . . . . . . . . . . . . . . . . 14

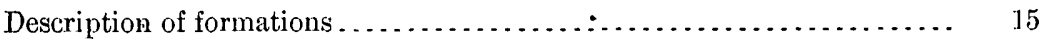

Mississippian series. . . . . . . . . . . . . . . . . . . . 15

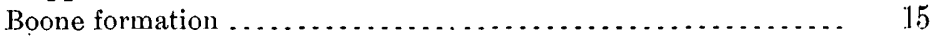

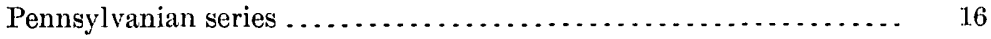

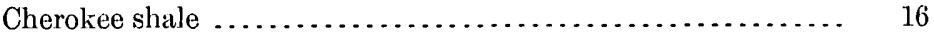

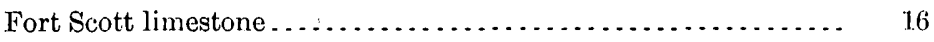

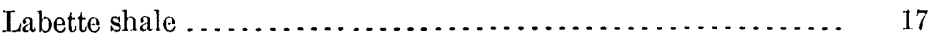

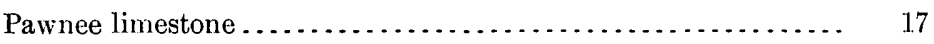

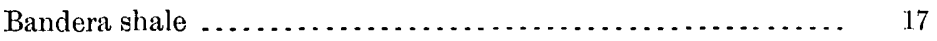

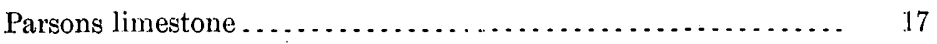

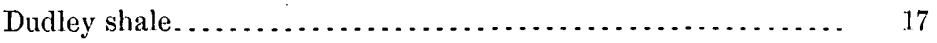

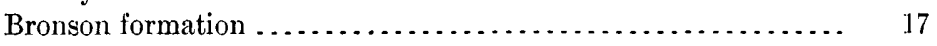

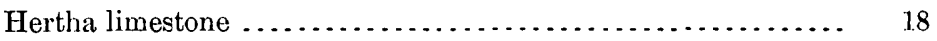

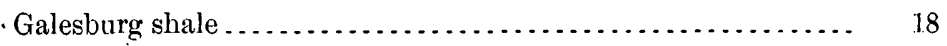

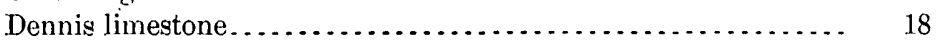

Cherryvale shale ................................. 18

Drum limestone....................................... 19

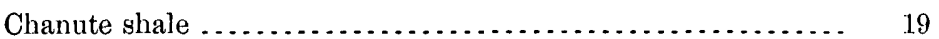

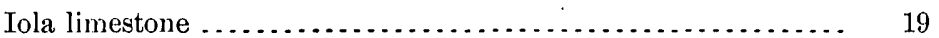

Concreto shale .................................. 20

Allen limestone ................................. 20

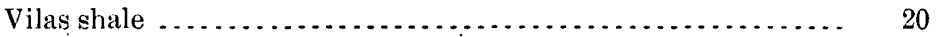

Piqua limestone..................................... 20

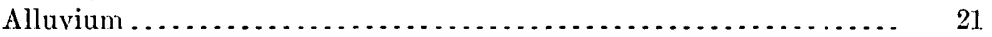

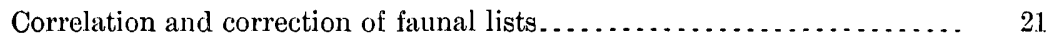

General structure . . . . . . . . . . . . . . . . . . . . .

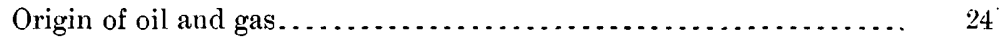

Relations of the oil- and gas-bearing sandstones ............... 25

Mineral resources and their utilization, by Erasmus Haworth and George I.

Adams, with sections by W. R. Crane .................... 30

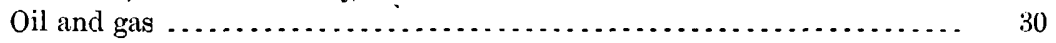

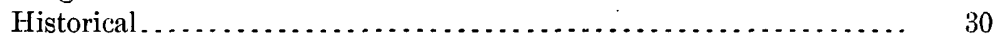

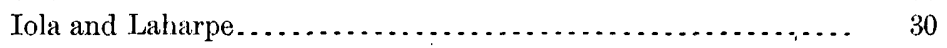

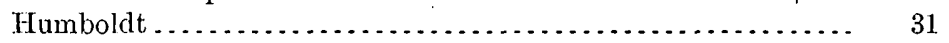

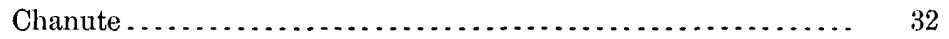

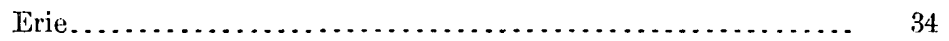

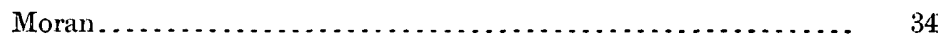

Bronson, Elsmore, Savonburg, and Stark ................ 34 
Mineral resources and their utilization, etc.-Continued.

Page.

Oil and gas-Continued.

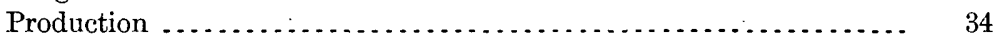

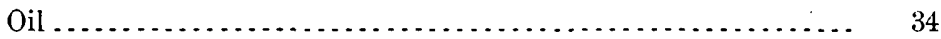

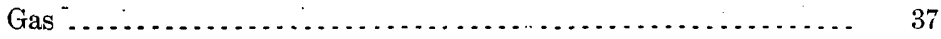

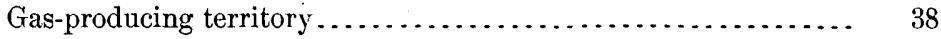

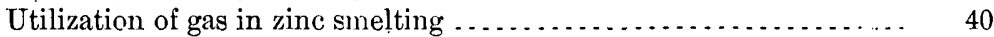

Development of the industry $\ldots \ldots \ldots \ldots \ldots \ldots \ldots \ldots \ldots . . \ldots \ldots$

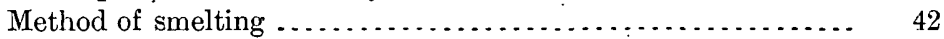

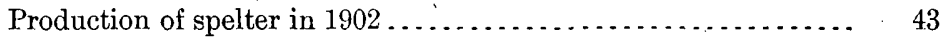

Phenomena of gas wells, by George I. Adams ................ 43

Static or closed pressure ............................ 45

Dynamic or open-flow pressure...................... 47

Pressure and flow in pipes ......................... 50

Minute pressure, or measurement of volume by number of condensations.

Observations and measurements of gas wells in the Iola quadrangle, by W. R. Crane.

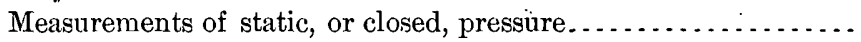

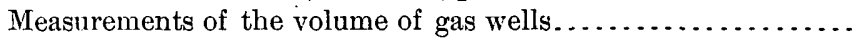

Measurements of flow of gas in pipes...................

Observations on methods of developing and utilizing oil and gas, by

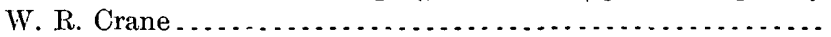

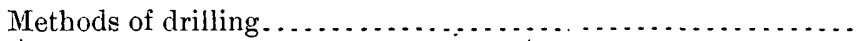

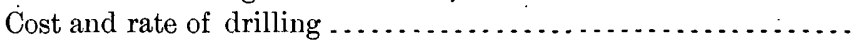

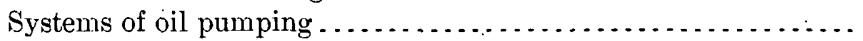

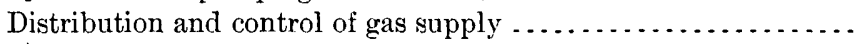

Portland cement . . . . . . . . . . .

Types of silicate cements. . . . . . . . . . . . . . . . . $\ldots \ldots \ldots \ldots$

Puzzolan cement . . . . . . . . . . . . . . . . . . . . . . . . .

Natural cement ..................................

Portland cement . . . . . . . . . . . . . . . . . . . . . . . . . . .

Chemical composition of Portland cement. .................

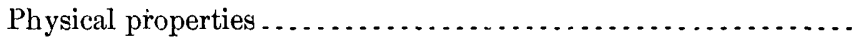

Raw materials used in the manufacture of Portland cement .........

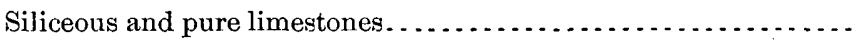

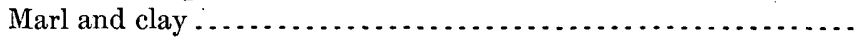

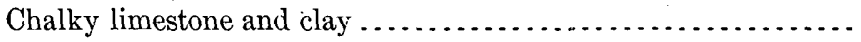

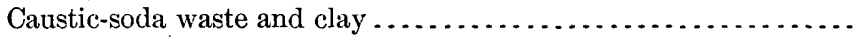

Slag and limestone. . . . . . . . . . . . . . . . . . . . . . . . . . .

Pure (hard) limestone and clay or shale. . . . . . . . . . . . . .

Cement materials in the Iola quadrangle ....................

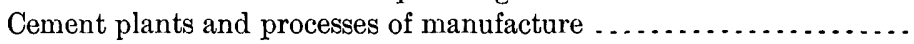

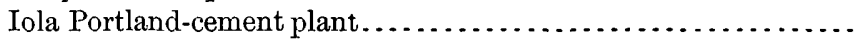

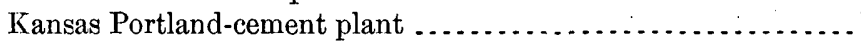

Brick making .

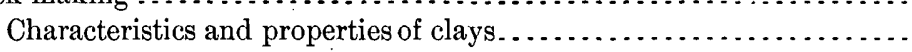

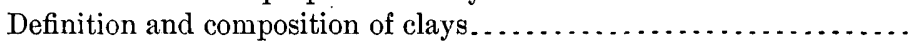

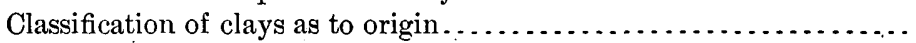

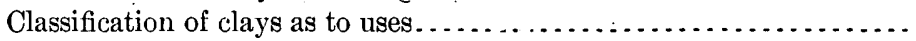

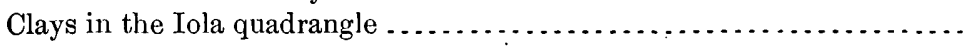

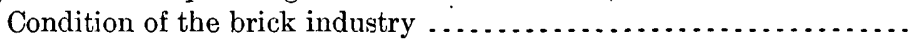

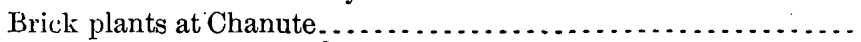

Brick plants at Humboldt. . . . . . . . . . . . . . . . . . . . . . . . 
Mineral resources and their utilization, etc.-Continued. Page. Brick making-Continued.

Clays in the Iola quadrangle-Continued.

Brick plants at Iola . . . . . . . . . . . . . . . . . . . .

Brick plants at Laharpe.............................. 74

Coal, lead, and rinc............................................ 74

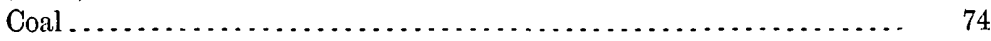

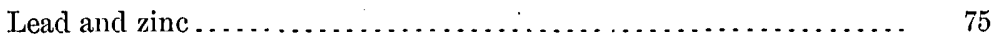

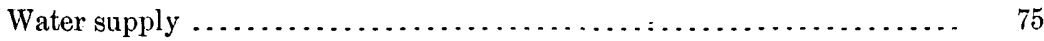

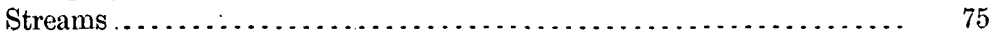

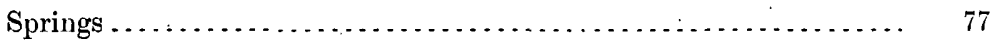

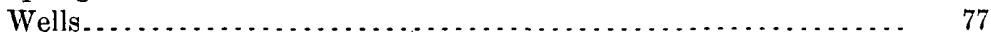

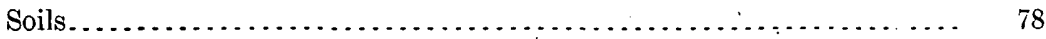

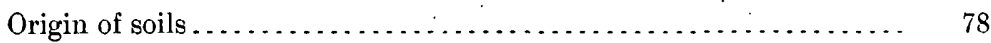

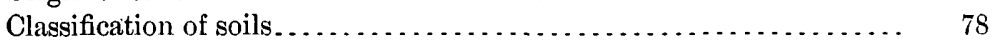

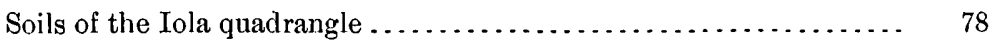

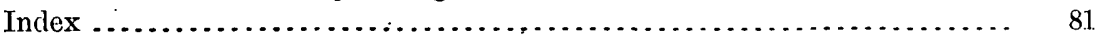





\section{L L US TR R T I O N S}

Plate I. Geologic map of the Iola quadrangle, showing location of oil and gas wells in September, 1903 .................................

II. Geologic map and section, showing structural relations of the oil- and gas-bearing iormations of the Iola quadrangle................

III. General section of rocks exposed in the Iola quadrangle and encountered in drilling........................................

IV. $A$, Geologic section through Moran, Laharpe, and Iola; $B$, Geologic section through Erie, Shaw, and Chanute....................

V. Relative positions and partial logs of wells just east of Chanute, Kans..............................................

VI. Golden Oil Company's well No. 2, near Chanute, Kans.............

VII. Knapp pumping station, storage tanks, and loading racks, Chanute,

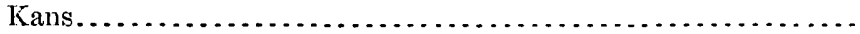

VIIT. $A$, Iola Brick Company's plant No. $1 ; B$, Lanyon Zinc Company's smelter No. 1.......................................

IX. A, Tanyon Zinc Company's smelter No. 2; B, Bank of retorts showing flames and rinc fumes escaping from the ends of the condensers..........................................

X. $A$, Chart of static pressure in service pipe taken with Bristol's recording pressure gage; $B$, Chart of static flowage pressure in service pipe taken with Bristol's recording pressure gage...............

XI. $A$, Limestone quarry at Iola Portland Cement Company's plant; $B$, Iola Portland Cement Company's plant........................

Page.

FIc. 1. Sketch map showing location of Iola quadrangle (Pl. I) and area shown in Pl. II....................................

2. Sketch illustrating disappearance of sandstone beds..............

3. Relative positions and partial logs of certain wells of the Kansas Crude Oil and Oread Oil and Gas companies.........................

4. Spring gage attached for measuring static pressure...............

5. U-shaped gage with flexible hose for attachment in measuring gas

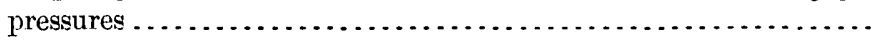

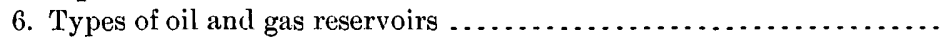

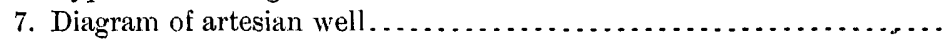

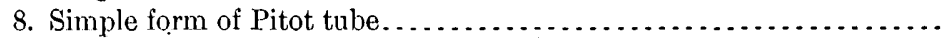

9. Pitot tube and spring gage attached for measuring velocity of gas issuing from a well

10. Pitot tube and spring gage attached for measuring velocity of flow of

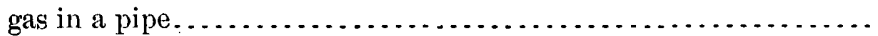

11. Spring gage attached for measuring internal pressure of gas flowing in a pipe.

12. Robinson instrument for measuring velocity and pressure of gas flow-

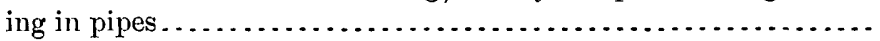

13. Map of Iola quadrangle showing approximately zones of variation of static pressure of gas wells .............................. 



\title{
LETTER OF TRANSMITTAL.
}

\author{
Department of the Interior, \\ United States Geological Survey, \\ Washington, D. C., May 17, 1904.
}

SIR: I have the honor to transmit herewith the manuscript of a report on the economic geology of the Iola quadrangle, Kansas, by George I. Adams, Erasmus Haworth, and W. R. Crane, and respectfully recommend that it be published as a bulletin.

The report contains detailed information concerning the geology of a rapidly developing oil and gas field, and is intended to furnish information, chiefly of an economic character, in advance of the publication of the Iola folio.

Very respectfully,

C. W. HaYes,

Hon. Charles D. Walcott,

Geologist in Charge of Geology.

Director United States Geological Survey. 



\section{ECONOMIC GEOLOGY OF THE IOLA QUADRANGLE, KANSAS.}

By George I. Adams, Erasmes Haworth, and W. R. Crane.

\section{N T R O D U C I O N.}

By George I. Adams.

\section{IOCATION OF AREA DESCRIBED.}

The Iola quadrangle is a rectangular area situated in southeastern Kansas (see fig. 1), its eastern and southern limits lying respectively 20 and 35 miles from the borders of the State. It is bounded by meridians $95^{\circ}$ and $95^{\circ} 30^{\prime}$ west longitude, and $37^{\circ} 30^{\prime}$ and $38^{\circ}$ north latitude. It has an area of about 944 square miles and includes nearly all of Allen County, the north half of Neosho County, the west border of Bourbon County, and the northwest corner of Crawford County. The larger towns in the quadrangle are Iola and Chanute, the growth of which has recently been stimulated by the finding of oil and gas. Humboldt, which is situated between Chanute and Iola, and Laharpe and Gas, which lie to the east of Iola and are connected with it by an electric line, are also in the more productive belt of the oil and gas territory. The towns of Erie, Shaw, Savonburg, Elsmore, Bronson, and Moran are at approximately the.eastern limit of the field.

Although the Iola quadrangle is one of the arbitrary units employed for the purpose of mapping, its limits are fortunately situated with respect to the northern portion of the oil and gas field. It is purposed to continue the study of the oil and gas resources in this region, and for that reason the Independence quadrangle; which corners the Iola on the southwest, has already been surveyed topographically, and its geology is being studied. Those who are interested in oil and gas areas that do not fall within the Iola quadrangle may perhaps still be aided by this bulletin to a better understanding of the field in general, since the structure and general relations of the oil and gas are very similar in all parts of the Kansas-Indian Territory field as at present developed. 


\section{GENERAL STATEMENT.}

The field work upon which this report is based was done in August and early September, in 1903, the general supervision of the work being in charge of the writer. It was divided into three portions: Prof. Erasmus Haworth, of Kansas University, collected and collated the information for the portion relating to the economic development; Prof. W. R. Crane, of Kansas University, made observations upon the pressure and flow of gas, his conclusions in regard to the
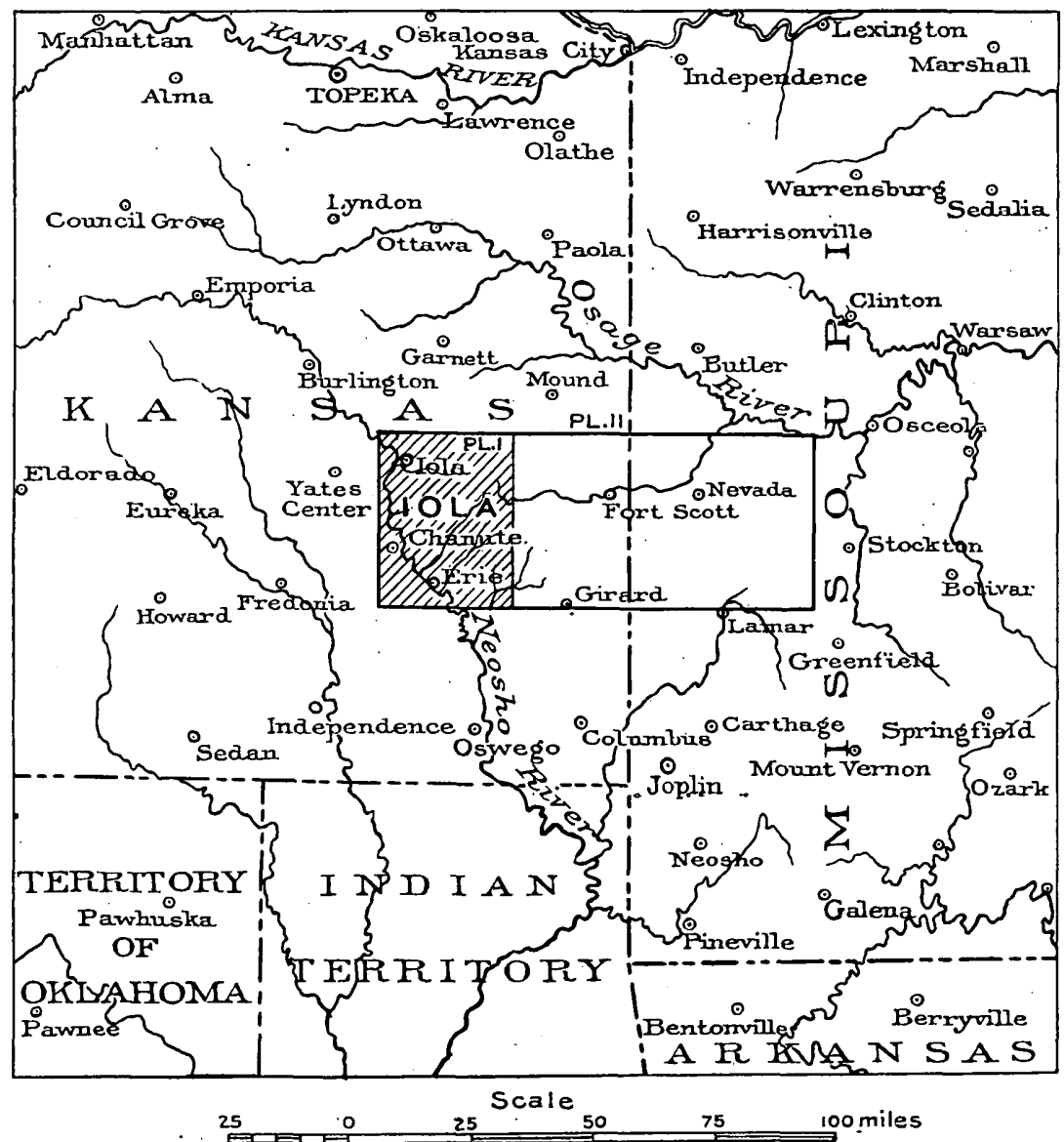

FIG. 1.-Sketch map showing location of Iola quadrangle (Pl. I) and area shown in Pl. II.

cause of the flow and the volume and approximate life of the wells in the field being presented in a separate chapter by him; and the writer, assisted by Mr. Millard K. Shaler, mapped the geologic formations and studied their structure and underground relations.

The Kansas oil and gas field has already been made the subject of several reports. The geology of this part of the State has been discussed by the university geological survey in volumes prepared under 
the direction of Professor Haworth, who has also written articles from time to time setting forth the available information pertaining to the economic development of the oil and gas resources of the State. In Bulletin $184^{a}$ of the United States Geological Survey the writer gave an account of the general geologic relations and economic development of the Kansas-Indian Territory field up to the summer of 1901. Although the rapid progress made in exploiting oil and gas has changed the area and importance of the producing localities, the data obtained through the drilling of numerous wells have verified the general statements and conclusions of that report, so that it is still of interest as a general discussion of the field as a whole. That being the case, this bulletin will be confined to the consideration of the Iola quadrangle.

The university geological survey of Kansas, under the direction of Professor Haworth, had a number of students in the field doing geologic mapping during the summer of 1903. As a result of their work and through the courtesy of that survey there is presented in this report a more detailed mapping of the Fort Scott quadrangle (see Pl. II and fig. 1), which lies directly east of the Iola quadrangle, than would otherwise be available. This is valuable in discussing the underground relations of the formations, since the rocks that are encountered in the lower portions of the wells outcrop to the east, beyond the limit of the Iola quadrangle.

a Adams, Geo. I., Oil and gas fields of the western interior and northern Texas coal measures and of the upper Cretaceous and Tertiary of the western Gulf coast: Bull. U. S. Geol: Survey No. 184, 1901. 


\section{GEOLOGY OF THE IOLA QUADRANGLE.}

By George I. Adams.

\section{SURFACE F'EATURES.}

The Iola quadrangle is situated in the prairie plains region, of which the eastern third of Kansas forms a portion. It has a moderate elevation, the lowest contour in the valley of Neosho River being 860 feet and in that of Marmaton River 880 feet above sea level, while the altitude of the higher points ranges from 1,000 to 1,080 feet. The surface features have been developed by erosion, and inasmuch as folding and faulting of the rocks are nowhere apparent, the topography is closely related to the strike and dip of the strata. The distinguishing features of this portion of the prairie plains are the low terraces and the occasional isolated hills or mounds.

The rock formations are interstratified shales, sundstones, and limestones, which have a northeast-southwest strike. As a result of erosion the harder and more resistant beds produce escarpments which follow, with many deviations, the strike of the rocks. Inasmuch as the limestones are relatively more resistant in this area, they are found outcropping at the top of the escarpments and on the dip slopes. The dip of the rocks is to the northwest and varies usually from 10 to 25 feet per mile. In traveling northwest, where the country is not much dissected by streams, and in ascending the moderate terraces, one passes over the surface outcrop of successively higher beds. In going beyond the line of a particular escarpment one may travel several miles upon the surface of the same formation if stream valleys do not interrupt it; may do so, in fact, until he approaches the foot of the succeeding terrace. Where the drainage has dissected the country, particularly along the larger streams and their tributaries, the observer will readily note the surface features which indicate the dip of the rocks, and will see that the hills and bluffs form parts of sinuous escarpments.

The geology of the area is simple (Pls. I and II) and the fact that the country is not covered with forests renders observation easy. The uniformity of the general features, however, makes difficult the study of the detailed geologic structure, since definite folds are nowhere found and irregularities are taken up by minor and varying dips of the rocks. 


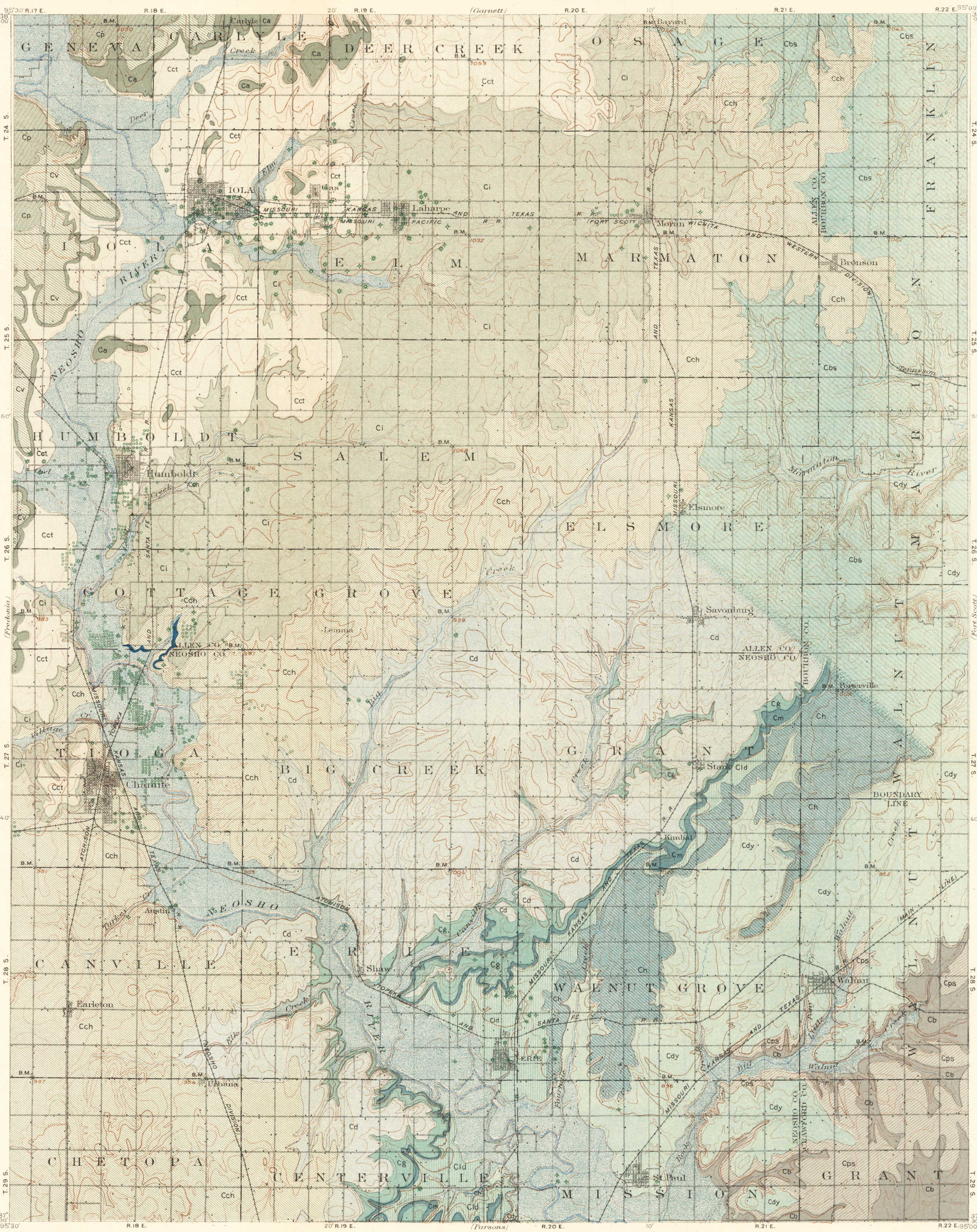


The rocks that outcrop in the Iola quadrangle and the oil and gas formations that are encountered in drilling (see Pl. III) belong to the Pennsylvanian series of the Carboniferous. This series is commonly spoken of as the Coal Measures, since it contains beds of workable coal, the important ones of which, in Kansas, are found in the lower portion of the section. Below the Coal Measures is the Boone limestone of the Mississippian series. In order to understand the relations of the strata below the surfece in the Iola quadrangle, it is necessary to describe the formations which outcrop to the east and which are shown on the accompanying map (PI. II).

\section{DESCRIPTION OF FORMATIONS.}

\section{MISSISSIPPIAN SERIES.}

Boome formation.-The Coal Measures rest upon the Mississippian series, which, in this region has commonly been designated the "Mississippian limestone" by those who have described or reported it in drill holes. The particular limestone formation spoken of under this name is in reality the Boone formation, which has its type locality in northern Arkansas. It outcrops over a large area in northern Arkansas, northeastern Indian Territory, and southeastern Missouri, and consists of limestone beds carrying a large amount of chert or flint, interbedded or occurring as rolls and lenses in it. In this formation are found the lead and zinc deposits around Joplin, Mo., and Galena, Kans. Within Kansas it outcrops in a small area between Spring River and the southeast corner of the State. Due east of the Iola quadrangle it is found in St. Clair, Cedar, and Dade counties in Missouri (see Pl. II).

The numerous wells that have been drilled in the Boone formation and the shafts and workings of mines, as well as the natural exposures of its outcrop, show that it is not an oil- and gas-bearing formation. In the oil and gas field this formation may be appropriately spoken of as the floor upon which the Coal Measures rest (see section accompanying Pl. II). It is encountered at a considerable depth in drilling, and when it is reached, as shown by the cuttings, drilling operations are usually stopped. A few wells within the oil and gas field have penetrated it for a considerable distance, notably a deep well at Neodesha, which probably passed entirely through it and into the underlying rocks. Its presence underneath the Coal Measures is pretty well established for the major portion of the field, and experience shows that there is no reason for expecting oil and gas after it has been reached.

The dip of the Mississippian limestone is to the northwest and, considered in its broader aspects, is even and regular. At certain places, however, the records of wells show that its upper surface is liable to present undulations and irregularities. 


\section{PENNSYLVANIAN SERIES.}

Cherokee shale.-Tue lowest formation of the Kansas section of the Coal Measures is known as the Cherokee shale and has a thickness of about 450 feet. Although the term shale is applied to it it contains beds of sandstone which are, in some localities, of considerable extent and thickness. The area of outcrop is approximately 30 miles wide, and extends from Missouri across the southeast corner of Kansas into Indian Territory. Although some oil and gas have been found in the higher formations the Cherokee shale contains the important reservoirs in the Kansas-Indian Territory field. Where it outcrops there are occasional oil seeps, or springs, and deposits of maltha, or heavy oil, which have resulted from the surface oxidation and evaporation of the petroleum. Oil in economic quantity is found where the Cherokee shales are under sufficient cover to seal in and retain their contents of oil and gas. The dip being northwest, the shales are carried underground, so that within the principal oil- and gas-producing belt their upper portion is encountered at a considerable depth. Within the Iola quadrangle this depth increases from southeast to northwest, and is equal to the thickness of the overlying beds.

The records of numerous drill holes bave been studied and from them it has been learned that the sandstone beds contained in these shales vary in character and thickness. In places they grade into more shaly material, so that it is impossible to identify the individual beds except in areas that have been closely drilled. Inasmuch as these sandstones are the principal oil and gas reservoirs close attention has been given to their character and extent. This subject will be discussed later in the report; here it is sufficient to state that no beds bave been found which can be identified and given special designations, as has been done in certain fields where the oil sands are numbered or named.

Fort Scott limestone. -This limestone is the lowest persistent formation in the Kansas section of the Coal Measures. It is named from the town of Fort Scott, where it outcrops. It there consists of a lower limestone member $4 \frac{1}{2}$ feet thick (the rock used for making -hydraulic cement at Fort Scott), and an upper limestone member from 10 to 14 feet in thickness, with usually a shaly member about 7 feet thick between the two. Although the Fort Scott limestone is a relatively thin formation it is easily traced in the field and has been identified from Fort Scott for a short distance northeast into Missouri and southwest into Indian Territory, its line of outcrop passing the towns of Girard, Cherokee, and Chetopa, Kans., and Chelsea, Claremore, and Catoosa, Ind. T. It lies just above the Cherokee shales and.in the Kansas oil and gas field may be spoken of as the last Coal Measures limestone encountered in the wells. 

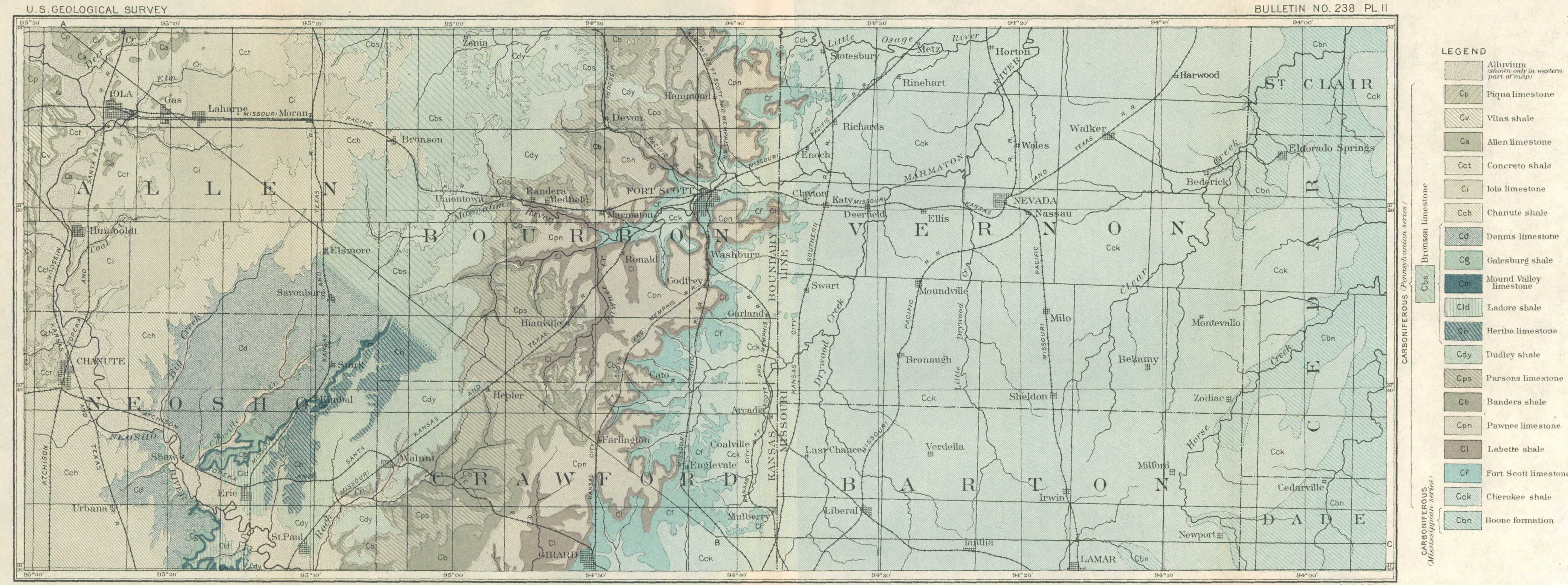

Farlingiton

(1)

GEOLOGIC MAP AND SECTION SHOWING STRUCTURAL RELATIONS OF THE OIL-AND GAS-BEARING FORMATIONS OF THE IOLA QUADRANGIE, KANSAS 
Labette shale. - The Labette shale lies above the Fort Scott limestone and varies in thickness from 30 to 60 feet. Its outcrop forms an irregular belt, limited by the Fort Scott limestone on the southeast and the Pawnee limestone on the northwest. The shale carries relatively little sandstone and there is nothing that serves to distinguish it especially from the other shales of the series.

Pawnee limestone. - The second limestone formation is the Pawnee, which, on Pawnee Creek west of Fort Scott, has a thickness of 35 feet. According to the records of wells it varies from 20 to 50 feet in thickness. Its outcrop is shown on Pl. II.

Banderc shale.-Succeeding the Pawnee limestone is a bed of shales approximately 100 feet thick at its outcrop on Marmaton River near Bandera. Its thickness varies, however, with its lateral extent. Near Bandera it contains considerable thin-bedded sandstone, which is quarried for flagging; southwestward near Farlington and Brazilton it is similar in character. Its outcrop is shown on Pls. 1 and II; it is the lowest formation outcropping within the Iola quadrangle (Pl. I).

Parsons limestone.-The third limestone formation, counting from the base upward, is known as the Parsons. limestone. Along Marmaton River it forms a bed 8 feet thick, but thickens southward. Within the Iola quadrangle it is found principally along Big and Little Walnut creeks, and on the higher ground to the southeast where it occupies irregular areas. Around Walnut and southward it has a thickness of from 10 to 15 feet and is regular in character.

Dudley shale.-Succeeding the Parsons limestone is the Dudley shale, with a thickness on Marmaton River of about 150 feet. It carries some sandstone and occasionally a thin layer of limestone. The outcrop of this formation is shown on Pls. I and II. This shale outcrops principally in stream valleys and occupies an irregular belt along Rock and Walnut creeks. Since it consists of soft beds and is easily eroded its upper limit and western border are defined by an escarpment which is quite conspicuous and in which occurs the succeeding limestone formation.

Bronson formation. - In the northeastern part of the Iola quadrangle, succeeding the Dudley shale, is a heavy limestone formation which has a thickness of from. 60 to 80 feet. Its western outcrop forms a conspicuous escarpment along the head of Marmaton River. It consists of five members (see Pl. III). The lowest of these is an unevenly and heavily bedded limestone from 20 to 25 feet thick; succeeding this is a bed of shale, seldom more than 7 feet in thickness; next comes a middle member of limestone beds with some shale layers, aggregating about 20 feet where it is thickest; above this is a shaly member which grades into sandstones and has an average thickness of about 10 feet; the top member consists of limestones, the upper layer

Bull. 238-04-2 
of which is in places a cross-bedded oolite, with an average thickness of 25 feet.

The detailed section of the Bronson formation varies from place to place as the character of the bedding of the limestone changes and as the shale members thicken and thin. These are so thin and inconspicuous in the northern part of their outcrop that they can not be mapped; they thicken southward, however, and become important enough to merit separate designation. On the geologic map of the Iola quadrangle (Pl. I) it will be seen that the pattern by which the Bronson is indicated is blended along a line extending approximately from Elsmore through Porterville, south of which five formations are shown as its equivalent. There are the Hertha limestone, Galesburg shale, Dennis limestone, Cherryvale shale, and Drum limestone, which are described below.

The Bronson limestone carries a large amount of chert in certain of its beds, and this, weathering out on the surface, forms the so-called flints which are found within the area of its outcrop. The surface of the country occupied by this formation is stony, the rocks protruding through the thin soil as bowlders. This is one of the heaviest limestone formations encountered in drilling for oil and gas in the northwestern part of the quadrangle, and is sometimes spoken of by the drillers as the 60 -foot lime, no account being taken by them of the thin shale members which occur in it.

Hertha limestone.-This formation, which is named from the station of Hertha, just south of the border of the Iola quadrangle, has a thickness of about 10 feet at the type locality, thickening to the north. The eastern border of its outcrop forms a prominent escarpment to the northwest of Walnut, where it is found on a long ridge and has a thickness of as much as 20 feet.

Galesburg shale.-The northernmost point at which this formation is mapped is in the vicinity of Porterville. It increases in importance to the south, and has a thickness of about 40 feet along Neosho River and on the southern border of the quadrangle. Inasmuch as it is easily eroded the surface in that locality is cut down into an even plain, which blends with the alluvium along Neosho River. The town of Erie is located on it.

Dennis limestone.-This formation, which is equivalent to the middle member of the Bronson, thins somewhat to the south, having a thickness of only about 10 feet on the border of the quadrangle. North of Erie its outcrop occupies a very narrow belt, and as it usually occurs on a slope, is somewhat disguised by soil and detrital material.

Cherryvale shale.-This formation, although designated as a shale, carries some sandstone, especially in its lower portion. It thickens southward, the shale of the upper part becoming more important; 


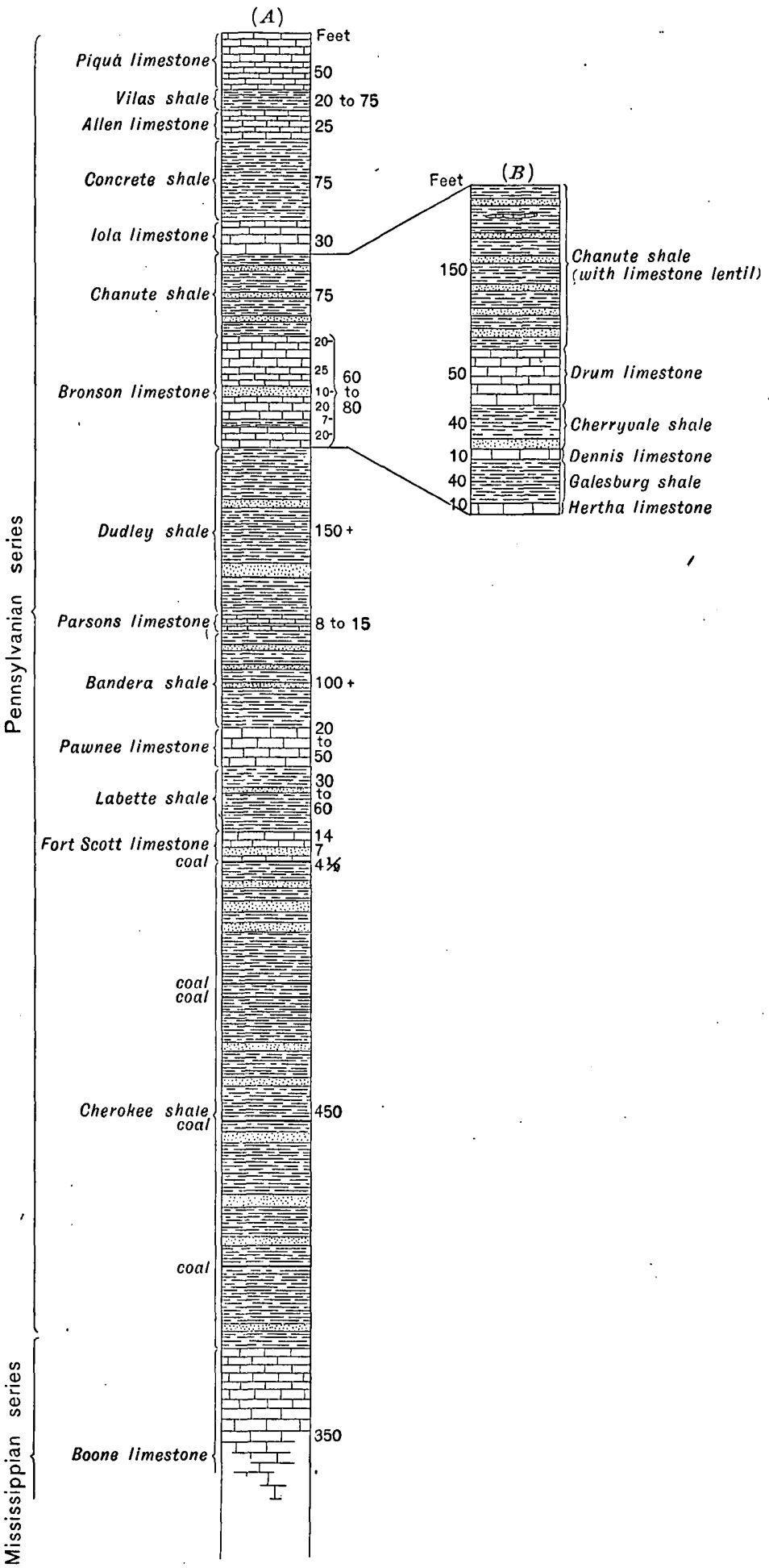

GENERAL SECTION OF ROCKS EXPOSED IN THE IOLA QUADRANGLE AND ENCOUNTERED IN DRILLING. 
at the southern border of the quadrangle it has a thickness of about 41 feet.

Drum limestone.-This formation, which is equivalent to the bighest member of the Bronson limestone, outcrops with its maximum thickness in a wide belt in the central part of the Iola quadrangle. At Shaw the limestone is as much as 50 feet in thickness, thinning gradually from there southward. It is the surface formation along Big Creek and in the upper valley of Canville Creek; where it is weathered the surface is stony and bowldery. The Drum limestone carries a large amount of flint in its lower portion; the upper portion is an oolite which exhibits cross-bedding and false bedding, and attains a thickness in some places of as much as 15 feet.

In the northern portion of the quadrangle the 60 -foot lime, spoken of by the well drillers, is the Bronson. In the southern portion of the quadrangle the Drum limestone is the one commonly referred to by this name, the Hertha and Dennis limestones being relatively thin and separated by the Galesburg and Cherryvale shales.

Chanute shale.-This formation, which succeeds the Bronson limestone in the northern and the Drum limestone in the southern part of the quadrangle, outcrops in a conspicuous belt extending from northeast to southwest. Although the rock section consists chiefly of shale, it carries a large amount of sandstone, and as this weathers out in ledges and on disintegration gives rise to sand, the country in which the formation occurs is generally sandy. The Chanute shale in the vicinity of Bayard; on the northern border of the quadrangle, is about 75 feet thick. In the southeastern part of the quadrangle it is about 150 feet thick and the belt occupied by it is correspondingly wide.

There are occasional outcrops of thin limestone beds in the Chanute shale which appear to occur in the upper part of the formation. Possibly they belong to a rather definite horizon, but the outcrops could not be connected in the field. Along the creek which crosses the Allen County-Neosho County line north of Chanute, is a bed of limestone which has a thickness of about 7 feet and which is mapped as a lens in the Chanute shale. It should be considered as of only local importance in the stratigraphy.

Iola limestone.-The thickness of this bed at Iola is 30 feet. It occur's as a massive-bedded limestone, and is the one which is quarried for making Portland cement. The principal area of .its outcrop extends from Laharpe and Moran southwest to Humboldt and Chanute. Within this area it is covered by a variable thickness of soil, which frequently disappears, leaving the formation exposed and making the surface of the country stony. Along the eastern side of Neosho River, at Humboldt, it forms a high bluff in which practically its whole thickness is exposed.

This formation, like all the others described, dips to the northwest. 
Its southeast border forms a divide between Big Creek and the headwaters of the Marmaton drainage on the one side, and the streams which are tributary to the Neosho from the east, above Chanute, on the other. On the upper surface of the limestone a dip slope is developed, which is well brought out by the contours of the topographic map. On Rock and Coal creeks there are inliers of the Chanute shale where the Iola limestone has been cut through. It is not unlikely that along some of the smaller streams and ravines erosion has also cut through the Iola at many places, but the Chanute shale is not seen because of the covering of soil on it. In drilling wells in the area which is mapped as the Iola formation, at many places only a few feet of the limestone are encountered, and in some cases it is found to be absent. This, as has just been explained, is due to erosion.

Concreto shale.-Succeeding the Iola limestone is a bed of shale having a thickness of about 75 feet. It is uniformly a clay shale, and accordingly is suitable for the manufacture of brick, and, with the admixture of limestone, for Portland cement, for which it is used at Iola and at the small manufacturing town of Concreto, north of the town of Gas. . Within the area of its outcrop are a number of mounds formed of this shale and capped with the succeeding limestone formation. The western border of the valley of Neosho River, from the vicinity of Iola southward to a point below Humboldt, lies on this shale, and the alluvium along the streams blends with the outcrop of the shale to the west in a somewhat indefinite way.

Allen limestone. - In the vicinity of Carlyle this limestone formation has a thickness of about 25 feet. It thins. to the south gradually, so that it has a thickness of about 10 to 15 feet along the western border of the quadrangle. Its outcrop forms a narrow belt west of Neosho River. It is difficult to trace at many places, but its position has been determined by studying the records of wells. A number of irregular areas of this formation occur to the east of Neosho River, capping hills and mounds.

Vilas shale. - The type locality of this formation is at Vilas, where the shale has a thickness of about 75. feet. This formation, which has previously been wrongly correlated, is now known to lie between the Allen limestone and the Piqua limestone, which latter formation is described below. The Vilas shale thins somewhat to the north, so that near the northern portion of the quadrangle it is not more than 20 feet thick.

Piqua limestone.-This is the highest formation exposed within the Iola quadrangle. It consists of heary-bedded limestones, having a total thickness of about 50 feet. It occurs only in the northeast corner of the quadrangle, but beyond the area here described outcrops conspicuously for long distances to the northeast and southwest. It was traced to the vicinity of Vilas, at which place it overlies the Vilas shale. 


\section{ALLUVIUM.}

Along the valley of Neosho River and the larger streams which are tributary to it is a belt of alluvium deposited by the overflow of the streams during flood time. It consists of river silts derived from the limestones, shales, and sandstones which are crossed by the streams, and is rich agricultural land.

From the vicinity of Chanute southward dikes have been constructed to prevent the overflow of the river and thus render the land available for farming. The alluvium along the creeks is not of much importance. -There are, however, small fields which have an alluvial soil, and in some portions of the quadrangle where alluvium is not mapped there are small areas of it which are cultivated.

The cherts of the limestones upon disintegration give rise to gravel, which is found mixed with the soil near the ledges of rock from which it is derived and at places where the limestones have entirely wasted away. These gravels have also been transported by the streams and deposited in beds. These are not of much importance outside of certain gravel bars along Neosho River, which have been utilized for grading roads. The main street of Humboldt has been macadamized with this material.

\section{CORRELATION AND CORRECTION OF FAUNAT LISTS.}

The mapping accompanying this report is regarded as the first systematic detailed work in the region, and accordingly the formation names used are such as can be applied without involving correlations with distant localities. This has made it necessary to give new names to some formations which have been previously described. Some errors in correlation, discovered in former work, have been corrected in this bulletin and the faunal lists of certain of the formations revised accordingly.

In Bulletin No. $211^{a}$ of the United States Geological Survey a section of the Carboniferous of eastern Kansas is given in detail. The changes in nomenclature which have arisen since that bulletin was issued are as follows: In the northern part of the quadrangle the Hertha, Galesburg, Dennis, Cherryvale, and Drum formations are mapped as a single formation under the name Bronson limestone, for which the preoccupied name Erie bad been previously used. The Earlton limestone has been found to be the equivalent of the Iola limestone and the name Earlton is accordingly dropped; the shale previously described as the Lane shale is called the Concreto shale; the Stanton limestone is called the Allen limestone. The Vilas shale at the type locality has been found to be above the Allen limestone;

a Adams, Girty, and White, Stratigraphy and paleontology of Upper Carboniferous rocks of Kansas section: Bull. U. S. Geol. Survey No. 211, 1903. 
this name is retained, and the position of the formation in the section is accordingly corrected. The limestone which occurs above the Vilas shale is found to be a new limestone formation to which the name Piqua is given. The error in correlation of this outcrop, as well as the error in tracing the Earlton limestone, was due to the fact that the relatively broad valley of Neosho River made the reconnaissance. mapping difficult. The following columnar section is the one used in this bulletin .

Formations exposed in, Iola quadrangle.

Alluvium.

Piqua limestone.

Vilas shale.

Allen limestone.

Concreto shale.

Iola limestone.

Chanute shale.

Drum limestone.

Cherryvale shale.

Dennis limestone.

Bronson formation.

Galesburg shale.

Hertha limestone.

Dudley shale.

Parsons limestone.

Bandera shale.

Pawnee limestone.

Labette shale.

Fort Scott limestone.

Cherokee shale.

The corrected faunal list of the Iola limestone as now known is as follows:

\section{Fossils found in. Tola limestone.}

Eupachycrinus sp.

Fistulipora sp.

Fenestella sp.

Chonetes flemingi.

Productus cora.

Productus punctatus.

Marginifera wabashensis.
Spirifer cameratus.

Spiriferina kentuckyensis.

Seminula subtilita.

Dielasma bovidens.

Aviculopecten interlineatus.

Phanerotrema grayvillense.

The corrected faunal list of the Allen limestone as now known is as follows:

Irossils found in Allen limestone.

Lophophyllum westi.

Eupachycrinus sp.

Arch:eocidaris sp.

Polypora sp.

Fenestella sp.

Fistulipora sp.

Rhipidomella pecosi.

Enteletes hemiplicatus.
Orthotetes crassus.

Chonetes flemingi.

Productus nebraskensis.

Productus punctatus.

Marginifera wabashensis.

Spirifer cameratus.

Squamularia perplexa.

Spiriferina kentuckyensis. 
Seminula subtilita.

Hustedia mormoni.

Pugnax utah.

Dielasma bovidens.
Platyceras nebraskense.

Bellerophon sp.

Phillipsia major.

The corrected faunal list of the Piqua limestone as now known is as follows:

\section{Fossils found in Piqua limestone.}

Triticites secalicus.

Lophophyllum westi.

Lophophyllum proliferum.

Chsetetes milleporaceus.

Eupachycrinus sp.

Septopora sp.

Fenestella sp.

Polypora sp.

Fistulipora sp.

Crania sp.

Rhipidomella pecosi.

Enteletes hemiplicatus.

Orthotetes crassus.

Meekella striaticostata.

Meekella pyramidalis?

Chonetes flemingi.

Productus semireticulatus.

Productus cora.

Productus punctatus.

Productus nebraskensis.
Productus ef. subhorridus.

Productus sp.

Marginifera wabashensis.

Proboscidella sp.

Spirifer cameratis.

Squamularia perplexa.

Spiriferina kentuckyensis.

Seminula subtilita.

Dielasma bovidens.

Myalina subquadrata.

Myalina swallowi.

Pseudomonotis equistriata.

Schizodus sp.

Leda? sp.

Soleniscus ponderosus?

Naticopsis sp.

Euconospira sp.

Pleurotomaria? sp.

Nautilus sp.

Leperditia sp.

\section{GENERAI STRUCTURE.}

The general structure of the rocks of the Iola quadrangle may be best explained by the horizontal section accompanying PI. II. The dip of the rocks is to the north-northwest, and accordingly the portion of the section along the line $A-B$ is approximately parallel with the dip. It will be seen by reference to the section that the wells at Iola and Laharpe penetrate a considerable thickness of interstratified limestones, sandstones, and shales before reaching the Cherokee shale, which contains the important reservoirs of oil and gas. The wells in the vicinity of Elsmore encountered a somewhat smaller thickness of these rocks, and the drill holes at Hepler and in the vicinity of Farlington reached the Cherokee shale at a relatively small depth. The outcrop of the Cherokee shale is farther to the east and occupies a wide belt of country. Along the eastern border of the map (PI. II.) the outcrop of the Boone formation is shown; in the section its extension underneath the Cherokee shale to the west and northwest is indicated. Its position underground has been learned from the record of deep wells which have been drilled through the Cherokee shale without encountering oil and gas, and its upper surface is known to form a rather even floor, on which the Coal Measures rest. In Pl. IV two 
sections are shown, which are constructed from the records of wells and the surface outcrops of the formations. The section through Moran, Laharpe, and Iola extends east and west in the northern part of the quadrangle, and the section through Erie, Shaw, and Chanute extends from southeast to northwest in the southern part of the quadrangle. In these sections the limestones are indicated by conventional patterns; the intermediate spaces are the horizons of the shales. In these sections, although the vertical exaggeration is very considerable, no anticlines or synclines appear. The degree of dip which was observed in the field varies from place to place in such an irregular: manner that the local variations are not apparent in the sections. The amount of dip may be stated to vary from 10 to 25 feet per mile. The limestones are not exactly parallel with each other, this being due to the irregular thinning and thickening of the shale beds. Certain of the well sections record a greater number of limestones than there are limestone formations in the general section. The Bronson limestone, when followed south through the quadrangle (see Pls. I and II), is. found to split up into three distinct limestone formations, with intervening shale beds, which are important enough to map. This variation in lithology occurs along the strike. It is altogether probable that, if the limestones could be studied along their dip in their extent underground to the west, some of them would be found to split up in a similar manner, at least locally, and when in drilling more limestones are encountered than are recorded in a general section it is probable that the extra ones are due to such variations in sedimentation.

It will be remembered that in describing the Chanute shale a limestone lens of sufficient importance to be shown on the geologic map was mentioned as occurring in its upper part. Similar lenses no doubt occur in this and other shale formations in their underground portions, and accordingly the finding of thin limestones at unusual horizons is not surprising.

\section{ORIGIN OF OIL AND GAS.}

The processes by which oil and gas are formed in nature are not fully understood: Two hypotheses, known as the organic and inorganic theories, have been advanced. In the Kansas field the facts support the organic theory, which is the one usually accepted by geologists who have studied the relations of oil and gas.

The rocks which are encountered in drilling in the Kansas field, especially the shales, contain large amounts of carbonaceous matter of animal and vegetable origin that was deposited at the time the sediments were laid down. This material is present in sufficient quantity to have given rise to the oil and gas through the processes of decomposition and the physical and chemical changes to which it has been subjected during geologic time. When once formed the products of 


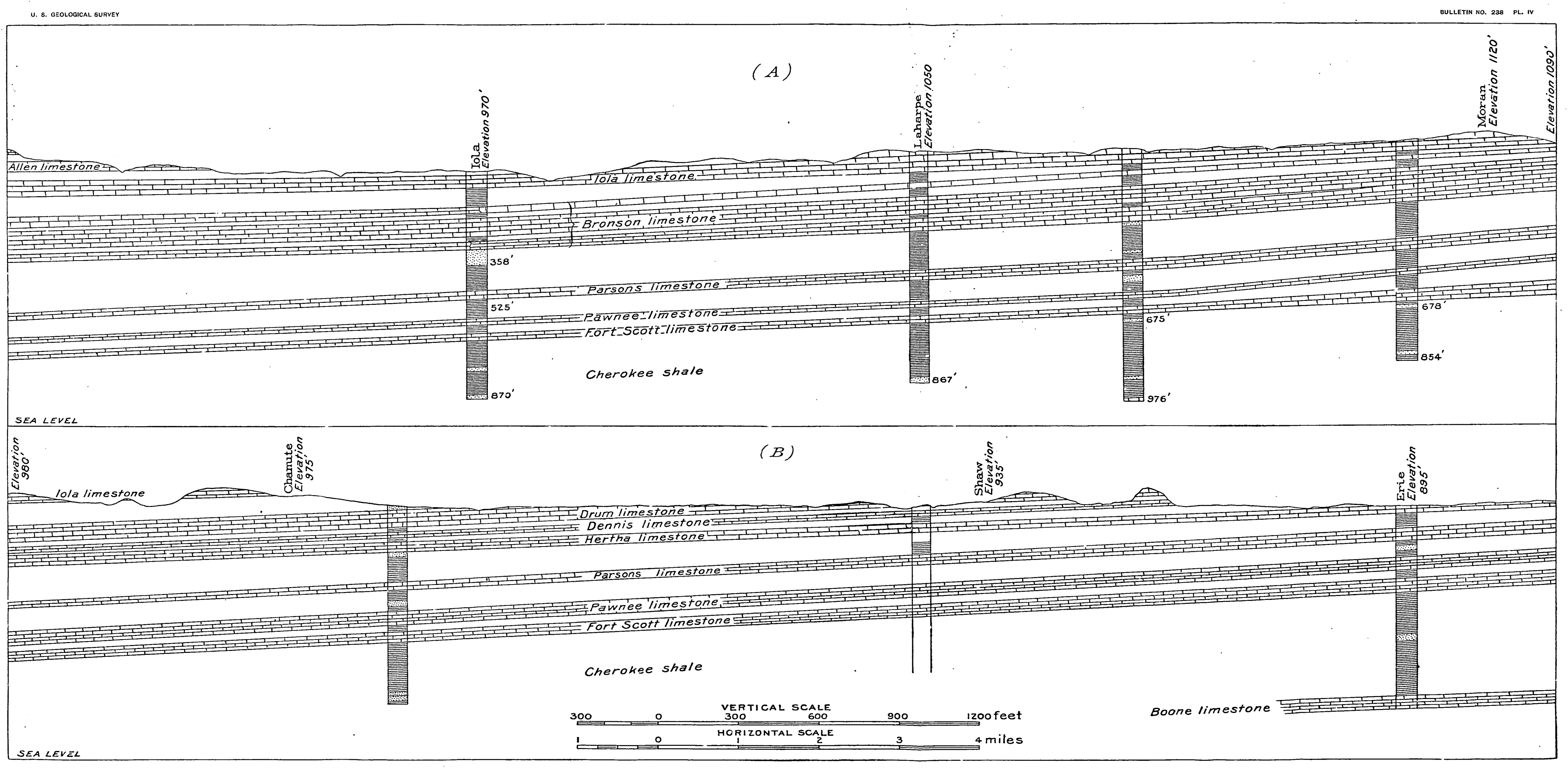

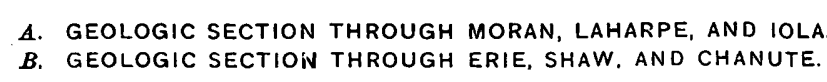


decomposition probably migrated into the more porous rocks, especially into the sandstones, in which they are now found. No doubt. a large amount of the oil and gas has escaped from the formations where these outcrop at the surface. The economic bodies are those which are completely sealed in by impervious shales with which the sandstones are interbedded. There are no surface indications of oil and gas in the more productive portion of the field. The Cherokee shale, which contains most of the oil and gas sands, outcrops along the eastern border of Kansas and in Missouri, where there are occasional seeps of gas, oil, and maltha, the latter being a heavy residual from oil. These seeps have attracted the attention of prospectors and some drilling has been done near them, but, inasmuch as they occur where the rocks outcrop, no large bodies of oil or gas have been discovered in their vicinity.

The question of the movement of oil and gas is one which is not well understood. It is generally believed, however, that where oil, gas, and water are found in a given stratum, the oil and gas will move upward with the dip of the rocks until they enter a pocket or. escape to the surface. In the Iola quadrangle the oil and gas sands are of local extent and are interbedded with the shale in such a way that where they are deeply buried they form perfect reservoirs. The dip of the formations is to the northwest. Accordingly the oil and gas 'may be expected in the higher or southeastern extension of the sandstone beds; the heavier salt water will border these deposits on the northwest. These conditions, though somewhat ideal, are found in many places, and variations from them are due probably to slight irregularities in the dip of the rocks and to changes in the character of the sediments which bring in unknown and undeterminable factors. The upper margin of an inclined or dipping sandstone is the simplest form of reservoir and no doubt is the common one in the Kansas field (see fig. $6, A$, p. 46). In other fields the accumulation of oil and gas is determined by folds, or synclines and anticlines, as they are usually called. These may occur locally in the Kansas field, but it has been impossible to locate definitely any anticlines or upward archings of the oil- and gas-bearing strata.

\section{RELATIONS OF THE OIL- AND GAS-BEARING SANDSTONES.}

Inasmuch as the oil and gas reservoirs are in the sandstones interbedded with the shales, the question arises as to whether these sandstone beds form definite horizons. Well drillers and prospectors who have had experience in the Pennsylvania oil and gas field, on coming into the Kansas oil and gas field have attempted to name or number the producing sands and to identify them throughout the field. As will be seen from the following discussion this can not be 
done because of the very irregular and local character of the sandstone beds.

The principal reservoirs of oil and gas are in the Cherokee shale. This formation has been studied along the eastern border of Kansas where it outcrops, and it has been found that the sandstones in it vary in their lateral extent and in many cases are of very limited occurrence. Sometimes they grade into shales when followed along their outcrop, so that a bed which is sandstone at one place is a shale at another. The same variation that is found along the strike may be expected along the dip, and accordingly the Cherokee shale, where it occurs underground and is encountered in drilling wells, shows such variation in lithology that no definite sandstone horizons can be differentiated.

Fig. 2 is an ideal sketch of the relation of sandstones contained in a shale formation. In this figure the sandstone lettered $a$ is lenticular in shape, it thins out and disappears entirely from the section, and has no equivalent. The sandstone lettered $b$ is shown to grade over into a shale which is its equivalent. Sandstone $a$ is apparently

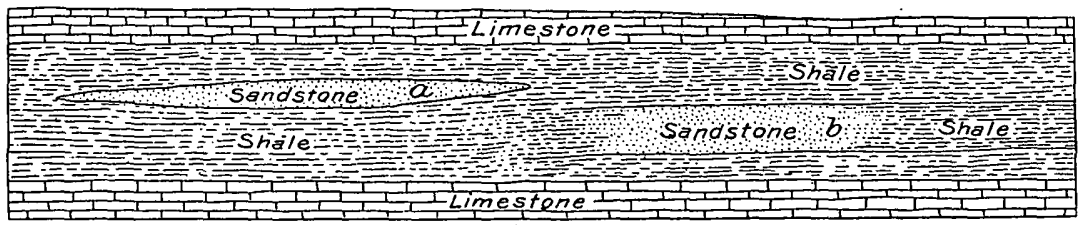

FỊG. 2.-Sketch illustrating disappearance of sandstone beds; $a$ is a lenticular sandstone which disappears by thinning; $b$ is $a$ sandstone which grades into shale.

the result of sedimentation at a time when only sand was being deposited. Sandstone $b$ apparently represents a period of sedimentation in which both sands and muds were being laid down, according to the local variation in the strength of the currents which assorted the material. As regards these two classes of sandstones, observations have shown that the lens-like beds are apt to be more persistent and to extend for longer distances, while the sandstones which grade into shales vary from place to place in an exceedingly irregular way.

The irregular area of the sands encountered in drilling may be shown by the following instances: In fig. 3 , the relative positions of certain wells are sketched and a portion of the record of each is shown drawn to scale. The wells are in secs. 26 and 27 , T. 26 S., R. 18 E., about 4 miles southeast of Humboldt. The wells in sec. 26 belong to the Oread Oil and Gas Company and those in sec. 27 to the Kansas Crude Oil Company. The well called Kansas Crude No. 1 was drilled to a total depth of 880 feet. At 768 feet, 10 feet of sand was found which was practically barren of oil. At 833 feet, 5 feet of sand. was found which was rich in oil, and at 844 feet, 12 feet of sand was encountered that was productive. The base of this sand was at 856 feet. 
Below this point 16 feet of shale was passed through, then 5 feet of sand, which produced close to 1 million feet of gas per day. The drill went 3 feet farther in light-gray shale and was then stopped.

Oread well No. 1 is situated 300 feet due east of the well just described. In it 8 feet of sand rich in oil was encountered at 764 feet, corresponding fairy well with the 10 feet of sand in the Kansus Crude well. Below it 62 feet of shale was passed through and then 14 feet of productive oil sand, corresponding very well with the 12 -foot bed of sand in the first well described. After passing 9 feet in shale the drill was stopped, as it was not desired to reach the gas which; according to the record of the Kansas Crude well, might be expected below.

Oread well No. 2 was located 400 feet south of Oread No. 1. At a depth of 798 feet 25 feet of sand was found which produced a large
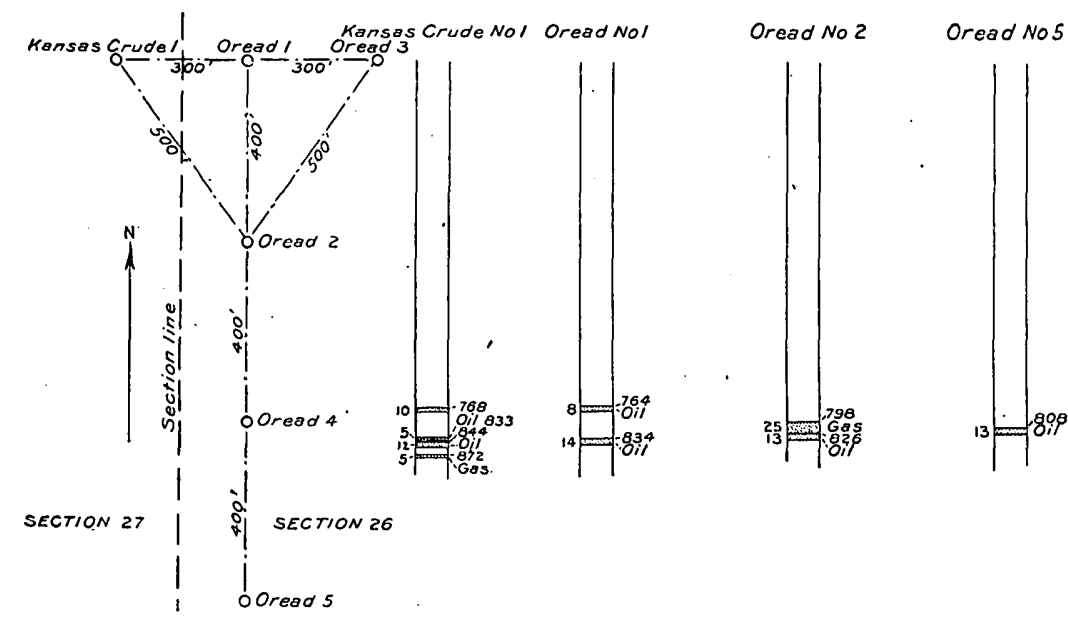

FIc. 3.-Relative positions and partial logs of certain wells of the Kansas Crude Oil and the Orend Oil und Gas compunies.

quantity of gas. Below this 4 feet of black shale, partly saturated with oil, was passed through, and then 13 feet of productive oil sand, the bottom of which was 839 feet below the surface. It will be noted that in this well no sandstone was found at a depth of 770 feet where, according to the records of the other wells, it might have been expected, while a bed of gas-bearing sand 25 feet thick was encountered at 798 feet, no trace of which was found in either of the other two wells.

The next well drilled was Oread No. 3, which was located 300 feet east of Oread No. 1. In it no oil was found, but a strong flow of gas was obtained from a sand at a depth of about 800 feet, doubtless cor. responding to the gas sand found in well No. 2.

Well No. 4 was located 400 feet south of No. 2. In it a productive oil sand was reached at 835 feet, corresponding to the oil sand in the other three wells. 
Well No. 5 was located 400 feet south of well No. 4 . At 800 feet a small flow of gas was obtained, and at 808 feet 13 feet of productive oil sand was encountered, corresponding with the oil sands in the other wells.

Reviewing what has been stated concerning these six wells it is seen that there is a sandstone 10 feet in thickness in Kansas Crude No. 1 , which disappears entirely in a distance of less than 600 feet to the east, and less than 500 feet to the southeast, as it is totally wanting in Oread Nos. 2 and 3. The 25-foot gas sand in Oread No. 2 is not represented in Oread No. 1, or in the Kansas Crude No. 1. This illustrates the rapid transition in the character of the strata.

In regard to the gas horizons it will be noted that a strong flow of gas was obtained from a sand lying beneath an oil sand in Kansas Crude No. 1, and that the stronger flow of gas was obtained from a sand above the oil sand in Oread No. 2, only 500 feet away. It is impossible to say what would have developed in Oread No. 3 had the drill gone deeper, but the main oil sand might have been reached. Likewise, it is impossible to determine whether the Oread wells, if they had been drilled deeper, would have reached the gas at 875 feet, the depth at which it was encountered in Kansas Crude No. 1.

The discussion of the records of the wells in sections 32 and 33 in T. 26 S., R. 18 E., in the valley of Neosho River between Humboldt and Chanute, furnish further illustration of the variation in the horizon and lateral extent of the oil and gas sands. In SE. $\frac{1}{4}$ sec. 32, the Kansas and Texas Oil Company drilled a dry hole. Later they completely surrounded this well with others not more than 350 feet away, all of which were producing oil wells. Some wells not more than 500 feet distant had an initial production of 300 barrels per day. In SW. $\frac{1}{4}$ sec. 33, which is adjacent, a large number of good oil wells were found with a gas well but a few hundred feet away.

In Neosho River Valley, east of Chanute, the oil is generally, but not always, above the gas. In most instances the oil sand is reached at from 700 to 750 feet. Usually there is a bed of shale about 40 feet thick below the oil sand, and beneath this a heavy bed of sand carrying large quantities of gas. The first gas wells at Chanute went through the oil sands, and it was their showing of oil that induced Mr. Knapp to begin drilling for oil in the Chanute field. The gas wells there had an initial capacity of from 1,000,000 to 4,000,000 cubic feet per day, and others recently drilled a mile or more to the east across the river had an even greater initial flow. From the sandstone, only 40 feet above this large volume of gas, oil was produced having so little gas with it that the pressure was not sufficient to cause the wells to flow, thus showing conclusively that there is no communication between the two sands.

In the east side of the W. $\frac{1}{2} \mathrm{SW} . \frac{1}{4}$ sec. 22, T. $27 \mathrm{~S} .$, R. $18 \mathrm{E}$., in 
U. S. GEOLOGICAL SURVEY

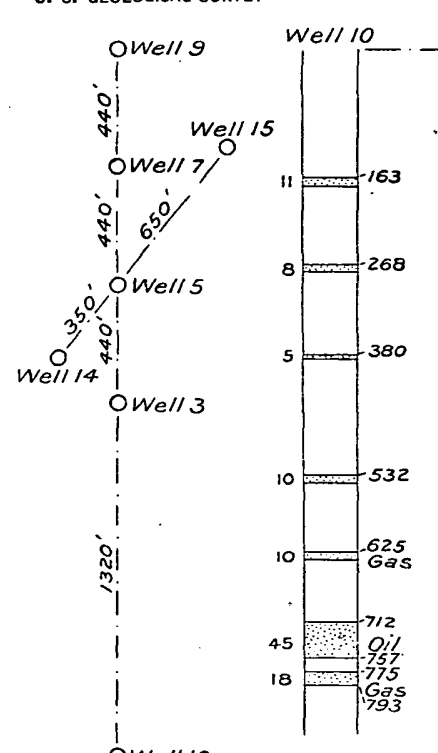

BULLETIN NO. $238^{\circ}$ "PL,
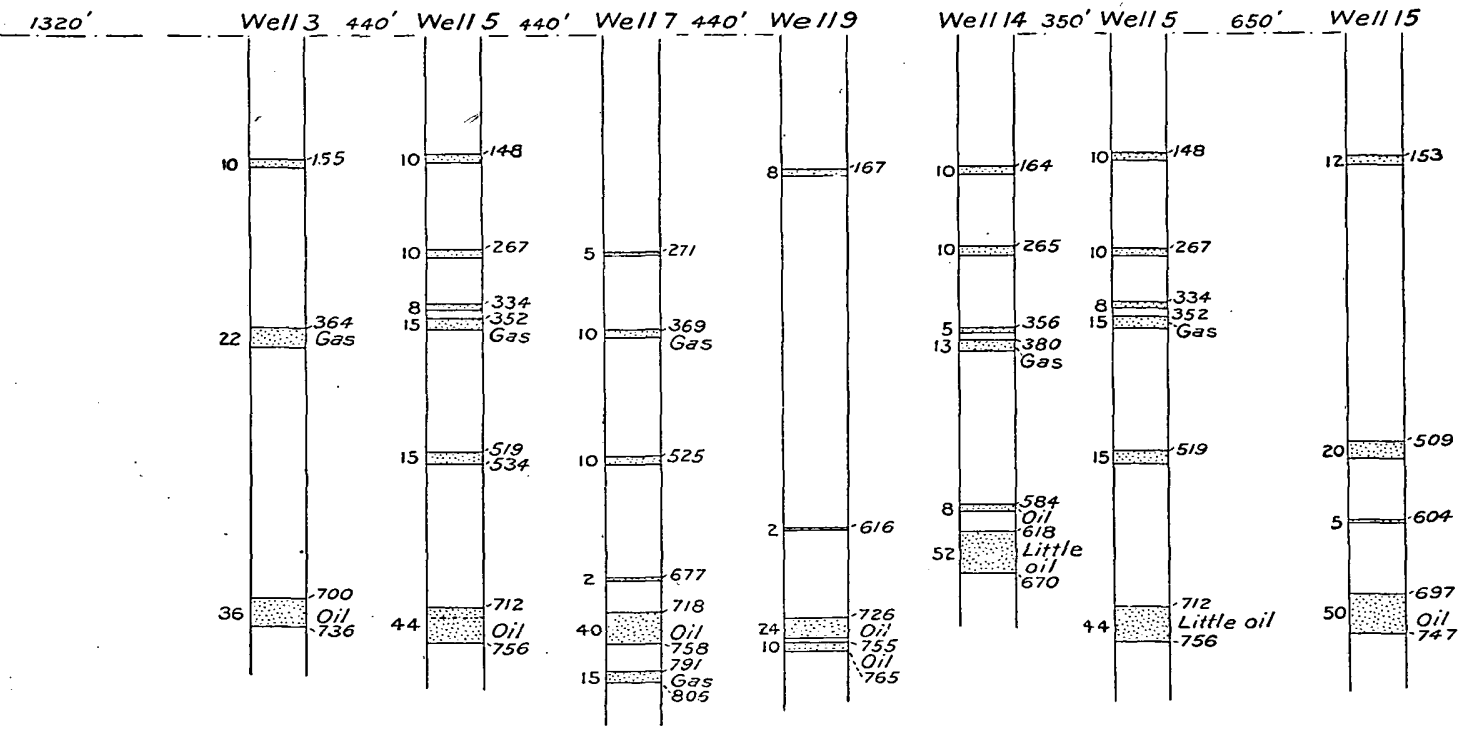

RELATIVE POSITIONS AND PARTIAL LOGS OF WELLS JUST EAST OF CHANUTE, KANS. 
the river valley just east of Chanute, Mr. Knapp drilled five wells on a north-south line. The records of these wells were carefully kept, as were the records of two wells, one on either side of this line (see Pl. V). The lower portions of the logs of these wells, showing the sandstones encountered, are presented, drawn to a scale, in Pl. V. The relative distance between the wells is indicated on the diagram and in the arrangement of the well sections. The surface is almost level, as the wells are in Neosho Valley, where the slope is not more than 2 or 3 feet to the mile. A glance at Pl. V will show the irregularity in the horizons at which the sands were encountered. In some cases the records of adjacent wells correspond closely in regard to particular sands, but it will be noted that some of the sands which are well marked in certain wells are wholly absent in others.

Inasmuch as the information is presented graphically, it is not discussed here. However, it leads to the conclusion that the individual sands are irregular in extent and character, and that they are exceedingly variable in regard to their contents of oil and gas. When both oil and gas are found in the same well the gas-bearing sand may be above or below the oil. Gas is generally more abundant than oil and has been found in a larger number of places; there are also usually more gas sands than oil sands in individual wells. 


\section{MINERAL RESOURCES AND THEIR UTILIZA- TION.}

By Erasmus Haworth and George I. Adams.

OIL AND GAS.

HISTORICAL.

Iola and Laharpe.-The first prospecting for oil and gas within the Iola quadrangle was done at Iola in 1873 , by Colonel Acers, who had a well drilled with a diamond drill to a depth of 737 feet. It produced a small amount of gas and also salt water. The water was conveyed into a building used for a sanitarium, which the gas; imperfectly separated, was used in part to light. Shortly after this a local company, consisting principally of the leading business men of Iola, was formed to drill for gas. It was regularly incorporated under the laws of Kansas, and obtained a charter from the city of Iola permitting it to pipe the city for the distribution of natural gas for public and private uses.

The first well, located in the river valley west of town, reached a depth of nearly 1,000 feet, but produced only a small amount of gas. The second well, which was near the main road leading west from Iola and not far from Neosho River, found a little gas, but not enough to be of very much importance. A third well, drilled a short distance southeast of where the Lanyon zinc smelter now stands, proved to be the best obtained up to that time, yielding a flow of 750,000 cubic feet of gas per day. Unfortunately it was drilled a little too deep, -striking a large amount of salt water which rendered it almost useless. After drilling a fourth well with similar ill success the company sold its leases and franchise to Messrs. Paullin and Pryor, who assumed all the contracts of the old company.

The new owners drilled their first well just south of the Northrup lumber yard, on the south side of Madison street near the Sante $\mathrm{Fe}$ right of way. This was followed by three other wells in the southwest part of the city. The last one, finished in December, 1893, obtained a strong flow of gas, and is the only well of the first eight drilled at Iola which produced gas enough to pay for the drilling. A period of twenty years was covered by this prospecting and many thousands of dollars were spent, but success was finally attained. 
One of the most interesting points in connection with the development of oil and gas in Kansas, not only in the Iola quadrangle, but elsewhere as well, is the very remarkable fact that in almost every instance the first prospecting was practically a failure and extended along through a number of years, to be followed by the work of new companies whose efforts were more successful. Messrs. Paullin and Pryor, however, were successsful before they sold out. They drilled another well in 1895, obtaining a large flow of gas which at once gave Iola prestige as a gas-supplied city.

About this time a new company, known as the Iola Cooperative Gas Company, drilled a well southeast of the city, which developed into one of the strongest wells in the entire lola field. The company piped its gas into the city and placed it upon the market. Litigation at once sprang up between it and Paullin and Pryor, who claimed to have an exclusive franchise. The final outcome was that Messrs. Paullin and Pryor sold out to the new company in 1898, and the two properties were consolidated under the name of the Iola Gas Company. This is the only company that has retailed gas in Iola since that date.

In 1894 the Palmer Oil Company of Ohio obtained leases in the vicinity of Iola and began prospecting. The first well was drilled to the southeast of the city, and yielded over 7,000,000 cubic feet of gas daily. Other wells were drilled to the east and northeast, until within a few years the Palmer Oil Company owned a great number of strong gas wells, some of which had a capacity of more than 10,000,000 cubic feet per day. In March, 1899, they sold their entire interests to the Lanyon Zinc Company, a new corporation which bought the smelters and leases from Robert Lanyon's Sons and from W. \& J. Lanyon. Encouraged by the successful wells to the southeast, certain citizens of Iola formed a company known as the City Improvement Company, which had for its objects the bringing of desirable manufacturing enterprises to Iola. In furthering this undertaking they offered free gas to any and all reliable manufacturers for a period of twenty years, provided the gas supply continued. Attracted by this liberal offer, brick plants, smelters, flouring mills, and planing mills were soon built, with the result that Iola, Gas, and Laharpe to-day contain more large factories and industries consuming gas than any other locality in the State.

Prospecting for gas was carried eastward until it was learned that good gas could be found throughout a strip 8 to 10 miles long from east to west, and 4 to 5 miles wide; the north and south limits of the area have not yet been fully outlined.

Mrumboldt.-Guffey and Gailey were the first prospectors to drill wells in the vicinity of Humboldt. In 1894-95 they drilled a number of wells in this territory, not one of which proved very successful. One was in sec. 8 , T. 26 S., R. 18 E., about $1 \frac{1}{2}$ miles southeast of Hum- 
boldt. A few others were drilled to the north of the town. These wells either were dry or produced a small amount of heavy oil; so that they were not considered worth holding and the leases were abandoned later. In 1901 Mr. George Z. Work drilled a well on his land about 100 yards west of the Missouri, Kansas and Texas Railway station at Humboldt. This well produced about 25 barrels per day of a rather heavy oil, having a specific gravity of about $30^{\circ}$ Baumé. Some years earlier, under the direction of the city school board, a well was put down in the corner of the schoolhouse grounds in the southern part of the town. It passed through an oil sand of undetermined capacity and reached a supply of gas, which was used for lighting and heating the school building. A few other wells were drilled, but no important development work was done until the recent development at Chanute, when prospectors again began drilling in the vicinity of Humboldt, and have continued with ever-increasing activity up to the present time. Drilling was first confined to the river valley west and south of town, but later it was extended to the uplands, particularly to the east, and soon reached the entire upland area to the east and southeast of Humboldt, particularly in T. 26 S., R. 18 E., and in the western part of R. 19 E. From here, during the season of 1903, development was carried southward on the uplands to opposite Chanute, making the upland development in the two areas progress along parallel lines.

During the spring and summer of 1895 the Prairie Oil and Gas Company drilled a number of wells west of Humboldt, which produced enough gas to have considerable commercial value. In August, 1897, the gas was piped into the city for general domestic use. The supply was not very large, however, until the rapid drilling for oil began, as above explained. About this time large quantities of gas were obtained, practically in all directions from town, so that at present Humboldt is well supplied.

Chanute.-The history of oil and gas development in the vicinity of Chanute is an interesting and checkered one. In 1894, Guffey and Gailey put down one or two prospecting wells, but, finding nothing, the territory was abandoned and a large acreage of leases given up. Later, the Prairie Oil and Gas Company obtained a strong gas well about 16 miles to the west and laid pipes into Chanute to supply the city with gas. This, in connection with discoveries made elsewhere in the State, stimulated the people of Chanute to continue their investigations. The city took up the matter and drilled a few wells in Neosho Valley to the east of the town. They met with fair success, each well passing through an oil sand at about 730 feet. After passing through 40 feet of shale, the drill reached a gas sand which yielded from 1 to 4 million cubic feet of gas per day. Drilling was continued by the city until a satisfactory supply of gas was obtained for lighting and heating. It is interesting to note that this is the only city in the 


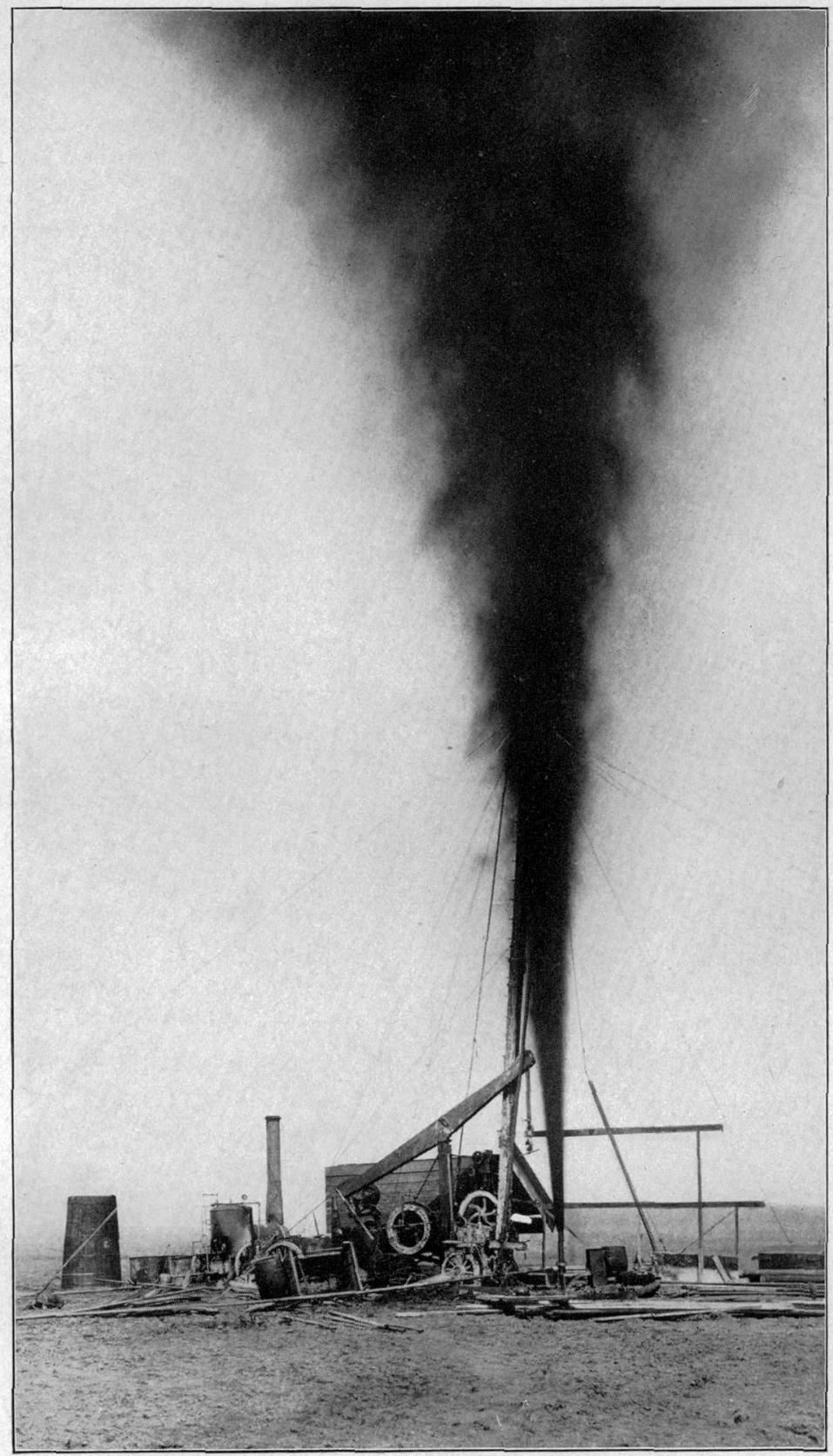

GOLDEN OIL COMPANY'S WELL NO. 2, NEAR CHANUTE, KANS. 
entire oil and gas fields of the State that owns its gas supply. It has made very low rates, as shown later, and yet derives sufficient income to make many municipal improvements.

While investigating the Kansas oil fields in $1899 \mathrm{Mr}$. I. N. Knapp had his attention called to the oil in these city gas wells. Considering the showing sufficiently favorable to warrant him in prospecting for oil, he obtained leases over quite a wide area and began prospecting both east and west of the city of Chanute. It was but a short time until he had a number of fair oil wells in the valley east of the town, and in June, 1900, he began shipping oil to Omaha and Kansas City gas companies, with which he made contracts. This was really the beginning of the oil development in the vicinity of Chanute.

Mr. Knapp was followed by a company composed principally of local business men and citizens of Iola, who organized the Neosho Valley Development Company, obtained leases, and began drilling. . They had fair success from the start and soon had a number of producing wells. They were soon followed by a company composed principally of Kansas City business men, who organized the Southwestern Development Company, which likewise secured leases in the river valley and met with fair success in obtaining oil. From this time on the development was rapid. At the end of a year there were derricks and pipe lines all along the river valley to the east and north of Chanute and halfway to Humboldt. In the midsummer of 1902 the Prairie Oil and Gas Company built a large storage tank at Chanute with a capacity of almost 40,000 barrels. This was followed by a pipe line between Thayer and Chanute which, joined to the Neodesha-Thayer pipe line, gave Chanute a direct pipe line connection with the Standard refinery at Neodesha. A pump was established and the first oil turned into the line about the middle of December, 1902. - The Prairie Oil and Gas Company at this time began extending its lines to oil tanks here and there all through the field. By July, 1903, these had reached as far north as Humboldt and had been carried eastward to the upland developments to the east of Humboldt and northeast of Chanute. During the calendar year 1902 the Chanute territory produced over 165,000 barrels of oil, and could have marketed much more if there had been pipe-line connections. In the first half of 1903 the production was raised from 50,000 to 75,000 barrels per month, with the number of wells constantly increasing.

Development was gradually extended south ward down the river, with only moderate success, in the vicinity of Austin. A few fair oil wells wese obtained in the vicinity of Shaw. Still farther south a few good wells bad been obtained near Urbana and Earlton and in the territory lying to the northeast of Thayer, in the extreme southwest corner of the Iola quadrangle. Gas development likewise extended rapidly

Bull. $238-04-3$ 
in different directions, but particularly to the east and west, making Chanute a great center for gas as well as for oil.

Erie.-Prospecting began in the vicinity of Erie about 1900, but was carried on in a somewhat desultory way until 1902. About this time a company was organized under the name of the Erie Gas and Mineral Company. In August, 1903, it reported that it had drilled 35 wells, 14 of which were gas wells, 7 oil wells, and 14 dry. The gas was piped into the city and supplied practically the entire pópulation. During the summer of 1903 some prospecting was done in the river valley between Shaw and Erie, and, in some cases, gave very satisfactory results, but up to the date above mentioned, nowhere to the southeast of Chanute had oil or gas been found in quantity or volume at all comparable with that in the Chanute and Humboldt fields.

Moran.-The Moran Gas and Crude Oil Company began prospecting in the vicinity of Moran and soon found oil in paying quantities. The territory drilled to the close of the season of 1903 consisted almost entirely of a strip of land about 1 mile wide and 2 miles long lying immediately west of the town. Of the first 19 wells drilled, 12 produced oil, 4 produced gas, and 3 were dry.

Bronson, Elsmore, Savonburg, and Stark.-Prospecting in an irregular manner has been prosecuted to a limited extent in the eastern portion of the Iola quadrangle, particularly at Bronson, Elsmore, Savonburg, and Stark. In a few instances encouraging results were obtained, but thus far not sufficiently so to attract many prospectors away from the other areas.

\section{PRODUCTION.}

Oil. - The rapid rate of oil development in Kansas may be illustrated by the number of wells drilled. There were 725 producing oil wells at the end of June, 1903, not counting a number of unreported wells in some districts, and at the close of the year there were 1,596 producing wells, showing that a larger number of wells were drilled during the last half of 1903 than during all previous time. The subjoined table for the last half of the year covers the entire territory. It will be noticed that Chanute has the largest number, 549, and that Humboldt is second, with 339 . In the territory around these two town: there is a total of 888 , or considerably more than half of all reported. 


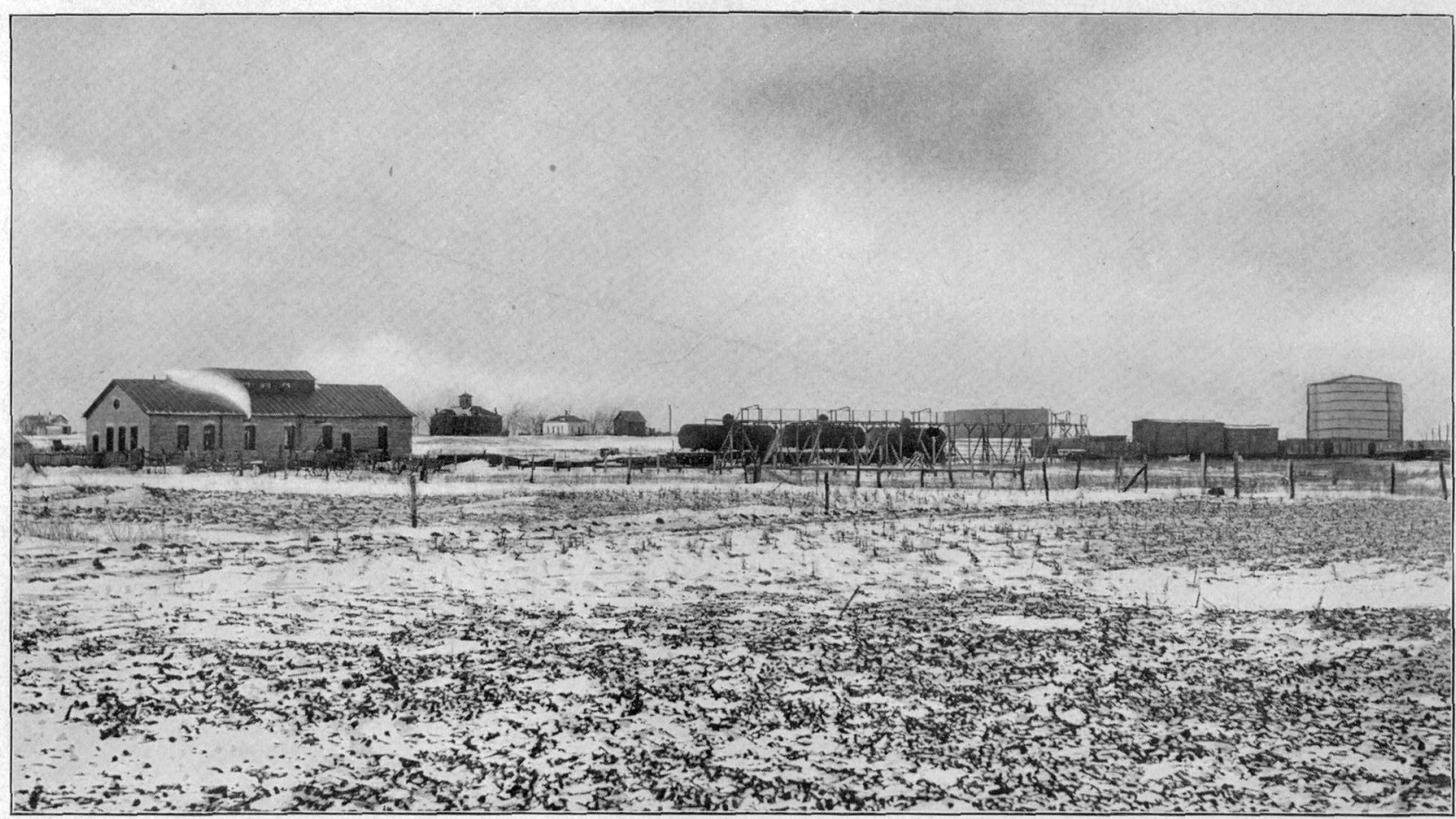

KNAPP PUMPING STATION. STORAGE TANKS, AND LOADING RACKS, CHANUTE, KANS, 
Wells drilled in Kansas, July to December, 1903.

\begin{tabular}{|c|c|c|c|c|c|c|c|c|c|c|c|c|c|c|}
\hline \multirow[b]{2}{*}{ District. } & \multirow{2}{*}{ 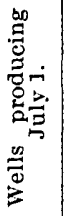 } & \multicolumn{2}{|c|}{ July. } & \multicolumn{2}{|c|}{ August. } & \multicolumn{2}{|c|}{ September. } & \multicolumn{2}{|c|}{ October. } & \multicolumn{2}{|c|}{ November } & \multicolumn{2}{|c|}{ December. } & \multirow{2}{*}{ 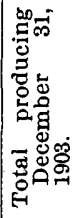 } \\
\hline & & 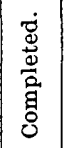 & 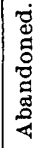 & 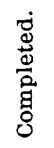 & 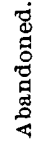 & 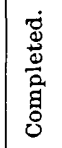 & 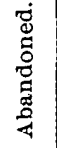 & 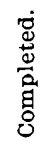 & 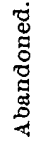 & 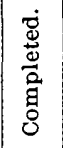 & 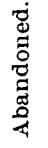 & 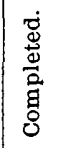 & 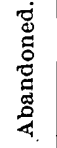 & \\
\hline Shan & 306 & 45 & 0 & 16 & 0 & 25 & 0 & 25 & 1. & 81. & 2 & 56 & 2 & 549 \\
\hline Aumbolc & 133 & 14 & 0 & 35 & 17 & 65 & 21 & 68 & 15 & 44 & 16 & 65 & 16 & 339 \\
\hline $\mathrm{Ne}$ & 161 & 18 & 5 & 35 & 12 & 18 & 5 & 29 & 9 & 39 & 2 & 23 & 10 & 280 \\
\hline Pert & 32 & 9 & 1 & 30 & 10 & 32 & 11 & 25 & 4 & 30 & 1 & 29 & 3 & 157 \\
\hline ndepend & 7 & 10 & 7 & 36 & 18 & 8 & 4 & 32 & 11 & 49 & 10 & 25 & 6 & 111 \\
\hline Cherryvale. & 1.8 & 4 & 1 & 10 & 1 & & & & $\cdots$ & 18 & 1 & 2 & 0 & 49 \\
\hline Bartels & 34 & 7 & 1 & 8 & 1 & 13 & 3 & 5 & 0 & 12 & 2 & 6 & 1. & 77 \\
\hline Che & 33 & & & & & & & & & & & & 5 & 28 \\
\hline Red Fork & 1 & 2 & & & & & & & - & 3 & & & $\cdots$ & \\
\hline Total & 725 & 109. & 15 & 170 & 59 & 161 & 44 & 184 & 40 & 276 & 34 & 206 & 43 & \\
\hline
\end{tabular}

$a$ Indian Territory.

The first oil produced in the Iola quadrangle was marketed in 1900, the oil being shipped in tank cars by Mr. Knapp. He continued shipments by rail throughout 1900,1901 , and 1902 , and well into 1903 , since which time his production is included in the pipe-line runs given in the monthly reports by the Prairie Oil and Gas Company. Figures for the total production of oil during 1900 or 1901, are not obtainable. It is probable, however, that the two years' combined production would be about 80,000 barrels. During 1902 the production was much greater, and rapidly increased throughout 1903 . In 1902 the total production at Chanute was 165,336 barrels, about two-thirds of it being produced by Mr. Knapp. By the close of 1903, however, a number of other companies were regular producers. The subjoined table, showing the monthly production of Chanute and Humboldt, includes only pipe-line runs, to which should be added the oil shipped by rail and a small amount delivered to the wagon trade at Humboldt and sold to brick plants and other manufacturers.

Humboldt produced no oil in 1902, except from one well belonging to Mr. G. Z. Work. It is estimated that he sold at least 500 barrels to the wagon trade. In 1903 this same kind of trade was continued; by June shipments by rail began; and in the late summer the pipe lines were extended to the Humboldt field and the delivery of oil increased very rapidly, as shown by the table. At the close of 1903 probably fully one-third of all the wells in the Chanute-Humboldt district were still standing idle because pipe lines had not yet reached them. The 
pipe-line runs, therefore, are only an indication of what the total production would have been had market facilities been at hand.

Shipping oil by rail was begun at Moran late in 1903, but on account of poor shipping facilities only a small amount was marketed.

Other centers of smaller production, such as Erie, Shaw, Urbana, etc., either marketed no oil or had their production included with the pipe-line runs from Chanute. Nothing was marketed from any of these points until late in the year, and since then but little, because developments were scarcely beyond the prospecting stage.

Oil production of Iola quadrangle in 1903.

[Barrels.]

\begin{tabular}{|c|c|c|c|c|c|}
\hline . & Chanute. & Humboldt. & & Chanute. & Humboldt. \\
\hline January - & $25,811.40$ & & July ............ & $34,481.65$ & 578.00 \\
\hline February & $26,291.60$ & & August & $67,822.28$ & - \\
\hline March ... & $12,812.41$ & & September.. & $82,850.23$ & $1,743.50$ \\
\hline April.... & $9,965.90$ & ........ & October.......... & $75,141.57$ & $6,079.70$ \\
\hline May... & $46,033.57$ & $431: 00$ & November ..... & $74,175.44$ & $6,743.22$ \\
\hline June ... & $34,494.05$ & 144.43 & December...... & $74,182.64$ & $6,868.22$ \\
\hline
\end{tabular}

By way of comparison, figures for the production of the entire State and adjoining points in the Indian Territory may be of interest.

Oil production of Kansas and adjoining Indian Territory in 1903.

[Barrels.]

\begin{tabular}{|c|c|c|c|c|c|c|c|c|}
\hline & Chanute. & $\begin{array}{l}\text { Hum- } \\
\text { boldt. }\end{array}$ & Neodesha. & Peru. & $\begin{array}{c}\text { Independ- } \\
\text { ence. }\end{array}$ & $\begin{array}{l}\text { Cherry- } \\
\text { vale. }\end{array}$ & $\begin{array}{l}\text { Indian } \\
\text { Territory } \\
\text { and Okla- } \\
\text { homa. }\end{array}$ & Total. \\
\hline January .... & $25,811.40$ & $\cdots$ & $7,440.38$ & $2,975.06$ & $\ldots \ldots \ldots \ldots$ & $1,154.87$ & $7,146.76$. & $44,528.47$ \\
\hline February .. & $26,291.60$ & & $6,328.29$ & $2,845.79$ & & 965.15 & $5,697.34$ & $42,128.17$ \\
\hline March ..... & $12,812,41$ & & $7,586.06$ & $3,773.14$ & & $1,205.76$ & $4,126.93$ & $29,504.30$ \\
\hline April....... & $9,965.90$ & $\ldots \ldots \ldots$ & $6,706.38$ & $3,036.34$ & & 425.56 & $7,033.88$ & $2 \pi, 168.06$ \\
\hline May........ & $46,033.57$ & 431.00 & $9,305.74$ & $2,634.15$ & & $1,083.23$ & $4,277.78$ & $63,765.47$ \\
\hline June ....... & $34,494.05$ & 144.43 & $6,836.69$ & $2,133.98$ & & 922.94 & $8,239.81$ & $52,771.90$ \\
\hline July........ & $34,481.65$ & 578.00 & $6,390.50$ & $2,133.64$ & & 735.21 & $16,102.74$ & $60,421.74$ \\
\hline August.... & $67,822.28$ & $\ldots \ldots \ldots$ & $10,838.35$ & $3,272.90$ & & $1,353.24$ & $10,490.69$ & $93,777.46$ \\
\hline September. & $82,850.23$ & $1,743.50$ & $9,900.52$ & $4,930.83$ & $5,759.94$ & 705.29 & $8,821.85$ & $114,712.16$ \\
\hline October.... & $75,141.57$ & $6,079.70$ & $12,528.69$ & $2,952.19$ & $15,297.01$ & $1,683.06$ & $14,315.49$ & $127,997.71$ \\
\hline November. & $74,175.44$ & $6,743.22$ & $19,821.00$ & $11,987.89$ & $34,776.54$ & $3,634.35$ & $24,613.01$ & $175,751.45$ \\
\hline December.. & $74,182.64$ & $6,868.22$ & $28,986.48$ & $21,898.78$ & $50,876.54$ & $10,843.76$ & $34,831.69$ & $238,488.11$ \\
\hline
\end{tabular}

Kansas oil wells are not very strong if compared with the more noted "gushers" of America. The wells in Neosho Valley, at Chanute or at Humboldt, had an average initial production of about 20 barrels, the strongest varying from 100 to 300 barrels daily capacity and the weakest from 1 to 3 barrels. 
On the uplands to the east of the river, southeast of Humboldt and northeast of Chanute, the general character of the wells was much the same, except that a few were found which were stronger than any in the river valley. In the autumn of 1903 Martin Brothers brought in a well on the Lockhart land, sec. 13, T. 26 S., R. 18 E., which began flowing at about 1,000 barrels per day. A few weeks later the Minneapolis Oil and Gas Company brought in a well near by, likewise on the Lockhart land, which filled a 250 -barrel tank in 250 minutes, a rate of about 1,440 barrels a day. These two had the greatest initial capacity of any thus far found in the State. Their rate of flow declined rapidly but remained at about 200 to 300 barrels per day for some months. In December, 1903, a few strong wells were brought in west of Chanute, just across the west boundary of the Iola quadrangle. They were much stronger than the average wells in Neosho Valley, but not equal to the wells on the Lockhart land.

Elsewhere in Kansas, outside of the Iola quadrangle, the oil wells are similar to those described. Southwest of Independence, in Montgomery County, near Bolton, during the summer and early autumn of 1903, a remarkable oil field was developed. The first good well was brought in on the Banks land, sec. 8, T. 33 N., R. 15 E. It was but a short time until a large number of wells were completed, averaging from 100 to 300 barrels per day, a great proportion of which were flowing wells. At present it seems that this is destined to be the greatest individual oil pool in the State. In the vicinity of Cherryvale good oil wells are becoming common, indicating that this also may soon be an oil center. Coffeyville also, late in 1903, became the center of active drilling operations.

Gas.-It is impossible to estimate with a high degree of accuracy the amount of gas produced in the Kansas fields. The historical sketch already given shows that gas was used in Iola as early as 1873 , but pipes were not laid down for its general use until twenty years later, 1893. From that time to the present it has been used almost to the exclusion of other fuels for heating and lighting and for generating steam and producing furnace heat in the numerous manufacturing enterprises.

At Iola the manufacturing cońcerns are zinc smelters, brickkilns, Portland-cement factories, flouring mills, planing mills, and a number of small factories, such as are usually found in thriving young cities, including laundries, creameries, bakeries, etc. The zine smelters of the entire Kansas gas field have produced 375,000 tons of spelter from gas furnaces, of which more than 300,000 tons were produced at Iola, Laharpe, and Gas. The gas used is the equivalent of about $2,000,000$ tons of good soft coal. Kansas gas has burned about $650,000,000$ brick, which would have required about 250,000 tons of coal. Of these brick about one-third were burned within the Iola quadrangle. The 
Portland-cement factory at Iola during its operation has produced, in round numbers, $2,000,000$ barrels of cement, consuming gas equivalent to 200,000 tons of coal.

The consumption of gas in the lesser factories and for domestic use has been great, aggregating more than that used in the factories. The rates charged are very low. Some data have been gathered on domestic consumption, but principally in terms of the value of gas rather than its quantity. It is probable that the entire Kansas field bas produced gas having a value of very nearly $\$ 5,000,000$. The rates charged by gas companies in different cities vary widely, but with few exceptions the modes of estimating values are the same. A charge of so much per month is made for each light and for each of the different kinds of stoves used. The most common price is $25^{\circ}$ cents for a light and from $\$ 1.50$ to $\$ 2.50$ per month for a stove. A cooking stove for a residence is charged more than a warming stove, because it is usually larger and consumes more gas. Stoves in business houses, hotels', etc., are generally larger in size than those in residences, and consequently are charged a higher rate. At Chanute the gas is owned and sold by the city and prices are fixed by city ordinance. By the terms of the city ordinance which becomes effective February 2, 1903, gas charges were reduced one-half. Accordingly, the rates now charged are: Gas jet, 10 cents per month; heating stove, $\$ 1.50$ per month; cooking, $\$ 1$ to $\$ 1.50$ per month. For all manufacturing purposes the gas is sold by the thousand cubic feet. A concern using 1,000 or less cubic feet per month is charged 20 cents; $2,000,35$ cents; $3,000,50$ cents; 8,000 , $\$ 1 ; 10,000, \$ 1.25$; above 10,000 the rate is 5 cents for each additional thousand. At Erie all consumers use meter rates at 25 cents per thousand cubic feet burned.

The mode of burning gas is very objectionable from the standpoint of economy. All lights are allowed to burn continuously day and night excepting in extreme hot weather, when some of the lines are turned off in order to prevent throwing too much heat into the rooms.

If good meter rates had been established throughout the entire gas region it is probable that consumers might have used all the gas they needed for their comfort in lighting and heating without consuming more than from one-third to one-half of what has actually been burned.

Gas-producing territory. - The strength of gas wells varies from wells in which so little gas is found that they have no commercial value up to those which have a capacity of more than $10,000,000$ cubic feet. The best wells developed thus far are in the Iola-Laharpe region. This territory extends about 9 miles east and west and 4 miles north and south, and has supplied much more gas than any other field in the State. Other fields are known which may prove to be as good, but they have not been drawn from so extensively. The original static pressure in the Iola area was about 325 pounds per 
square inch and the best wells generally had a flowing capacity of from $5,000,000$ to 10,000,000 cubic feet per day. East of Laharpe and west of Moran is a territory not yet prospected. Moran is moderately supplied with gas, but the wells are weak compared with those at Laharpe and Iola.

Very little prospecting has been done in the extreme north end of the Iola quadrangle. A few wells to the north of Carlyle have proved of little value, and likewise to the northwest of lola. Small gas wells have been found in the western part of Bourbon County, near Bronson. About 3 miles southwest of Iola, on the Culbertion land, there are two gas wells, one of which had an initial capacity of about $3,000,000$ cubic feet per day. There is a large area betweer Iola and Humboldt hardly touched with the drill. What little pros pecting has been done' bas not yet yielded very encouraging results although too few wells have been drilled to permit one to form a judg. ment on the territory.

Gas has been found in comparative abundance in the vicinity of Humboldt. West of Humboldt, just beyond the limits of this quadrangle, are a number of gas wells which have a capacity of from $1,000,000$ to $5,000,000$ cubic feet per twenty-four hours. East and southeast of Humboldt a number of otber wells of similar capacity have been found, but no gas territory distinct from the oil territory has yet been developed. This field joins the gas territory in the vicinity of Chanute, with no sharp boundary line between them.

In the vicinity of Chanute gas is abundant. The first gas wells were found in Neosho River Valley, east of the town, and on the low hills in the southeastern part of the town. In fact, so many wells were found in this latter place that the name Gas Ridge was applied to it some years ago. The territory here seems to be spotted, an occasional dry hole being sometimes found with producers on either side of it. The upland lying west of the town was abandoned at one time, as the few wells drilled proved to be failures. But later other wells were drilled a little farther west and also a mile or two to the south, which proved to be good producers. During 1902 and 1903 a number of good wells were drilled in the hills on the east side of the river from $2 \frac{1}{2}$ to $3 \frac{1}{2}$ miles east of Chanute. One particularly, which was completed in July, 1903 , is almost as good a well as any in the State.

The territory lying to the south of Chanute in the southeast corner of the Iola quadrangle produced but little up to the close of 1903 . A few light wells have been found, particularly near. Urbana and south of the quadrangle toward Thayer and Galesburg, but the prospecting is not extensive enough to show the character of this part of the field.

In the vicinity of Erie small gas wells, with a daily flowage capacity of from 100,000 to 500,000 cubic feet, are found in comparative abundance. The first 35 holes drilled by the Erie Gas and Mineral Company 
obtained 14 gas wells, 7 oilers, and 14 failures. The gas is used satisfactorily to light and heat the town.

Outside of the places mentioned but little gas has yet been found. Considerable prospecting has been done at St. Paul, but with negative results. The first well at Walnut was drilled during the autumn of 1903 , and was practically a failure, showing only a very small amount of gas. Other wells are to be drilled there, but what success they will have can not be foretold. Stark, Savonburg, Elsmore, and Bayard are similarly situated. A few wells have been drilled which produce small amounts of gas, but none sufficient to be of any considerable commercial importance. Possibly future prospecting will find larger quantities of gas.

\section{UTILIZATION OF GAS IN ZINC SMELTING.}

Attracted by the cheap fuel supplied from the numerous and strong gas wells, zinc-smelting companies years ago began erecting large smelters in the Kansas gas fields. To-day more than one-half of all the spelter produced in the United States is smelted by Kansas gas, and considerably more than half of this is produced by smelters located within the Iola quadrangle.

Development of the industry. - The first smelter erected was located at Iola and built by the Robert Lanyon's Sons Company. The company began producing spelter in December, 1896, but the plant was not brought into successful operation until the spring of 1897. A large stone building erected originally for a carriage manufactory was used for furnace rooms (Pl. VIII, $B$ ).

As this was the first plant to use natural gas for fuel, it was largely in the nature of an experiment, and its success was watched with great interest. It was recognized from the start that the difficulty in the use of gas, should any arise, would be in the proper distribution of heat through the furnaces. It was soon found that this could be accomplished readily by providing intakes of gas, arranged in different places, as experience showed desirable. The gas was mixed with the proper amount of air by specially contrived mixers, built on the general principles of the Bunsen-burner mixer, or those so widely employed in domestic consumption of gas. The success of the company led to the enlargement of the plant from time to time, until now it has 3,200 retorts. After about a year's trial the company built another large smelter at Laharpe, which has been enlarged from time to time until it has a capacity at present of 3,440 retorts.

The success achieved by the Robert Lanyon's Sons Company soon attracted the attention of others. During the summer of 1897 , W. \& J. Lanyon, who were operating zinc smelters in the coal fields at Pittsburg, Kans., erected a trial smelter of 1,800 retorts at Iola, and began the production of spelter late in December of the same year. Their 


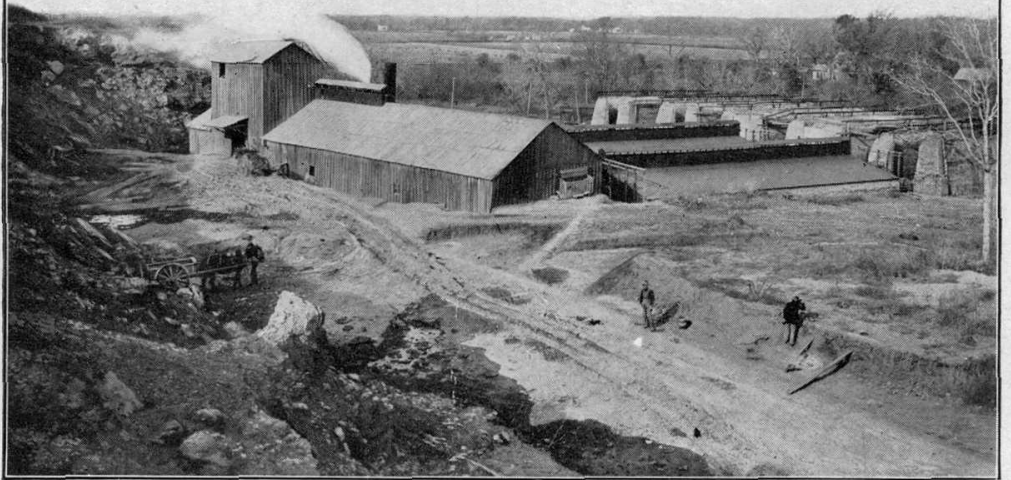

A. IOLA BRICK COMPANY'S PLANT NO. 1

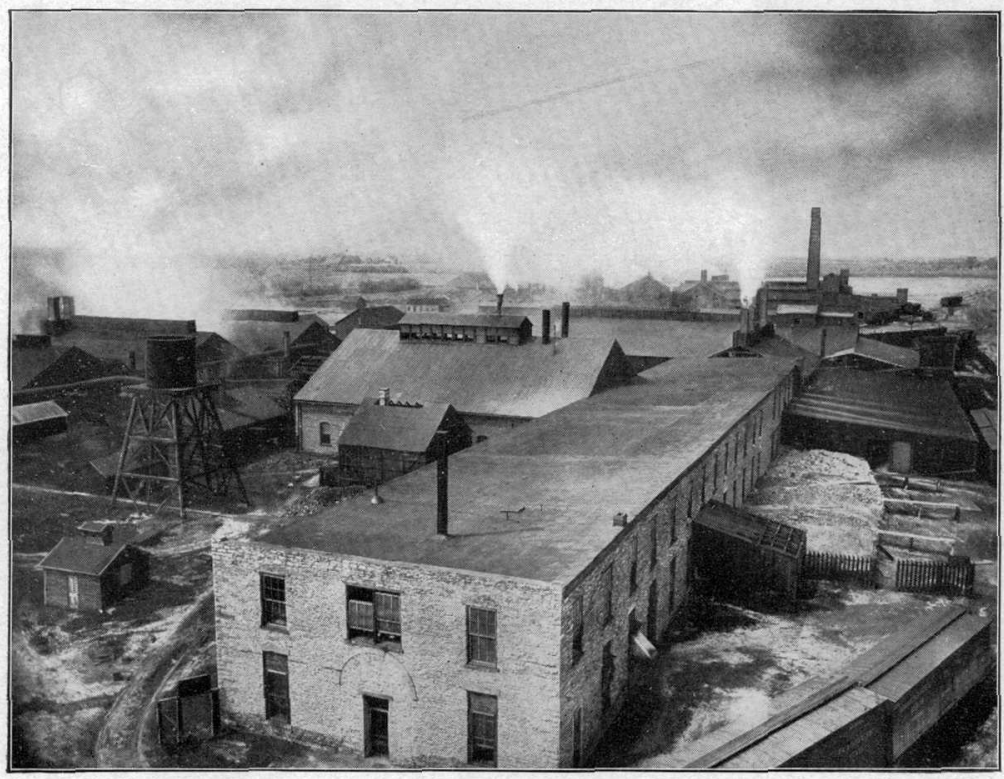

B. LANYON ZINC COMPANY'S SMELTER NO. 1 
plant was a success from the first and was gradually enlarged until at the present time it has 3,200 retorts.

These different plants were operated separately until March, 1899. Previous to this time the Palmer Oil Company of Ohio had obtained leases on a large acreage in the vicinity of Iola and Labarpe, and had obtained a number of strong gas wells, ranging in capacity from $5,000,000$ to 10,000,000 cubic feet per day. A new company was formed which bought the gas property of the Palmer Oil Company and the zinc smelters of both the firms above named, receiving the property in March, 1899, since which time all of these smelters have been operated by one management, under the firm name of the Lanyon Zinc Company. Late in 1903 they had a total of 9,840 retorts in commission.

In 1902 the Lanyon Zinc Company erected rolling mills at Laharpe, which began operations on May 3, of that year. These mills were successful in their operation and were enlarged during the summer of 1903. At the present time they have a daily capacity of from 40,000 to 50,000 pounds of finished sheet zinc.

In 1899 the Prime Western Spelter Company erected a plant of 1,240 retorts and built a little town named Gas, situated 2 or 3 miles east of Iola. The plant was owned and controlled by Mr. L. T. McRea, Mr. J. A. Daly, and Dr. L. H. Callaway. About the same time the Cherokee-Lanyon Spelter Company, of Pittsburg, erected a plant at the same place, with a capacity of 1,240 retorts. These two plants were operated successfully from the start, but later were sold. Also, in 1898, Mr. George E. Nicholson, a zinc smelter from Nevada, Mo., built a plant of 1,200 retorts capacity about 1 mile east of Iola, which was operated successfully until bought out late in 1902, having been previously enlarged to a capacity of 1,640 retorts.

In 1902 the United Zinc and Chemical Company built a zinc smelter at Iola and a sulphuric-acid factory in connection with it. The plant was completed and began operations in March, 1903. The roasting furnace is so arranged that fumés from the burning gas do not come in contact with the ore, the heat entering the roasting chamber proper by being transmitted through a fire-clay floor on which the ore rests. Air is slowly drawn over the heated sulphide ore and oxidizes it, producing a sulphur dioxide $\left(\mathrm{SO}_{2}\right)$. By regulating the draft properly and by excluding the products of combustion from the gas, a greater concentration of sulphur-dioxide vapor can be obtained than from the ordinary calcining furnace. It can thus be passed directly into the leaden acid-generating chamber.

Late in 1902 a new company was organized as the New Jersey Zinc Company. It bought the plants of George E. Nicholson and the Prime Western Spelter Company, and has since operated them as one plant. During the last summer (1903) it has been enlarging its plant to almost double its original capacity. Also, in 1903, a Mr. Braun 
began building a small smelter at Laharpe, which is expected to go into commission near the end of the year.

On account of small values of gold and silver being found in zinc ores shipped from Colorado to Kansas furnaces, it was thought desirable to put up a trial furnace for the purpose of extracting such from the residue obtained from the retorts. In 1902 the Cherokee-Lanyon Company put up such a trial smelter. They shipped ores from Colorado and from Canada known to have suall gold and silver values and extracted the precious metals from the retort residues. After a trial of about a year they abandoned the enterprise and permanently closed down their gold and silver smelter, finding that the expense was greater than the profit.

At the present time, summarizing the above data, there are in operation in the Iola quadrangle zinc smelters belonging to four different companies, with an aggregate capacity of about.17,000 retorts, not including the ones at Laharpe, which are not yet completed.

Method of smelting.-Zine smelting with gas for fuel is conducted very similarly to zinc smelting with coal. Kansas smelters use almost exclusively ore from the Joplin-Galena mining district, which supplies zinc blende or zinc sulphide. Such ores, after being properly pulverized, are passed through the roasting or calcining furnace. Here the gas flame, mixed with an excess of air, comes in direct contact with the ore. The sulphur is gradually expelled as sulphur dioxide $\left(\mathrm{SO}_{2}\right)$, leaving the zinc in the form of zinc oxide $(\mathrm{ZnO})$. From the calcining furnace the zinc oxide is taken to the retort or sublimation furnace, mixed with the proper amount of carbon, and placed in externally heated fire-clay retorts. These retorts, which are circular in cross section, 4 feet long and about 10 inches internal diameter, are arranged in the furnace so that they form a series of rows one upon the other, each retort being almost horizontal. The back or inner edge is closed in the making, but the outer end, which projects slightly through the wall of the furnace, is left open. After the charge is put into the retort a conical, hollow, fire-clay condenser is put into the open end of the retort. This gathers the vapor of metallic zinc volatilized by the heat of the furnace and holds it until enough has condensed to be drawn off. As this condenser is entirely outside the furnace its temperature is below the point of volatilization and above that of solidification and consequently serves the purpose well. The bulk of the carbon, which is mixed with the zinc oxide before it is put into the retorts, is in the form of coke made principally from slack coal obtained from the coal mines in Cherokee and Crawford counties. With this coke a small or varying amount of pulverized anthracite is used, to which is added a small proportion of pulverized bituminous coal, the whole charge being thoroughly mixed together. The retort is completely filled, after which an iron rod about 1 inch in diameter is 


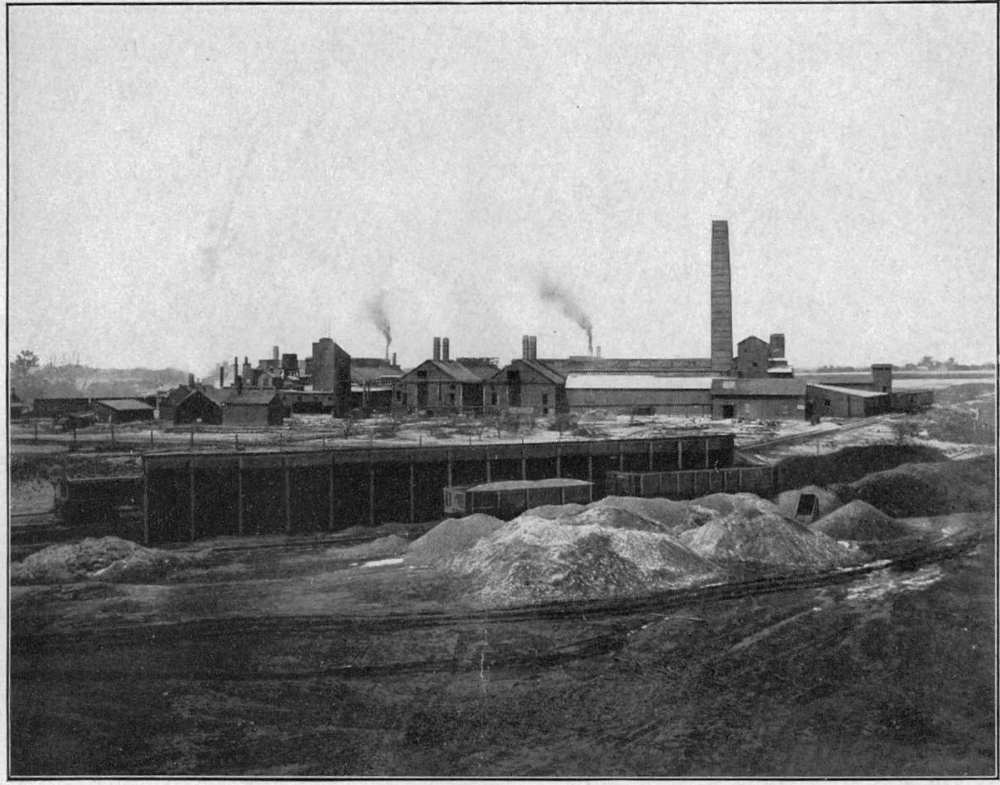

A. LANYON ZINC COMPANY'S SMELTER NO. 2.

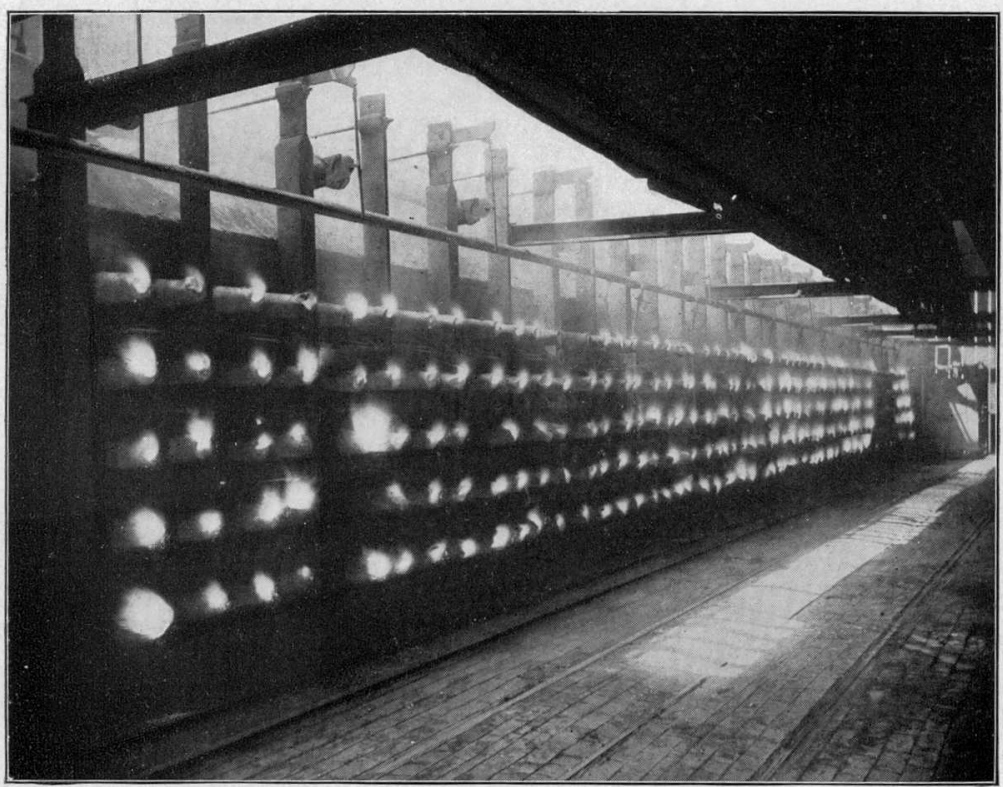

B. BANK OF RETORTS SHOWING FLAMES AND ZINC FUMES ESCAPING FROM THE ENDS OF CONDENSERS. 
forced into the top part of the charge through the entire length of the retort to make a little opening, along which the first volatile material may pass. when the smelting has begun. The conical condenser is then inserted and the heat of the furnace soon causes chemical action to begin. The bituminous coal is added in order to produce a little volatilization early in the process. As the gas thus formed passes out of the retort it sets up to some extent an outward curgrent. When the hot carbon reduces zinc oxide to metallic zinc the latter is immediately volatilized and driven over into the condenser. The carbon unites with the oxygen of zinc, producing a small amount of carbon dioxide $\left(\mathrm{CO}_{2}\right)$, but principally carbon monoxide $(\mathrm{CO})$, a combustible gas that is set on fire at the outer end of the condenser. The small flame thus produced is colored slightly by traces of zinc vapor and other materials which may be in the ore, particularly cadmium, should any be present. The operator judges the temperature of the furnace and the rate of progress largely by the color of the flame, which varies from time to time with varying conditions of temperature and progress of reduction.

Production of spelter in 190\%. - A retort, such as has been described above, produces from 23 to 25 pounds of metallic zinc for each charge, the amount varying slightly with the grade of the ore, but rarely exceeding these limits. It takes twenty-four hours to dispose of one charge, so the capacity of a furnace is obtained by allowing about 24 pounds of spelter per day for each retort. There are 17,000 retorts in the smelters in the Iola quadrangle at the present time. If no allowances were made for shut downs for repairs and other necessary stoppages, they would be able to produce nearly 75,000 tons of spelter per annum, an amount almost as great as the total State production for 1902. The difference between the figures obtained in this way and the actual amount of production is due to a number of causes, the principal one being that no furnace can be operated continuously year after year without repairs. It is quite unusual to find a large smelting plant with all of its furnaces in commission. Almost always one or more of them will be closed for repairs, or for some other temporary cause.

In 1902 the furnaces above described produced about 66,000 tons of spelter which, at the New York quotations, had a value of $\$ 6,201,600$.

\section{PHENOMENA OF GAS WELLS.}

By George I. ADAMs.

When, in the operation of drilling, a reservoir of gas is encountered, its presence is immediately known by the fact that it flows from the well. As the drill goes deeper the volume of gas increases until it reaches the maximum production. In many instances the force of the gas assists in opening the reservoir by blowing out fragments of rock, and the well is said to "drill itself in." If the gas is under high pressure the force may be great enough to lift the drilling tools out of 
the well. The task of confining the gas is by no means an easy one. Sometimes the pressure causes the casing to rise out of the ground and it is necessary to secure it by means of anchors. If there are defects in the casing or valves they may break as a result of the pressure when an attempt is made to close the well. The sound made by the issuing gas is often deafening, and if the gas is ignited the flame causes a roar which may be heard for miles. To those who are at work around the well the effect is sometimes nauseating and otherwise disagreeable, and it is necessary to protect one's ears or permanent deafness may result.

The phenomena connected with the occurrence of natural gas, although now fairly well understood, are in a way mysterious and elusive. The first exploitation of gas began in the early seventies in Pennsylvania. Although but a short time has elapsed since then, the laws governing the utilization of gas are well understood by many operators. For the information of those who are interested in the occurrence of gas or who may wish to engage in prospecting, it is proposed here to review certain of the phenomena of gas wells.

For a proper understanding of the laws which govern the flow and pressure of gas it may be well first to explain the nature of a gaseous body. In a gas the molecules are separated beyond the limits of cohesive attraction so that they are free of all restriction upon one another. It is not known. if there is a limit to the rarefaction of gases when they are unconfined; that is, at what distance the attraction of the molecules for each other would just balance the mutual repulsion. Gas may be said to fill a reservoir no matter how small the amount may be.

Natural gas, as it is commonly called, is a mixture of several gases, of which marsh gas $\left(\mathrm{CH}_{4}\right)$ is found in the Kansas product to constitute from 92 to 98 per cent. The following table ${ }^{a}$ shows the composition of gas found at various localities in the Kansas field:

Composition of natural gas found in the Kansas field.

\begin{tabular}{|c|c|c|c|c|c|c|c|}
\hline & Paola. & $\begin{array}{l}\text { Osawato- } \\
\text { mie. }\end{array}$ & Iola. & $\begin{array}{l}\text { Cherry- } \\
\text { vale. }\end{array}$ & $\begin{array}{l}\text { Coffey- } \\
\text { ville. }\end{array}$ & $\begin{array}{c}\text { Independ- } \\
\text { ence. }\end{array}$ & Neodosha. \\
\hline Carbon dioxide... & 0.33 & 0.22 & 0.90 & 0.22 & 0.00 & 0.44 & 1. 00 \\
\hline Olefiant gas, etc..... & .11 & .22 & .00 & .00 & .35 & .67 & .22 \\
\hline Oxygen............... & .45 & $\operatorname{Tr}$ & .45 & .22 & .12 & Tr. & .65 \\
\hline Carbon monoxide ... & .57 & 1.33 & 1.23 & 1.16 & .91 & 33. & .50 \\
\hline Marsh gas........... & 95.20 & 97.63 & 89.56 & 92.46 & 96.41 & 95.28 & 90.56 \\
\hline Nitrogen..... & 2.34 & .60 & 7.76 & 5.94 & 2.21 & 2.28 & 7.07 \\
\hline Hydrogen . . . . . . . . & .00 & .00 & .00 & .00 & .00 & .00 & .00 \\
\hline Total ... & 100.00 & 100.00 & 100.00 & 100.00 & 100.00 & 100.00 & 100.00 \\
\hline
\end{tabular}

$a$ Bailey, E. H. S., Kansas Univ. Quart., vol. 4, No. 1, July, 1895, p. 10. 
Gas diffuses readily and when it issues from the well immediately becomes mixed with air. When it is used as fuel the necessary oxygen from the air is added to it by means of a mixer, which allows the diffusion of the air and gas to take place before it is burned. Gas is absorbed by water and oil, the amount absorbed depending upon the pressure and temperature. As an aid to the understanding of the relations of gas absorbed in a liquid ordinary carbonated water may be cited. When gases are once formed they are very stable and retain their condition. excepting under very high pressure and low temperature. The degree of compression or density of gas is dependent upon the heat and pressure to which it is subjected. Gas expands against any constant pressure by one four hundred and ninetyfirst part of its volume for every degree Fahrenheit

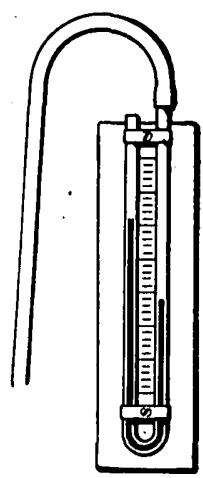

Fic: 5.-U-shaped gage with flexible hose for attachment in mensuring gas pressures.

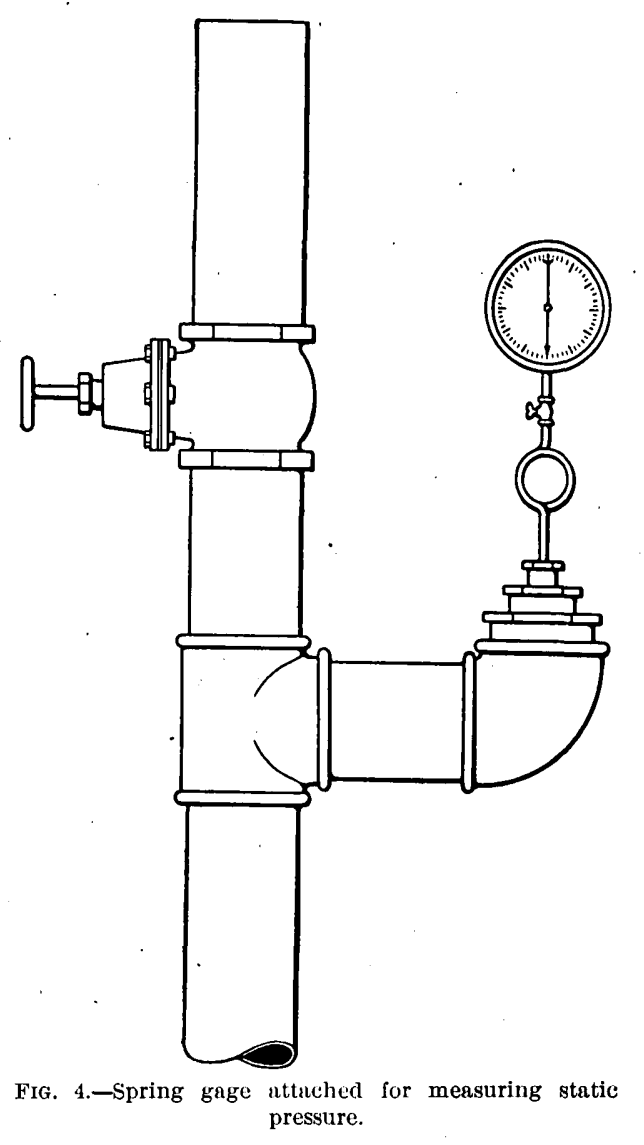
es or increases at exactly the same rate that the pressure increases or decreases. The expansive force of gas is exerted in all directions and the pressure on confined bodies is transmitted undiminished.

Static or closed pressure.-A body of gas confined within the earth, if not subjected to geologic changes, remains in a quiescent state until reached by the drill. A well forms an artificial extension of the body of gas and affords an opportunity to measure its degree of condensation. When the pressure in a closed well is moderately high it may be measured by connecting a spring gage with the casing (fig. 4). The gage records the pressure in the same way as does a steam gage on a boiler. If the pressure is small a $U$-shaped tube (fig. 5), contain- 
ing mercury, water, or other liquid, may be connected with the casing and the pressure registered by the height to which the column of liquid rises. The U-shaped gage, because of the nature of the instrument, can be used only for low pressures.

While a measurement so taken is commonly stated to be the pressure of the gas in the well, the fact should not be lost sight of that it is the measure of the pressure exerted by the gas on all parts of the reservoir of which the well is an artificial prolongation. The static pressure recorded when a well is first brought in is commonly spoken of as its initial pressure. Any variations which are recorded in subsequent measurements are found to be lower. For example, if, after a well is measured, it is allowed to blow off and is then suddenly closed the pressure on the gage will be lower than it was before the valve was opened, the reduction being caused by the friction encountered in flowing. However, the index on the dial of the gage will gradually change its position, indicating a higher pressure and in the course of a short period will record the same pressure as was just previously note'.

(A)

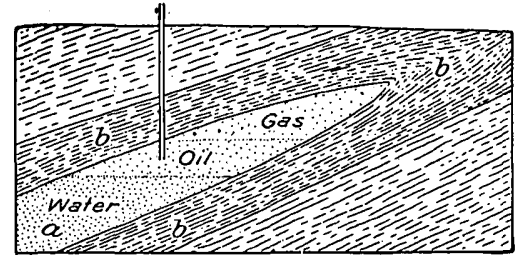

(B)

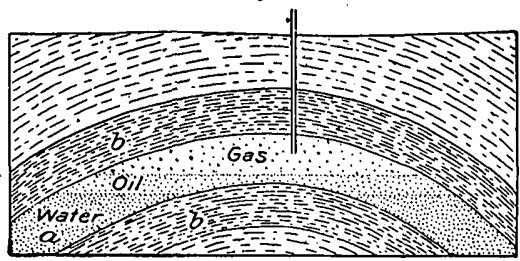

Fig. 6.-Types of oil and gas reservoirs.

$A$, inclined bed of sandstone $(a)$ sealed in by shales $(b)$, but somewhere in communication with water under hydrostatic pressure.

$B$, sandstone bed $(a)$ interstratified with impervious beds $(b)$ and forming an arch or anticline, and somewhere in connection with water under hydrostatic pressure.

In the Kansas field a pressure of 325 pounds to the square inch is not unusual. Many wells show a lower pressure, and some are reported to reach 600 pounds. The force of the gas issuing from a well as computed in horsepower reaches a surprising figure, being so great that the gas may be turned directly into the cylinder of a steam engine and its expansion utilized as a source of power. High pressures in the field are desirable since they enable the gas to be conveyed long distances through ramifying pipe lines, where the friction which must be overcome is a serious element.

After a well has produced for a considerable period of time the pressure will be found to have fallen off. This is the history of the wells in all fields. The fact may be taken as an indication that the exhausting of the gas changes the relations in the reservoir. The gas confined within the earth occupies the interstitial spaces in sandstones and porous rocks. A gas reservoir accordingly is a complex series of openings. Its limits are the impervious rocks which inclose 
its upper surface and the water or oil which lies below it. The two types of reservoir considered from the standpoint of the structure of the rocks are shown in the accompanying figure (fig. 6).

The degree of density of gas under hydrostatic conditions in a reservoir depends upon the pressure exerted upon it by the oil and the water. The amount of this pressure is due to the hydrostatic head. If the place of intake of the water is known and it is assumed that the water-bearing stratum is completely saturated, the pressure of the gas can be computed by measuring the height of the column of water acting on it. The observed pressure in closed wells is found to check closely with the results obtained where these factors are known. A simple example illustrating the hydrostatic head is shown in the accompanying diagram of an artesian well (fig. 7).

The fact that a well shows a high pressure is evidence of the relative density of the body of gas, but it does not indicate the capacity of the reservoir. If the hydrostatic conditions are perfect the pressure of the gas will be very nearly maintained throughout the life of the well whether the reservoir is large or small, the difference in pressure being due simply to change in the level of the water.

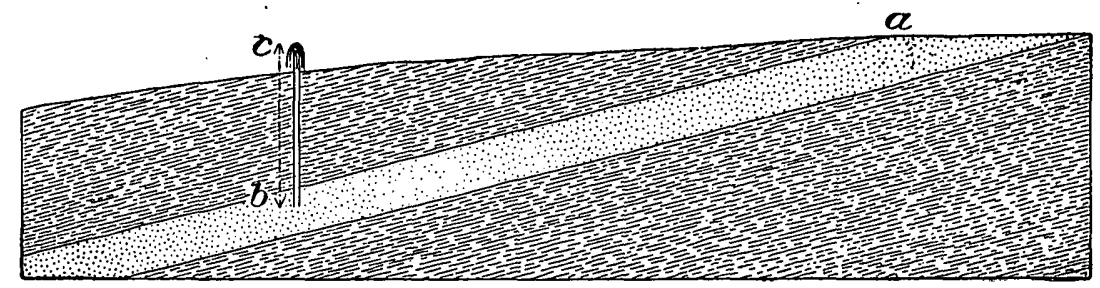

IIG. 7.-Diagram of an artesian well: $a$, point of intake; $b$-c, height of colum n of water exerting hydrostatic pressure at $b$.

As the gas in the reservoir is reduced in quantity by flowing out of the well the water or oil limiting its lower surface rises. The amount of decrease in pressure may be measured by subtracting the weight of a column of water or oil having a height equal to the difference in its original and subsequent levels. Inasmuch as the movement of water in the earth's crust is much retarded by friction, and in some cases may be modified by changes in porosity of the strata owing to cementation of the rocks after the gas has accumulated, the observations on wells show variations from ideal conditions.

Dynamic or open-flow pressure.-In flowing through a well casing gas encounters the resistance of friction, which is relatively large in small pipes. The dynamic or open-flow pressure at the mouth of the well is equal to the static or closed pressure minus the friction. As will appear later in this discussion, the velocity of the flow bears a fixed relation to this pressure.

In all measurements under ordinary conditions atmospheric pressure is a factor. It may, however, be neglected, since the apparatus used 
is so constructed that atmospheric pressure on the gas is balanced by atmospheric pressure on the opposite side of the diaphragm in spring gages or of the column of liquid in U-shaped tube gages. The measurements recorded are accordingly for gas under pressure of one atmosphere. The weight of a column of air at sea level.is about 14.7 pounds per square inch. Corrections for altitude may be made by reference to barometric readings, but in ordinary work are usually neglected. In accurate measurements of volume corrections for temperature are made. The volume of flowing gas is computed at $40^{\circ} \mathrm{F}$., and for gas in a reservoir a temperature of $50^{\circ} \mathrm{F}$. is taken as the standard. The specific gravity of natural gas is about six-tenths, air being considered as one. Corrections for exact specific gravity of gas may also be made if desirable.

The volume of gas flowing from a well or through a pipe is expressed

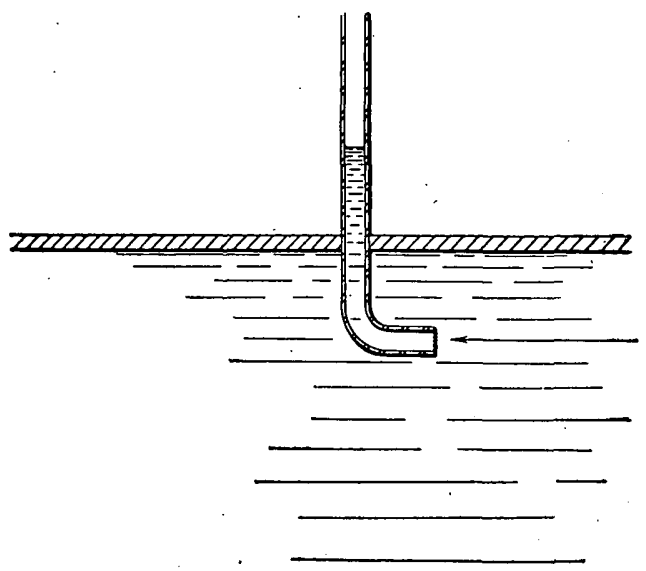

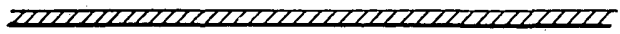

FIG. 8.-Simple form of Pitot tube.

in cubic feet. When a measurement is made, the size of the inside diameter of the pipe should be stated. This is because the carrying capacity of pipes varies as a square root of the fifth power (that is, as a 2.5 power) of the diameter, and although there is an increase in the velocity of flow with a decrease in size of the pipe, this does not entirely compensate for the increased friction. The tables comimonly used in computing volumes are apt to be misleading if this fact is not borne in mind, for in measuring the volume, the well tubing is usually reduced to a 2 -inch nipple. If it is desirable to determine the full capacity of a well, measurements should be made in the tubing.

As a result of friction currents the velocity of flow is not uniform over all parts of the area of a well opening. Experiments have shown that the points of mean velocity are about midway between the center and the circumference of the casing. In measuring the volume of gas issuing, it is necessary to determine its velocity and compute the 
amount for the size of the pipe. For measuring the velocity, the Pitot tube is employed. ${ }^{a}$

The simplest form of this instrument is shown in fig. 8 , in which the velocity of flowing water is shown to cause a rise of head in the tube. In accordance with the laws of physics (and as may be found by experiments) the height of the column is doubled when the velocity is squared.

The velocity of gas flowing from a well may also be determined by means of a spring gage in accordance with the following facts: The pressure required to drive a unit amount of gas through an opening must be increased fourfold for twice the amount of gas, since double the amount must pass in a given time and the unit amount must move with double the speed. Inasmuch as the density of the gas at the level of the casing is constant, being that produced by atmospheric pressure, the relative velocity may be determined by measuring the pressure, and is found to be doubled. when the pressure is four times as great. The method of using a spring gage is illustrated in fig. 9 .

Actual measurements may be made by means of volumetric meters. Such will furnish the basis for computing vol-

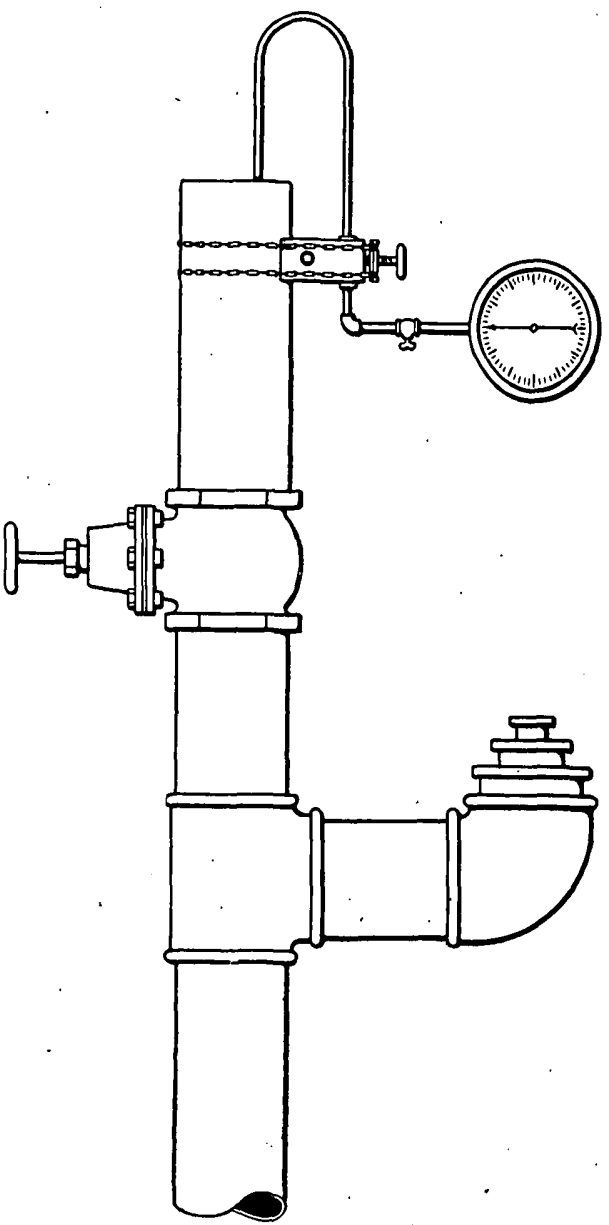

Fig. 9.-Pitot tube and spring gage attached for measuring velocity of gas issuing from a well. umes by means of velocity and pressure, and will show that they check very closely with the volumes computed from observations made with gages. A table, known as the Robinson table, in common use for computing the discharge of gas wells, is inserted here for reference.

a This instrument takes its name from the inventor, Pitot, who made it known to the French Academy of Sciences in 1732. Its adaptability for measuring the flow of gas was demonstrated by Prof. S. W. Robinson of the Ohio State University, who, by careful experimental tests, proved that the results obtained by it agree with the theoretical ones, while the instrument may be either fine or rude in construction. See Van Nostrand's Engineering Magazine, vol. 18; Geol. Survey Ohio, vol, 6, 1888; and First Ann, Rept. Geol. Survey, Ohio, 1890.

Bull, 238-04-4 
Pressure and flow in pipes. - The volume of gas flowing through a pipe at any point may be measured by determining the velocity and internal pressure of the gas. The Pitot tube is adapted to this use, and can be inserted into the flowing gas at the point of average velocity by drilling a hole in the pipe and making tight connection (fig. 10). The reading on the gage will be the pressure due to velocity plus the internal pressure. The internal pressure, which must be substracted

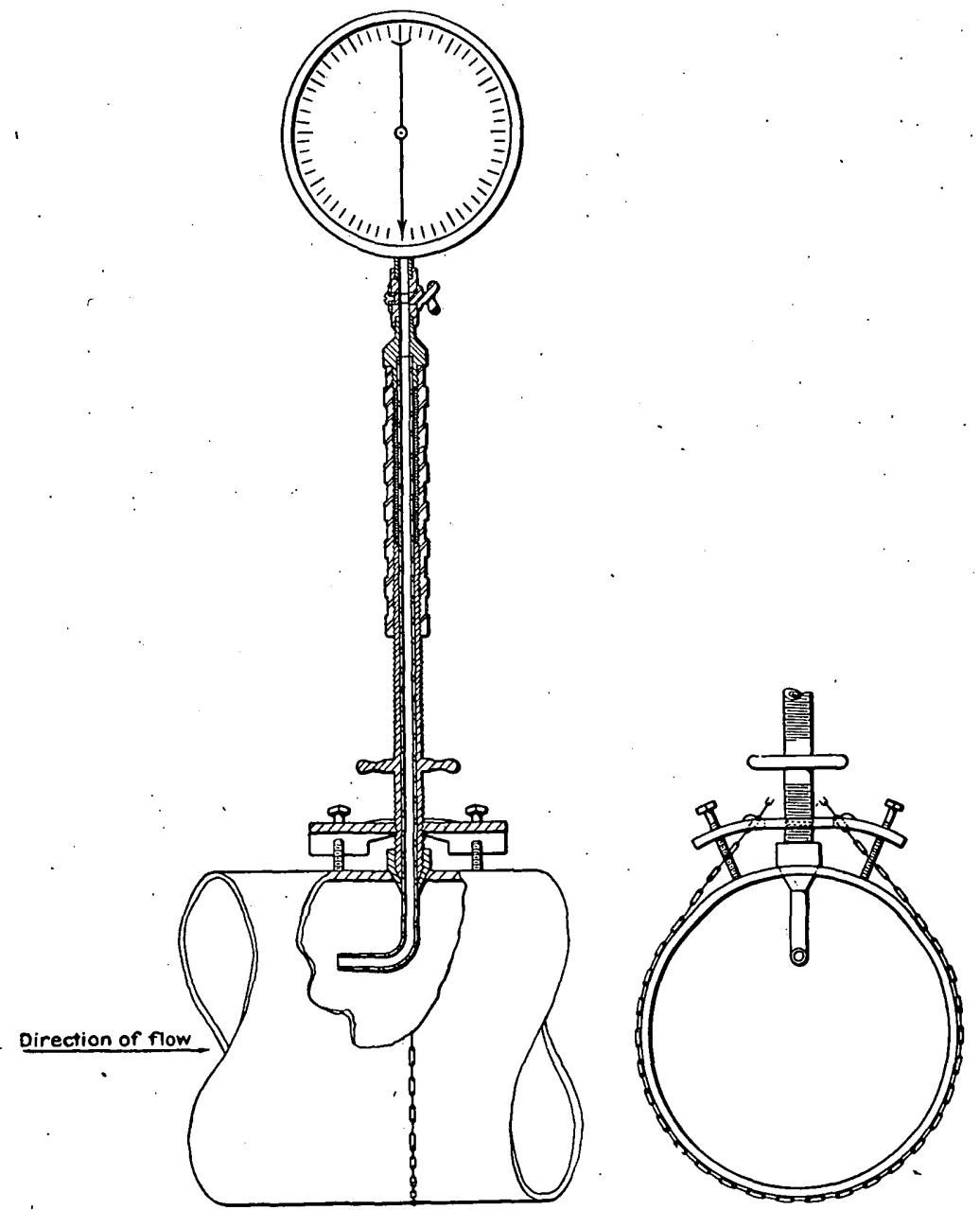

FIG. 10.-Pitot tube and spring gage, attached.for measuring velocity of flow of gas in a pipe.

in order to determine the pressure due to velocity, can be measured by connecting a spring gage or $U$-shaped tube in a similar manner, but so arranged that it records only the pressure transmitted laterally (see fig. 11). If the apparatus is arranged as in fig. 12, the reading on the gage will be the difference of the two, or the pressure due to velocity of flow. 'This form of instrument is known as the Robinson instrument. It may be used with spring gages, or, by detaching the 
TABLE I.-Cubic feet of gas discharged by gas well per day

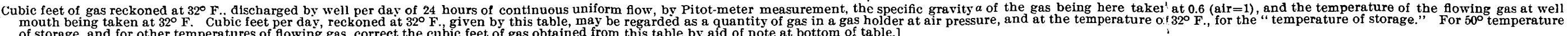

\begin{tabular}{|c|c|c|c|c|c|c|c|c|c|c|c|c|c|}
\hline \multirow{2}{*}{$\begin{array}{l}\text { bserved pres- } \\
\text { sure by mer- } \\
\text { cury gage. }\end{array}$} & \multirow{2}{*}{$\begin{array}{l}\text { Observed pres- } \\
\text { sure by water } \\
\text { gage. }\end{array}$} & \multirow{2}{*}{$\begin{array}{l}\text { Observed pres- } \\
\text { sure by pres- } \\
\text { sure gage. }\end{array}$} & \multicolumn{11}{|c|}{ Cubic feet of gas discharged. } \\
\hline & & & 1 in. diameter. & $1 \frac{1}{9}$ in. diameter. & 2 in. diameter. & $2 \frac{1}{\frac{1}{3}}$ in. diameter. & 3 in. diameter. & $3 \frac{1}{1}$ in. diameter. & 4 in. diameter. & $4 \frac{4}{2}$ in. dismeter. & 5 in. diameter. & $5 \frac{5}{8}$ in. diameter. & 6 in. diameter. \\
\hline Inches. & $\begin{array}{l}\text { Inches. } \\
0.10\end{array}$ & $\begin{array}{c}\text { Lbs. per sq.in. } \\
\quad 0.0036\end{array}$ & 12,390 & 27,880 & 49,556 & 77,440 & 111,510 & 151,780 & 198,220 & 250,890 & 309,750 & 392,000 & 446,040 \\
\hline & .20 & .0073 & 17,560 & 39,510 & 70,260 & 109,750 & 158,040 & 215,110 & 281,040 & 355,590 & 439,000 & 555,910 & 632,160 \\
\hline & .30 & .0109 & 21,480 & 48,330 & 85,940 & 134,250 & 193,320 & 263,130 & 343,760 & 434,970 & 537,000 & 679,630 & 773,280 \\
\hline & .50 & .0182 & 27,720 & 62,370 & 110,880 & 173,250 & 249,480 & 339,570 & 443,520 & 561,330 & 693,000 & 877,080 & 997,920 \\
\hline 0.05 & .70 & .0254 & 32,820 & 73,840 & 131,260 & 205,100 & 295,380 & 402,000 & 525,050 & 664,610 & 820,400 & $1,038,500$ & $1,181,520$ \\
\hline .07 & 1.00 & .0364 & 39,210 & 88,230 & 156,830 & 245,100 & 352,890 & 480,400 & 627,310 & 794,030 & $980 ; 400$ & $1,240,700$ & $1,411,600$ \\
\hline .11 & 1.50 & .0545 & 48,030 & $.108,070$ & 192,120 & 300,200 & 432,270 & 588,400 & 768,480 & 972,600 & $1,200,800$ & $1,517,900$ & $1,729,100$ \\
\hline .15 & 2.00 & .0727 & 55,340 & 124,520 & 221,360 & 345,900 & 498,060 & 677,960 & 885,440 & $1,120,600$ & $1,383,600$ & $1,751,000$ & $1,992,200$ \\
\hline .22 & 3.00 & .1090 & 67,910 & 152,800 & 271,630 & 424,500 & 611,190 & 832,020 & $1,086,510$ & $1,375,200$ & $1,698,000$ & $2,148,800$ & $2,444,800$ \\
\hline .29 & 4.00 & .1450 & 78,410 & 176,420 & 313,660 & 490,100 & 705,690 & 960,600 & $1,254,620$ & $1,587,800$ & $1,960,400$ & $2,480,900$ & $2,822,800$ \\
\hline .37 & 5.00 & .1820 & 87,670 & 197,260 & 350,670 & 548,400 & 789,030 & $1,074,860$ & $1,402,670$ & $1,775,310$ & $2,193,600$ & $2,733,900$ & $3,156,100$ \\
\hline .52 & 7.00 & .2540 & 103,500 & 232,880 & 414,000 & 646,900 & 931,500 & $1,267,900$ & $1,656,000$ & $2,095,900$ & $2,587,600$ & $3,274,800$ & $3,726,000$ \\
\hline .74 & 10.00 & .3636 & 123,000 & 276,750 & 492,000 & 768,800 & $1,107,000$ & $1,506,700$ & $1,968,000$ & $2,490,800$ & $3,075,000$ & $3,890,900$ & $4,428,000$ \\
\hline 1. 02 & 13. 75 & .5000 & 146,220 & 328,990 & 584,880 & 913,880 & $1,316,000$ & $1,791,200$ & $2,339,500$ & $2,760,900^{\circ}$ & $3,655,500$ & $4,626,500$ & $5,864,000$ \\
\hline 1.. 52 & 20.62 & .7500 & 175,350 & 394,540 & 701,400 & $1,096,000$ & $1,578,150$ & $2,148,160$ & $2,805,600$ & $3,550,900$ & $4,384,000$ & $5,548,200$ & $6,312,600$ \\
\hline 2. 03 & 27.50 & 1.0000 & 201,800 & 454,010 & 807,200 & $1,261,200$ & $1,816,050$ & $2,471,900$ & $3,228,500$ & $4,086,100$ & $5,044,600$ & $6,384,600$ & $7,264,200$ \\
\hline 3. 05 & 41.25 & 1.5000 & 247,840 & 557,650 & 991,370 & $1,549,000$ & $2,231,000$ & $3,036,000$ & $3,965,000$ & $5,019,000$ & $6,196,000$ & $7,842,000$ & $8,922,000$ \\
\hline 4.07 & 55.00 & 2.0000 & 285,130 & 641,540 & $1,140,500$ & $1,782,000$ & $2,566,200$ & $3,493,000$ & $4,562,000$ & $5,774,000$ & $7,128,000$ & $8,921,000$ & $10,265,000$ \\
\hline 5.08 & 68.75 & 2.5000 & 316,500 & $.712,130$ & $1,266,000$ & $1,978,000$ & $2,848,500$ & $3,877,000$ & $5,064,000$ & $6,409,000$ & $7,913,000$ & $10,014,000$ & $11,394,000$ \\
\hline 6.10 & 82.50 & 3. 0000 & 344,350 & 774,780 & $1,377,400$ & $2,152,000$ & $3,099,100$ & $4,218,000$ & $5,510,000$ & $6,973,000$ & $8,609,000$ & $10,895,000$ & $12,397,000$ \\
\hline 7.12 & 96.25 & 3.5000 & 370,000 & 832,500 & $1,480,000$ & $2,313,000$ & $3,330,000$ & $4,532,500$ & $5,920,000$ & $7,493,000$ & $9,250,000$ & $11,707,000$ & $13,320,000$ \\
\hline 8.13 & 110.00 & 4.0000 & 393,000 & 884,250 & $1,572,000$ & $2,456,000$ & $3,537,000$ & $4,814,200$ & $6,288,000$ & $7,958,000$ & $9,825,000$ & $12,435,000$ & $14,148,000$ \\
\hline 8.15 & & 4. 5000 & 415,270 & 934,350 & $1,661,100$ & $2,595,000$ & $3,737,400$ & $5,087,000$ & $6,644,000$ & $8,409,000$ & $10,382,000$ & $13,139,000$ & $14,950,000$ \\
\hline 10.17 & & 5.0000 & 436,200 & 981,450 & $1,744,800$ & $2,726,000$ & $3,925,800$ & $5,343,000$ & $6,979,000$ & $8,833,000$ & $10,905,000$ & $13,802,000$ & $15,703,000$ \\
\hline 11.18 & & 5. 5000 & 456,200 & $1,026,500$ & $1,824,800$ & $2,851,300$ & $4,105,900$ & $5,589,000$ & $7,299,000$ & $9,238,000$ & $11,405,000$ & $14,435,000$ & $16,423,000$ \\
\hline 12.20 & & 6.0000 & 473,750 & 1,$065 ; 900$ & $1,895,000$ & $2,961,000$ & $4,264,000$ & $5,803,000$ & $7,580,000$ & $9,593,000$ & $11,844,000$ & $14,990,000$ & $1 \overline{7}, 055,000$ \\
\hline 13.21 & & 6.5000 & 489,840 & $1,102,100$ & $1,959,400$ & $3,062,000$ & $4,409,000$ & $6,001,000$ & $7,837,000$ & $9,919,000$ & $12,246,000$ & $15,499,000$ & $17,634,000$ \\
\hline 14. 23 & & 7.0000 & 505,920 & $1,138,300$ & $2,023,700$ & $3,162,000$ & $4,553,300$ & 6,$198 ; 000$ & $8,095,000$ & $10,245,000$ & $12,648,000$ & $16,008,000$ & $18,213,000$ \\
\hline 15.25 & & 7.5000 & 522,010 & $1,174,500$ & $2,088,000$ & $3,263,000$ & $4,698,000$ & $6,395,000$ & $8,353,000$ & $10,571,000$ & $13,050,000$ & $16,517,000$ & $18,792,000$ \\
\hline 16. 26 & & 8.0000 & 538,500 & $1,21.1,600$ & $2,154,000$ & $3,366,000$ & $4,846,000$ & $6,597,000$ & $8,616,000$ & $10,905,000$ & $13,462,000$ & $17,038,000$ & $19,386,000$ \\
\hline 18.30 & & 9:0000 & 565,970 & $1,273,200$ & $2,263,000$ & $3,537,000$ & $5,093,000$ & $6,932,000$ & $9,054,000$ & $11,459,000$ & $14,147,000$ & $17,905,000$ & $20,371,000$ \\
\hline 20.33 & -. & 10.0000 & 589,270 & $1,325,900$ & $2,357,100$ & $3,683,000$ & $5,303,000$ & $7,219,000$ & $9,428,000$ & $11,933,000$ & $14,372,000$ & $18,645,000$ & $21,214,000$ \\
\hline 24.39 & & 12. 0000 & 633,340 & $1,425,000$ & $2,533,300$ & $3,958,000$ & $5,700,000$ & $7,758,000$ & $10,133,000$ & $12,825,000$ & $15,833,000$ & $20,040,000$ & $22,800,000$ \\
\hline 28.46 & .. & 14. 0000 & 675,000 & $1,508,800$ & $2,700,000$ & $4,219,000$ & $6,075,000$ & $8,269,000$ & $10,800,000$ & $13,669,000$ & $16,875,000$ & $21,357,000$ & $24,300,000$ \\
\hline 32.53 & & 16. 0000 & 713,550 & $1,605,500$ & $2,854,200$ & $4,459,700$ & $6,422,000$ & $8,741,000$ & $11,415,000$ & $14,449,000$ & $17,839,000$ & $22,577,000$ & $25,688,000$ \\
\hline 36.60 & & 18. 0000 & 748,650 & $1,684,500$ & $2,994,600$ & $4,679,000$ & $6,738,000$ & $9,1.51,000$ & $11,978,000$ & $15,160,000$ & $18,716,000$ & $23,977,000$ & $26,951,000$ \\
\hline 40.66 & & 20.0000 & 779,350 & $1,753,500$ & $3,117,400$ & $4,871,000$ & $7,014,000$ & $9,546,000$ & $12,470,000$ & $15,782,000$ & $19,484,000$ & $24,659,000$ & $28,057,000$ \\
\hline 50.81 & & 25.0000 & 845,150 & $1,901,600$ & $3,381,000$ & $5,282,000$ & $7,606,000$ & $10,353,000$ & $13,522,000$ & $17,114,000$ & $21,129,000$ & $26,741,000$ & $30,425,000$ \\
\hline 61.00 & & 30.0000 & 902,180 & $2,029,900$ & $3,609,000$ & $5,639,000$ & $8,120,000$ & $11,054,000$ & $14,435,000$ & $18,269,000$ & $22,555,000$ & $28,894,000$ & $32,478,000$ \\
\hline 71.16 & & 35. 0000 & 954,820 & $2,148,300$ & $3,819,000$ & $5,968,000$ & $8,593,000$ & $11,697,000$ & $15,277,000$ & $19,335,000$ & $23,870,000$ & $30,211,000$ & $34,373,000$ \\
\hline & & 40.0000 & 998,680 & $2,247,000$ & $3,995,000$ & $6,242,000$ & $8,988,000$ & $12,234,000$ & $15,979,000$ & $20,223,000$ & $24,967,000$ & $31,599,000$ & $35,952,000$ \\
\hline & & 45.0000 & $1,036,700$ & $2,332,600$ & $4,147,000$ & $6,479,000$ & $9,330,000$ & $12,700,000$ & $16,587,0 \mathrm{co}$ & $20,993,000$ & $25,918,000$ & $32,802,000$ & $37,321,000$ \\
\hline & & 50.0000 & $1,072,000$ & $2,412,000$ & $4,288,000$ & $6,700,000$ & $9,648,000$ & $13,132,000$ & $17,152,000$ & $21,708,000$ & $26,800,000$ & $33,919,000$ & $38,592,000$ \\
\hline & & 55.0000 & $1,106,880$ & $2,495,000$ & $4,428,000$ & $6,918,000$ & $9,962,000$ & $13,539,000$ & $17,710,000$ & $22,454,000$ & $27,672,000$ & $35,023,000$ & $39,848,000$ \\
\hline & & 60.0000 & $1,137,600$ & $2,559,600$ & $4,550,000$ & $7,110,000$ & $10,238,000$ & $13,935,000$ & $18,101,000$ & $23,036,000$ & $28,440,000$ & $36,000,000$ & $40,953,000$ \\
\hline
\end{tabular}

a To change results by this table to those for any other specific gravity of gas than 0.6, multiply by $\sqrt{\frac{0.6}{\text { sp. gr. gas. }}}$

NoTE.-For temperature of flowing gas where observed of $30^{\circ}, 40^{\circ}, 50^{\circ}, 60^{\circ} \mathrm{F}$., add 4, 3, 2, 1 per cent., respectively.

Should 98 per cent alcohol be used in gage, multiply the readings by 0.8 to reduce to water value. 


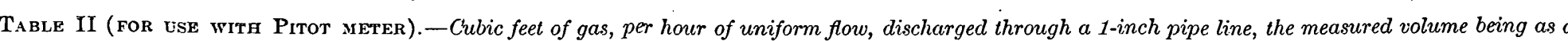

\begin{tabular}{|c|c|c|c|c|c|c|c|c|c|c|c|c|c|c|c|c|c|c|c|c|c|c|c|c|c|c|c|c|c|c|c|}
\hline \multicolumn{3}{|c|}{ Pitot meter manometer. } & \multirow{3}{*}{$\begin{array}{l}0 \\
0 \\
0 \\
0\end{array}$} & \multirow{3}{*}{$\begin{array}{l}0.63 \\
8.60 \\
.50 \\
.31\end{array}$} & \multirow{3}{*}{$\begin{array}{r}1.26 \\
17.20 \\
10.00 \\
.625\end{array}$} & \multirow{3}{*}{$\begin{array}{c}1.91 \\
26.00 \\
15.00 \\
.94\end{array}$} & \multirow{3}{*}{$\begin{array}{l}2.57 \\
35.00 \\
20.00 \\
1.25\end{array}$} & \multirow{3}{*}{$\begin{array}{r}3.82 \\
52.00 \\
30.00 \\
1.575\end{array}$} & \multirow{3}{*}{$\begin{array}{l}5.07 \\
69.00 \\
40.00 \\
2.50\end{array}$} & \multirow{3}{*}{$\begin{array}{c}7.65 \\
104.00 \\
60.00 \\
3.75\end{array}$} & \multirow{3}{*}{$\begin{array}{r}10.11 \\
138.00 \\
80.00 \\
5.00\end{array}$} & \multirow{3}{*}{$\begin{array}{c}20.22 \\
25.00 \\
160.00 \\
10.00\end{array}$} & \multirow{3}{*}{$\begin{array}{r}30.37 \\
413.00 \\
240.00 \\
15.00\end{array}$} & & $\begin{aligned} 50.55 \\
688.00\end{aligned}$ & 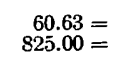 & $\begin{array}{l}\text { Static p } \\
\text { static } \\
\text { p }\end{array}$ & $\begin{array}{l}\text { surue of of } \\
\text { sure of }\end{array}$ & $\begin{array}{l}\text { Howing } \\
\text { Howing }\end{array}$ & $\begin{array}{l}\text { e pip } \\
\text { e pip }\end{array}$ & $\begin{array}{l}\text { ine, in in } \\
\text { ne, in in }\end{array}$ & $\begin{array}{l}\text { eles of colut } \\
\text { es of colur }\end{array}$ & $\begin{array}{l}\text { no nof mercl } \\
\text { no of water }\end{array}$ & $\begin{array}{l}\text { ury gage. } \\
\text { r gage. }\end{array}$ & & & & & & & \\
\hline Mercury & Water & Alcohol & & & & & & & & & & & & 320.00 & 400.00 & 485.00 & 560 & ${ }_{640}^{6}$ & 800 & 960 & 1,120 & 1,280 & $1,600=0$ & Dunces of ga & age pressu & re of gas $A_{0}$ & owing in pi & ipe line. & & & \\
\hline reading. & readiding. & reading. & & & & & & & & & & & & 20.00 & 25.00 & 30.00 & 35 & 40 & 50 & 60 & 70 & so & 100 & 120 & 140 & 160 & 180 & 200 & 220 & 240 & 260 pounds. \\
\hline Inches. & Inches. & Inches. & & & & & & & & & & & & & & & & & & & & & & & & & & & & & \\
\hline & $\begin{array}{l}0.02 \\
04\end{array}$ & $\begin{array}{r}0.025 \\
050\end{array}$ & 239 & $\begin{array}{r}242 \\
342\end{array}$ & 244 & 247 & 249 & 254 & 259 & 268 & 276 & 309 & 339 & 366 & 392 & $\begin{array}{r}415 \\
5\end{array}$ & 437 & $\begin{array}{l}458 \\
668\end{array}$ & 498 & $\begin{array}{c}535 \\
756\end{array}$ & $\begin{array}{c}569 \\
806\end{array} \mid$ & 602 & $\begin{array}{r}663 \\
993\end{array}$ & $\begin{array}{r}.717 \\
1014\end{array}$ & $\begin{array}{r}768 \\
1088\end{array}$ & $\begin{array}{r}816 \\
1154\end{array}$ & $\begin{array}{r}861 \\
861\end{array}$ & $\begin{array}{r}905 \\
1.280\end{array}$ & $\begin{array}{r}946 \\
1.38\end{array}$ & $\begin{array}{r}985 \\
1.94\end{array}$ & 1,024 \\
\hline & .06 & .075 $.075 x-30$ & $\begin{array}{l}323 \\
415\end{array}$ & $\begin{array}{l}342 \\
419\end{array}$ & $\begin{array}{l}345 \\
423\end{array}$ & $\begin{array}{l}349 \\
428\end{array}$ & $\begin{array}{l}353 \\
432\end{array}$ & $\begin{array}{l}359 \\
440\end{array}$ & $\begin{array}{l}366 \\
448\end{array}$ & $\begin{array}{l}379 \\
464\end{array}$ & $\begin{array}{r}391 \\
479\end{array}$ & $\begin{array}{l}437 \\
535\end{array}$ & $\begin{array}{l}479 \\
586\end{array}$ & $\begin{array}{l}517 \\
633\end{array}$ & $\begin{array}{c}552 \\
680\end{array}$ & $\begin{array}{l}586 \\
718\end{array}$ & $\begin{array}{l}618 \\
757\end{array}$ & $\begin{array}{l}648 \\
794\end{array}$ & $\begin{array}{l}704 \\
863\end{array}$ & $\begin{array}{l}756 \\
927\end{array}$ & $\begin{array}{l}800 \\
987\end{array}$ & $\begin{array}{r}802 \\
1,063\end{array}$ & $\begin{array}{r}r, 148 \\
1,148\end{array}$ & $\begin{array}{l}1,014 \\
1,242\end{array}$ & $\begin{array}{l}1,088 \\
1,338\end{array}$ & $\begin{array}{l}1,154 \\
1,414\end{array}$ & $\begin{array}{l}1,219 \\
1,492\end{array}$ & $\begin{array}{l}1,280 \\
1,567\end{array}$ & $\begin{array}{l}1,638 \\
1, \quad-100\end{array}$ & $\begin{array}{l}1,707 \\
1,787\end{array}$ & $\begin{array}{l}1,771 \\
1,773\end{array}$ \\
\hline & .08 & .100 & 479 & 484 & 488 & 493 & 498 & 508 & 517 & 535 & 553 & 618 & 677 & 731 & 782 & 829 & 874 & 916 & 996 & 1,070 & 1,139 & 1,204 & 1,325 & 1,434 & 1,539 & 1,633 & 1,724 & 1,809 & 1,892 & 1,971 & 2,047 \\
\hline & .10 & .125 & 535 & 541 & 546 & 552 & 557 & 568 & 578 & 598 & 618 & 691 & 757 & 818 & 874 & 927 & 977 & 1,025 & 1,114 & 1,196 & $1,25 t_{1}$ & 1,347 & 1,482 & 1,603 & 1,717 & 1,825 & 1,927 & 2,024 & 2,115 & 2,204 & 2,288 \\
\hline & .15 & .187 & 655 & 662 & 669 & 676 & 690 & 695 & 708 & 733 & 757 & 846 & 927 & 1,001 & 1,070 & 1,135 & 1,196 & 1,255 & 1,364 & 1,466 & $1,560^{\circ}$ & 1,649 & 1,814 & 1,963 & 2,104 & 2,236 & 2,360 & 2,478 & 2,590 & 2,699 & 2,803 \\
\hline & .20 & .250 & 757 & 765 & 772 & 780 & 787 & 802 & 818 & 846 & 874 & 977 & 1,070 & 1,156 & 1,236 & 1,311 & 1,381 & 1,449 & 1,576 & 1,692 & 1,802 & 1,904 & 2,096 & 2,267 & 2,430 & 2,582 & 2,725 & 2,861 & 2,991 & 3,116 & 3,236 \\
\hline & .25 & .312 & 846 & 855 & 863 & 872 & 880 & 897 & 914 & 946 & 977 & 1,093 & 1,197 & 1,292 & $\begin{array}{l}1,382 \\
1,3\end{array}$ & $\begin{array}{l}1,465 \\
\text {. }\end{array}$ & 1,544 & 1,620 & 1,761 & 1,892 & 2,013 & $.2,129$ & 2,343 & 2,535 & 2,718 & 2,886 & 3,047 & 3,199 & 3,344 & 3,484 & 3,618 \\
\hline & .30 & .375 & 927 & 936 & 946 & 955 & 965 & 983 & 1,001 & 1,036 & 1,070 & 1,197 & 1,310 & 1,461 & 1,514 & 1,605 & 1,692 & 1,775 & 1,929 & 2,072 & 2,206 & 2,332 & 2,566 & 2,777 & 2,975 & 3,162 & 3,337 & 3,505 & 3,664 & 3,816 & 3,963 \\
\hline & .40 & .500 & 1,070 & 1,081 & 1,092 & 1,103 & 1,114 & 1,135 & 1,156 & 1,201 & 1,235 & 1,382 & 1,513 & 1,635 & 1,748 & 1,854 & 1,954 & 2,049 & 2,228 & 2,393 & 2,548 & 2,693 & 2,963 & 3,028 & $3 ; 436$ & 3,651 & 3,854 & 4,047 & 4,230 & 4,407 & 4,577 \\
\hline & 50 & 625 & 1,196 & 1,209 & 1,223 & 1,233 & 1,242 & 1,269 & 1,292 & 1,338 & 1,381 & 1,545 & 1,692 & 1,828 & 1,954 & 2,072 & 2,184 & 2,291 & 2,490 & 2,675 & 2,848 & 3,011 & 3,313 & 3,585 & 3,844 & 4,082 & 4, 309 & 4,524 & 4,730 & $4,92 \pi$ & 5,117 \\
\hline & 60 & .750 & 1,311 & $1 ; 323$ & 1,338 & 1,351 & & & 1,461 & 1,468 & & & & & & 2,270 & 2,393 & & & 2,930 & & 3,298 & 3,630 & 3,928 & 4,208 & 4,472 & 4,720 & 4,956 & 5,181 & & 5,605 \\
\hline & .80 & 1.000 & 1,513 & 1,530 & 1,546 & 1,560 & 1,575 & 1,605 & 1,635 & 1,692 & & 1,954 & 2,140 & 2,312 & & 2,621 & 2,763 & 2,898 & & 3,384 & & 3,808 & 4,1 & 4,5 & 4,860 & 5,163 & 5,450 & 5,723 & 5,983 & 32 & 173 \\
\hline & 1.00 & 1.250 & 1,692 & 1,709 & 1,727 & 1,744 & 1,761 & 1,795 & 1,828 & 1,892 & 1,954 & 2,185 & 2,393 & 2,585 & 2,763 & 2,931 & 3,089 & 3,240 & 3,522 & 3,782 & 4,028 & 4,256 & 4,686 & 5,070 & 5,433 & 5,773 & 6,094 & 6,398 & 6,689 & 6,968 & 7,236 \\
\hline & 1. 20 & 1.500 & 1,853 & 1,871 & 1,875 & 1,911 & 1,929 & 1,966 & 2,002 & 2,076 & 2,140 & 2,393 & 2,621 & 2,831 & 3,027 & 3,210 & 3,384 & 3,549 & 3,858 & 4,144 & 4,412 & 4,664 & 5,133 & 5,554 & 5,951 & 6,323 & 6,675 & 7,009 & 7,328 & 7,633 & 7,927 \\
\hline 0.10 & 1.40 & 1.750 & 2,002 & 2,025 & 2,123 & 2,064 & 2,084 & 192 & 2,162 & 2,240 & 2,312 & 2,585 & 2,831 & & 3,269 & 3,468 & 3,699 & 3,834 & 4,168 & 4,476 & 4,768 & 5,036 & 5,544 & 5,999 & 6,428 & 6,830 & 7,210 & 7,570 & 7,915 & 8,245 & 8,562 \\
\hline .12 & 1.60 & 2.000 & 2,140 & 2,168 & 2,196 & 2,206 & 2,228 & 2,270 & 2,312 & 2,393 & 2,471 & 2,763 & 3,027 & 3,269 & 3,495 & 3,707 & 3,908 & $\mid \begin{array}{l}0 \\
4\end{array} 4,100$ & 4,456 & 4,784 & 5,096 & 5,384 & 5,926 & 6,413 & 6,879 & 7,302 & 7,708 & 8,093 & 8,462 & 8,814 & 54 \\
\hline .13 & 1.80 & 2. 250 & 2,270 & 2,291 & 2,324 & 2,340 & 2,363 & 2,408 & 2,454 & 2,538 & 2,621 & 2,931 & 3,210 & 3,420 & 3,707 & 3,932 & 4,144 & 4,348 & 4,724 & 5,076 & 5,404 & 5,700 & 6,286 & 6,802 & 7,289 & 7,744 & 8,175 & 8,584 & 8,974 & 9,348 & 9,709 \\
\hline .15 & 2.00 & & 2,393 & 2,409 & 2,456 & 2,466 & 2,490 & 2,538 & 2,585 & 2,676 & 2,763 & 3,089 & 3,384 & 3,656 & 3,908 & 4,144 & 4,368 & 4,584 & 4,980 & 5,352 & 5,696 & 6,020 & 6,626 & 7,170 & 7,683 & 8,164 & 8,618 & 9,049 & 9,460 & 9,854 & 10,236 \\
\hline .18 & 2.50 & 3. 120 & 2,675 & 2,702 & 2,740 & 2,758 & 2,784 & 2,837 & 2,890 & 2,975 & 3,089 & 3,455 . & 3,785 & 4,087 & 4,368 & 4,636 & 4,884 & 5,118 & 5,568 & 5,980 & 6,368 & 6,732 & 7,408 & 8,016 & 8,595 & 9,127 & 9,634 & 10,120 & 10,580 & 11,016 & 11,444 \\
\hline .22 & 3.00 & 3.750 & 2,931 & 2,958 & 3,000 & 3,021 & 3,050 & 3,108 & 3,166 & 3,277 & 3,384 & 3,784 & 4,144 & 4,477 & 4,784 & 5,184 & 5,352 & 5,612 & 6,100 & 6,552 & 6,976 & 7,376 & 8,115 & 8,781 & 9,409 & 9,998 & 10,554 & $11,084^{\circ}$ & 11,587 & 2,070 & 2,532 \\
\hline .29 & & & & & & & 3,5 & & 3,6 & 3,798 & & & 4,786 & 5,169 & & & 6,176 & 6,480 & 7,044 & & 8,056 & 8,516 & 9,370 & 10,143 & 10,865 & 11,544 & $\mid 12,188$ & 12,797 & 13,380 & & 1,470 \\
\hline .37 & & & & & & & & & 4,087 & & & & & & & & 6,908 & & & & & 9,520 & 10,474 & 11,340 & 12,155 & 12,908 & 13,515 & 14,314 & 14,964 & 15,580 & 6,180 \\
\hline .44 & 6.00 & & & & & & & & 4,477 & 4,643 & & 5,351 & 5,861 & & & 7,180 & 7,568 & 7,936 & 8,628 & 9,268 & $9,868 \mid$ & 10,428 & 11,477 & 12,420 & 13,304 & 140 & 14,925 & \begin{tabular}{|l|}
15,674 \\
\end{tabular} & 16,380 & 17,070 & 30 \\
\hline .59 & 8.00 & 10.000 & 4,786 & 4,838 & 4,886 & 4,933 & 4,918 & 5,076 & 5,169 & 5,351 & 5,526 & 6,179 & 6,796 & 7,310 & 7,816 & 8,288 & 8,736 & 9,164 & 9,964 & $|10,700|$ & 11,392 & 12,044 & 13,252 & 14,340 & 15,367 & 16,326 & 17,240 & 18,097 & 18,920 & 19,710 & 20,470 \\
\hline .74 & 10.00 & 12.500 & 5,357 & 5,407 & 5,461 . & & & & & & & & & & & & & & & & & & & $\mid 16,030$ & 17,180 & 18,255 & $\mid 19,270$ & 20,240 & 21,150 & 22,035 & \\
\hline .88 & & & & & & & & & & & & & & & & 10,153 & 10,701 & 1,226 & & 13,108 & 13,953 & 14,750 & 16,230 & 17,560 & 18,820 & 19,996 & 21,108 & $22,16 \bar{T}$ & 23,174 & 24,138 & 66 . \\
\hline 1. 10 & & 18.7 & 6,55 & & & & & & & & & & 9,2 & 10, & 10,6 & & 11,9 & 12,580 & 13,643 & 14,652 & 14,970 & 16,490 & & 19,635 & 21,040 & 22,357 & 23,600 & 24,780 & 25,900 & 26,990 & \\
\hline 1.47 & & & 7,567 & 7,6 & & 7,7 & 7,878 & 8,0 & 8,174 & 8,461 & 8,737 & 9,770 & 10,700 & 11,560 & 12,359 & $13,10 \overline{7}$ & 13,813 & 14,490 & 15,751 & 16,920 & 18,015 & 19,042 & 20,950 & 22,670 & 24,295 & 25,816 & 27,250 & 28,610 & 29,915 & 1,160 & 60 \\
\hline 1.84 & 25.00 & 31.250 & 8,461 & 8,544 & 8,661 & 8,721 & 8,802 & 8,972 & 9,138 & 9,460 & 9,768 & 10,925 & 11,970 & 12,920 & 13,815 & 14,651 & 15,445 & 16,200 & 17,611 & 18,919 & 20,140 & 21,290 & 23,427 & $25,350 \mid$ & 27,183 & 28,864 & 30,470 & 31,990 & 33,460 & 34,840 & 36,180 \\
\hline 2.21 & 30.00 & 37.500 & 9,268 & 9,354 & 9,488 & 9,558 & 9,645 & 9,829 & 10,010 & 10,365 & 10,700 & 11,965 & & & 15,135 & 16,053 & 16,921 & 17,750 & 19,292 & 20,721 & 2,061 & 23,320 & $25,660 \mid$ & 27,7 & 29,755 & 31,66 & 33,370 & 35,050 & 640 & 38,160 & 30 \\
\hline & & & & & & & & 11,350 & & & & & & & & & & & & & & & & & & & & & & & \\
\hline & & & & & & & 450 & 12, & 12, & & 13,814 & 15, & & 280 & 19,537 & 20,720 & 21,511 & 22,910 & 24,905 & $26 ; 753$ & 28,483 & 30,1 & 33,130 & & 38,4 & 40,820 & 43,0 & 45,240 & 320 & & 70 \\
\hline 4. 42 & & 75.500 & 106 & 13,233 & 13,4 & & 13,640 & 13,900 & 14,160 & 14,680 & 15,130 & 16,920 & 18,535 & 20,020 & 21,403 & 22,700 & 23,928 & 25,008 & $2 \bar{t}, 285$ & 29,305 & 31,201 & 32,980 & 36,300 & 39,280 & 42,080 & 44,720 & 47,200 & 49,560 & 51,810 & 53,980 & 56,050 \\
\hline 5.15 & 70.00 & 87.500 & 14,160 & 14,300 & 14,480 & 14,590 & 14,730 & 15,010 & 15,290 & 15,863 & 16,350 & 18,280 & 20,020 & 21,625 & 23,116 & 24,516 & $25,845$. & $27,109 \mid$ & $\mid 29,468$ & 31,653 & $33,700 \mid$ & 35,623 & $39,200 \mid$ & 42,420 & 45,453 & 48,300 & 50,980 & 53,530 & 55,970 & 58,300 & 59,712 \\
\hline 5. 89 & & & & & & & & & & 920 & 17,474 & 19,540 & & & & & & & & & 029 & & & & & & & & & & \\
\hline & & & & & & & & & & & & & & & & & & & & & & & 44 & 48,1 & 51,560 & 760 & & , & 460 & & 50 \\
\hline 7.36 & & & 920 & 17 , & 17,270 & 17,440 & & & 18,280 & 18,920 & $\begin{array}{l}10, \\
19,530\end{array}$ & 21,8 & 23,930 & $\begin{array}{l}2,4,020 \\
25,850\end{array}$ & & 29,308 & 30,890 & \begin{tabular}{|l|}
32,402 \\
\end{tabular} & & $\mid \begin{array}{l}30,80071 \\
37,8\end{array}$ & 40,280 & & 46,860 & 50,700 & 54,327 & 57,730 & 60,940 & 63,990 & 66,890 & 69,680 & 72,360 \\
\hline 8. 10 & 110.00 & 137.500 & 17,750 & 17,920 & 18,111 & 18,290 & 18,470 & 18,820 & 19,170 & 19,860 & 20,490 & 22,910 & 25,100 & 27,110 & 28,979 & 30,635 & 32; 402 & 33,980 & 36,940 & 39,670 & 42,248 & 44,670 & 49,140 & 53,170 & 57,070 & 60,544 & 63,910 & 67,110 & 70,150 & 73,080 & 75,892 \\
\hline
\end{tabular}

For any pipe larger than one inch, multiply value given by above table by the value under actual diameter as belor.

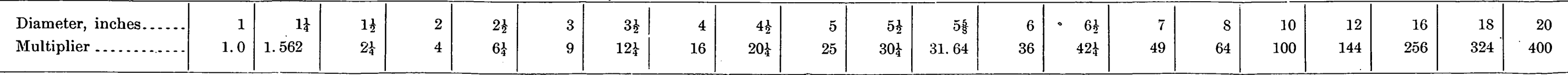

(air $=1$ ), multiply by $\sqrt{\frac{0.6}{\text { sp. g. g. gas. }}}$

Bull. 238-04. (To face page 50.) No. 2 . 

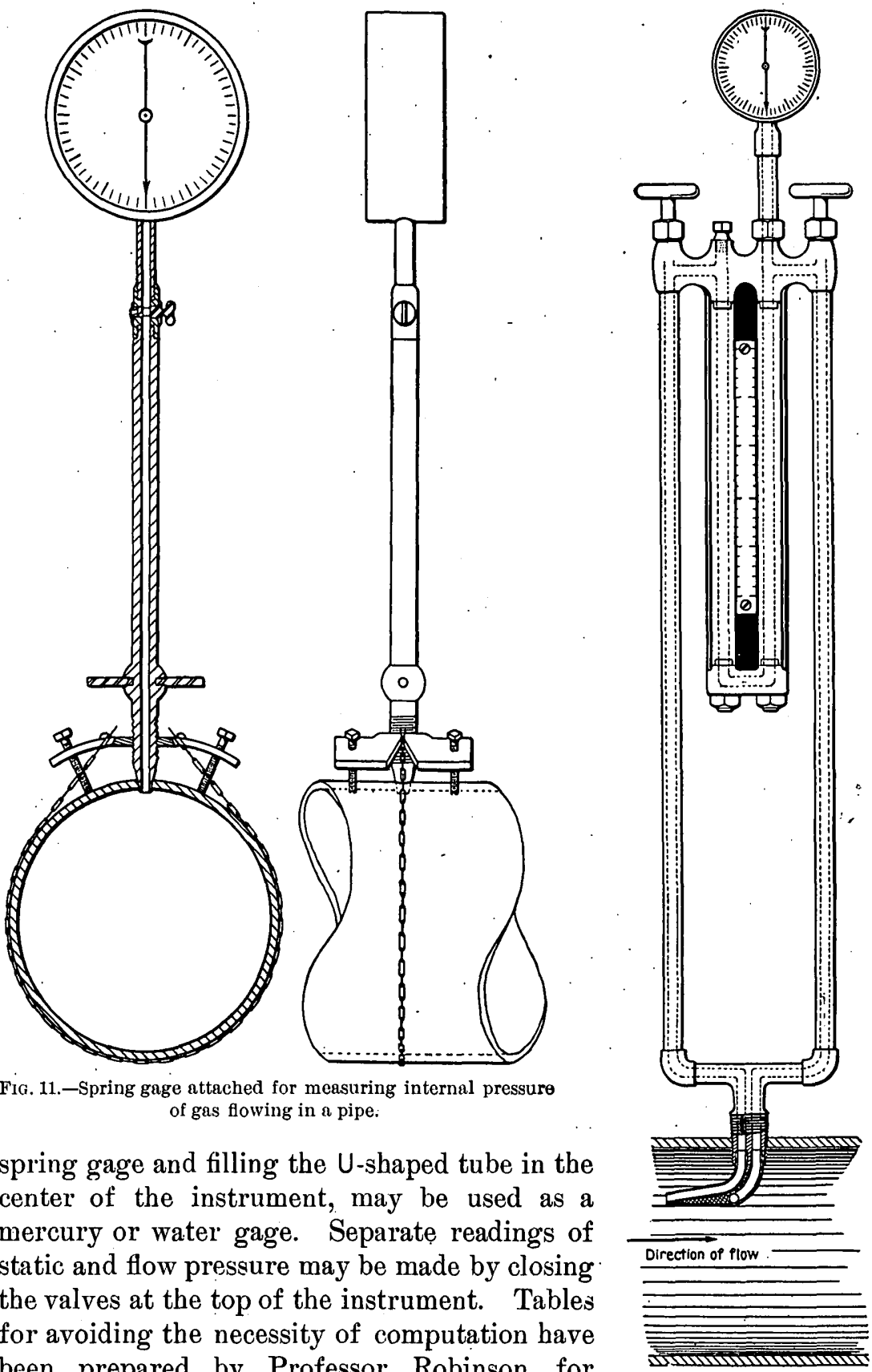

Fia. 11.-Spring gage attached for measuring internal pressure of gas flowing in a pipe.

spring gage and filling the $\mathrm{U}$-shaped tube in the center of the instrument, may be used as a mercury or water gage. Separate readings of static and flow pressure may be made by closing. the valves at the top of the instrument. Tables for avoiding the necessity of computation have been prepared by Professor Robinson for various sized pipes. Corrections may be made in these for difference in specific gravity and temperature.

FIG. 12.-Robinson instrument for measuring velocity and pressure of gas flowing in pipes.

Minute pressure, or measurement of volume by number of condensations. - If gas is allowed to flow into a reservoir of known capacity the 
amount which enters may be computed from the increase in internal pressure which accompanies increased density. The casing of a well affords opportunity for similar measurements. If a well is allowed to blow off and is then suddenly closed and the reading of the pressure gage is taken, the density of the gas in the casing at that instant may be determined. If the gage is watched the indicator will show a gradually higher pressure. If this is recorded at the end of a minute the amount of gas which has entered the well casing during that time may be computed by means of the difference in density, the volume of the casing being a readily determinable factor.

In measuring the volume of a well by this method a short piece of tube is attached to the well casing in the same manner as if the static pressure were to be taken, but is so arranged that the well can be blown off. To this tubing a spring or $U$ gage is attached. After the well has been blown off and the index of the gage is stationary the pressure is read and recorded. The control valve is then immediately closed and the time noted. At the end of a minute the pressure on the gage is read and recorded. It will be found to be higher as the result of the compression of the gas in the casing. The difference in pressure is multiplied by the volume of the well tubing in cubic feet and by 0.07 (the constant employed in calculating the number of compressions), and this product is the volume in cubic feet per minute. This quantity multiplied by 60 and 24 gives the volume of production for a day.

This method of measuring the volume of a gas well is the most convenient one yet devised, but although valuable as indicating the relative production which is possible from wells, it should not be considered as accurate.

For computing the volume of a well casing the following table will be found convenient:

Table of diameters in inches, and of contents in cubic feet, for 1 foot of length of well casing.

\begin{tabular}{|c|r||r|c|}
\hline $\begin{array}{c}\text { Diameter in } \\
\text { inches. }\end{array}$ & $\begin{array}{c}\text { Cubic feet for } \\
\text { 1-foot length. }\end{array}$ & $\begin{array}{c}\text { Diameter in } \\
\text { inches. }\end{array}$ & $\begin{array}{c}\text { cubic feet for } \\
\text { 1-foot length. }\end{array}$ \\
\hline 1 & 0.0055 & 6 & 0.1963 \\
2 & 0.0219 & 8 & 0.3491 \\
3 & 0.0491 & 10 & 0.5454 \\
4 & 0.0873 & 12 & 0.7854 \\
5 & 0.1364 & & \\
\hline
\end{tabular}


OBSERVATIONS AND MEASUREMENTS OF GAS WELLS.

By W. R. Crane.

Measurements of static, or closed, pressure. - The usual method of taking the closed or static pressure of a well when it is free from connecting tubes is to reduce the 2 - or 3 -inch valve opening by bushings and plugs to a size that will permit the attachment of a pressure gage (see fig. 4). Connection is usually made by a short section of quarterinch pipe, either straight or formed into a loop such as is commonly known as a steam siphon. If there is a $T$ in the casing below the control valve a lateral pipe valve and elbow will afford a convenient attachment for the gage. Sometimes a hole is drilled into the well tubing a few inches below the control valve, and is threaded, and a short piece of pipe with a valve and a gage connection screwed in. The last two forms of connection are especially convenient where measurements are taken frequently, since they may be left ready for the attachment of the gage. When a gage is attached to a well the joints should be tight. The valve leading to the gage should be opened slowly to prevent too sudden pressure being thrown on the gage. The pressure of the gas will cause the indicator to move until it records a maximum at which it will remain stationary. If the well has not been blown off this pressure will be reached as soon as the valves are fully opened. In case it has been blown off some time will be required for the gas to build up to maximum pressure. Before attempting to remove the gage the valves should be carefully closed. Since there is a wide range of pressures in gas wells, the observer is usually provided with several gages from which he selects one capable of recording the pressure found.

The record of the static pressure in a well is sometimes incorrectly interpreted as indicating the volume of a well. The relation between pressure and volume of flow is variable, and accordingly measurements of flow should be made when the capacity is to be estimated. The observations of static pressure which were taken in the Iola quadrangle were largely for the purpose of determining the hydrostatic conditions in the field and have been of great value in determining the structural relations of the gas-bearing strata.

In studying the hydrostatic conditions of a field it is desirable to learn the initial pressures of wells since they furnish data for estimating the head of water which is pressing upon the gas in a reservoir. When a well is drilled into a sand which has already been tapped by other wells the pressure which it shows is apt to be below that of the first well, since the using of the gas changes the relations in the reservoir. The initial pressures for different parts of the field were obtained from parties who had made observations at the beginning of 
developments. Some of the pressures have been recorded in published reports or are on record in notes of men who work in the field. The writer measured the pressure in wells in new parts of the field; some of his figures may be regarded as those of initial pressures, since the gas pools had not been drawn upon.

The pressure in the Iola quadrangle varies with the depth of the wells; in round numbers it is $330,290,270$, and 230 pounds for wells varying in depth between 900-950, 800-900, 700-800, and 600-700 feet, respectively. These figures agree remarkably well with the range of pressures taken throughout the entire field.

As a means of checking the pressure due to hydrostatic head in gas wells, some measurements were made from wells which produce oil. In these cases the pressure recorded was due to the compression of air and gas on top of the oil column when the well was closed. To the pressure shown by the gage was added the weight of a column of oil 1 square inch in section and equal in height to the depth of the oil in the well. An average of a number of measurements made on a group of oil wells showed a pressure of 7.3 pounds on the gage. In estimating the weight of the oil in the well the weight of a column 1 square inch in section and 1 foot high was taken at 0.348 pounds. The total column of oil in the wells in question was 799 feet, equal to 278.4 pounds. The observed pressure of 7.37 pounds added to this gives a total of 285.77 pounds as the hydrostatic pressure in the well. The hydrostatic pressure in gas wells close by which have the same depth was found to be 286.7 pounds. This shows a close correspondence, the difference being about 1 pound. Similar results have been obtained by other observers.

In parts of the field which have been drawn upon very largely the static pressure of wells is generally known to have fallen off. Data obtained during the progress of field work, compared with records made by the writer the previous summer and with the records of other observers, show the decrease to be gradual. Where the wells have been in use for a long time the pressure has been diminished until the consequent production is small, and in some cases the wells have been abandoned. Any notable decrease of static pressure is occasion for alarm as to the continuance of production from a given reservoir. The accompanying table, extending over a considerable period of time, bas been prepared from observations on certain wells in the Iola quadrangle. 
Table shoning decrease of static pressure in certain wells in a part of the Iola field where the consumption is very great.

\begin{tabular}{|c|c|c|c|c|c|c|c|c|c|c|c|}
\hline \multirow{2}{*}{ No. of well. } & \multicolumn{2}{|c|}{1900.} & \multicolumn{3}{|c|}{1901.} & \multicolumn{3}{|c|}{1902.} & \multicolumn{3}{|c|}{1903.} \\
\hline & Sept. & Dec. & Apr. & Aug. & Dec. & Apr. & Aug. & Dec. & Apr. & Aug. & Dec. \\
\hline & Pounds. & Pounds. & Pounds. & Pounds. & Pounds. & Pounds. & Pounds. & Poinds. & Pounds. & Pounds. & Pounds. \\
\hline 1. & 280 & 235 & 190 & 200 & 150 & 85 & 95 & 130 & 100 & 55 & \\
\hline 2 & 249 & $222^{\circ}$ & 185 & 170 & 165 & 130 & 150 & 75 & 65 & 60 & $\ldots$ \\
\hline 3. & 233 & 180 & 187 & 177 & 130 & 145 & 127 & $100^{\circ}$ & 85 & 70 & \\
\hline 4. & & 154 & 150 & 135 & 110 & 122 & 110 & 40 & 2.5 & 1.5 & \\
\hline $5 \ldots \ldots$ & ....... & 151 & Off. & 1.20 & 110 & 86 & 45 & 40 & Off. & & \\
\hline
\end{tabular}

The initial static pressures, as well as those judged to be somewhat below the initial, obtained from the gas wells in the Iola quadrangle, were platted upon a map, whence it appeared that the low pressures are in the eastern portion of the field and the high pressures in the western. Moreover, zones of equal or of given variation in pressure can be outlined. In the map (fig. 13) zones in which the pressure varies from 140 to 200 pounds, from 200 to 300 , and 300 to 330 pounds, are shown. From a consideration of the structure of the field and these zones of pressure the following deductions may be drawn:

1. The trend of the zone is approximately parallel with the strike of the rocks.

2. The pressure increases westward with the dip of the rocks and the static pressure in the wells varies directly with the distance from the outcrop of the gas-bearing formation.

3. The variation of pressure is greatest in pools farthest from the outcrop.

Measurement of the volume of gas wells.-An approximate estimate of the capacity of a gas well can be formed from the sound which the gas makes when it flows into the air. An experienced observer can come within 10,000 to 15,000 cubic feet of the total capacity, but is liable to make a wider error, especially if there are irregularities in the tubing or in the valve which affect the sound. Inasmuch as wells are sold on their purported capacities great care should be exercised in order to guard against misrepresentations. The most accurate method of measuring a well is by means of the Pitot tube (fig. 9). The essential part of this instrument is a U-shaped tube either in a continuous piece or formed by joining straight pieces of pipe by means of elbows. When a tube is made of straight pieces it can be taken apart and cleaned. This is a decided advantage, especially where wells are.throwing shale or mud which may clog up the tube. The instrument is attached to a block or saddle which in turn is fastened by means of chains at the top of the well casing. It should be placed at 
a distance from the control valve. The tube must be free to rotate in the saddle and should be so arranged that it can be adjusted to various sized pipes and brought to any required position over the mouth of the well. When a measurement is made the tube is clamped in the desired position by means of a set screw.

Various devices are employed for attaching the instrument. When a wooden block is used as a saddle it is hollowed at one end to fit the

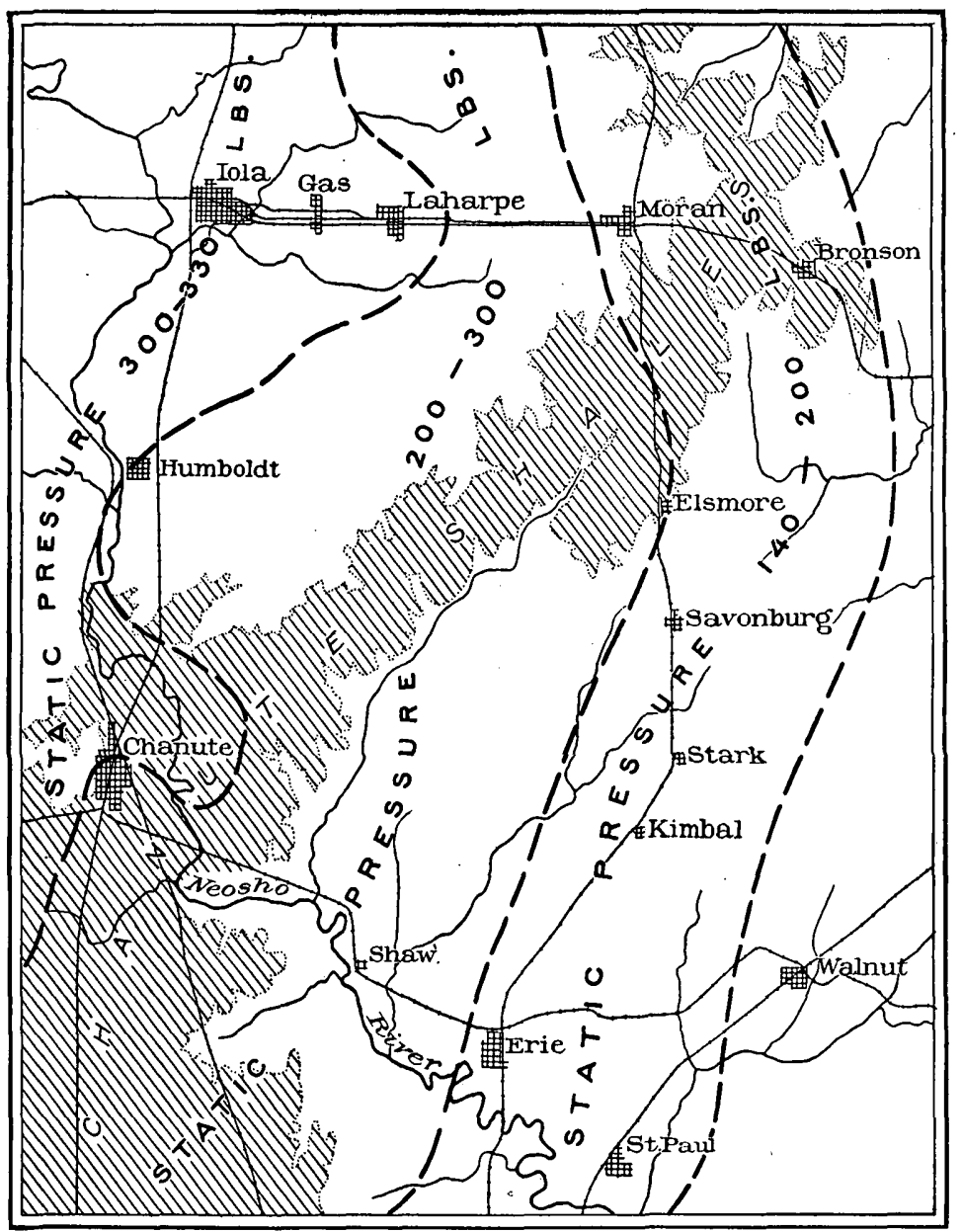

FIG. 13.-Map of Jola quadrangle, showing approximate zones of variation of static pressure of gas wells. The area of outcrop of the Chanute shale is indicated in order to show that the zones are approximately parallel with the strike of the geologic formations.

pipe and slotted longitudinally to allow the adjustment of the tube to the right position in the column of escaping gas. At the end of the block opposite the casing is attached a tightening arrangement operated by a screw. The chains which reach around the well casing are hooked into slots in the ends of a plate. After they have been drawn as tightly as possible about the casing, a few turns of the set screw sep- 
arate this plate from the block and make the instrument rigid on the well casing. At the end of the U-shaped tube, which is on the outside of the well casing, a pressure gage is attached by means of a flexible hose connection. For strong wells a spring gage is ordinarily used, and for wells having small capacity a gage containing mercury or other liquid is preferable. In adjusting a Pitot tube the mouth should be placed at about the middle of the radius of the casing, at which point the gas flows with a mean velocity. A slight variation in position at this point makes little or no difference, and with a small Pitot tube there is little chance of error.

When a measurement is to be taken the instrument should be attached to the mouth of the well and the tube swung to one side. The well is then allowed to blow off for a period, which varies somewhat with the capacity of the well, but seldom exceeds 4 to 6 minutes. When the accumulated head of gas has been spent the sound made by the gas issuing is uniform and the measurement may be taken. Often the well in blowing off must clear itself of water, mud, and pieces of shale. In such cases the observer must frequently wait 15 to 30 minutes. In rare instances there is no perceptible diminution of ejected material, and measurements are made with difficulty and are liable to be inaccurate, since the mud and shale and water interfere with the flow of the gas and are apt to clog the Pitot tube. When the flow of gas becomes uniform the Pitot tube is rotated over the mouth of the well and clamped in position at the level of the casing. If there is any doubt as to whether the well has blown off a sufticient length of time, the observer should note the register on the gage to see whether it varies, and in case it is found to do so he should wait until it is steady before taking the reading.

The capacity of a well for 24 hours is computed by means of tables which are in common use (see facing p. 50). In stating this capacity the size of the well casing or tubing should always be given, since the capacity varies with the size of the orifice.

The observations taken on wells in the Iola quadrangle show that the flow of gas at different places varies from a few thousand feet up to $10,000,000$ feet per day, an average good well flowing about $4,500,000$ feet per day. In general the stronger the static pressure of the well the greater the volume of production. Accordingly the best wells are situated in the western part of the area.

The maximum production of a gas well is reached as soon as it has been properly cased and has had an opportunity to clear itself of loose material. From then on it will show a gradual decrease in flow. A good gas well is free from water; the invasion of salt water lessens the value of the well and may entirely stop the issuance of the gas or render it so small as to be worthless. When many wells are drawing upon a reservoir of gas the volume falls off more rapidly, and 
as the flow decreases it is found necessary to connect more wells with the pipe line in order to obtain the desired amount.

The question which is of vital importance to the industries depending upon gas for fuel is that of the probable life of the field. Since there are undoubtedly_a number of gas reservoirs, the question resolves itself into the probable life of the individual reservoirs. Inasmuch as it is impossible to know the vertical and lateral extent of the gas sands, no computation for an individual field can be made on this basis. However, a case may be assumed which will give an idea of the probable life of a gas field. Supposing that a gas sand baving a thickness of 40 feet has an areal extent of a square mile, and that the static pressure of the gas is 300 pounds, we may measure the total amount of contained gas. Assuming that the gas occupies a pore or interstitial space in the sand equal to 38 per cent of the total volume (which is a very liberal estimate), 2.6 cubic feet of the sand would contain 1 cubic foot of gas at a pressure of 300 pounds, or 12.36 cubic feet of sand would contain 100 cubic feet of gas at atmospheric pressure. An area of sand 1 foot in thickness and having an extent equal to 1 acre would contain 43,560 square feet of gas at atmospheric pressure. If the sand is 40 feet thick and has the same extent, it contains $14,097,080$ cubic feet, and in a square mile of 640 acres there would be $9,022,131,200$ cubic feet of gas. To render this calculation more convenient for reference in computing for sands of various thickness and extent, the following table is presented:

Contents of gas under a pressure of 300 pounds per square inch in sands having 38 per cent pore space.

\begin{tabular}{|r|r|r|}
\hline $\begin{array}{c}\text { Thickness } \\
\text { of sands } \\
\text { in feet. }\end{array}$ & $\begin{array}{r}\text { Cubic feet per } \\
\text { gcre. }\end{array}$ & $\begin{array}{r}\text { Cubic feet per square } \\
\text { mile. }\end{array}$ \\
\hline 1 & 352,427 & $225,553,280$ \\
10 & $3,524,270$ & $2,255,532,800$ \\
20 & $7,048,540$ & $4,511,065,600$ \\
30 & $10,572,810$ & $6,766,598,400$ \\
40 & $14,097,080$ & $9,022,131,200$ \\
\hline
\end{tabular}

Assuming that the average daily output of a well is $4,500,000$ cubic feet in 24 hours, the theoretical life of a well drawing upon a 40 -foot sand bed under the conditions above outlined would be 2,004 days, or 5.5 years. However, variations in conditions of pressure during the life of the well change the time limit at which the sand will be exhausted. The life of the well, however, would not be much over 5 years. This calculation is based upon the open flow of the well-that is, the flow of gas into the air. A well, however, would not maintain a steady, uniform flow for a number of years, and when 
connected with a pipe line will exhaust itself much less quickly, since the total volume is seldom utilized.

Considering the problem of the life of a well from the standpoint of decrease in pressure, it is found that the above figures are largely corroborated. A decrease in static pressure of 4 pounds per month (a range of from 3 to 5.5 pounds has been observed) is about the average for the field. Some observers claim a decrease of 5 pounds per month. Few wells are considered to be of much importance after the pressure has fallen below 50 pounds. If the initial pressure is 300 pounds and the rate of decrease is 4 pounds per month, the life of the well, provided other conditions remain the same, would be 5.2 years, which corresponds closely with the time limit of 5.5 years given above. It should be remembered that the invasion of water or oil is liable to change the conditions of production at any time. If a decrease of 5 pounds per month is noted, the life of the well would be 4.1 years. The results in either case agree approximately with the experience of gas consumers in this field.

Measurements of flow of gas in pipes.-As already described on page 49 , the Pitot tube may be used in measuring the volume of gas flowing through a pipe. If the Robinson instrument is used, a hole is drilled into the pipe and threaded, and the Pitot tube is screwed in, making a tight connection. The lower end of the tube, which must be turned parallel with the axis of the pipe, should be so inserted that it may be in the neutral zone or at the point of average velocity. With the Robinson instrument the pressure due to the velocity of flow may be measured, and from this the volume of gas passing through the pipe may be computed.

The forms of instrument shown in figs. 10 and 11 may be attached to the service pipe by drilling a hole and reaming it, the connection being made tight by the pressure of the steel point when the set screws on the saddle are turned. With these instruments the static pressure and the combined static and flowage pressure are measured and the pressure due to the velocity is found by subtracting. After the measurements are made the hole in the service pipe can be closed by driving in a portion of a large wire nail which has been tapered.

It is frequently desirable to know the amount of gas which is supplied throughout the day by a service pipe. In such a case the instruments may be connected with a recording pressure gage, such as a Bristol gage, which furnishes a chart of the pressures throughout 24 hours. Two charts are usually secured-one showing the static pressure and the other the static plus the flowage pressure. By deducting the former from the latter the flowage pressure is obtained. This method of taking flowage pressure has several advantages over the use of water or mercury gages or occasional readings with spring gages, since it is mechanical, and therefore positive, and the charts can 
be studied at leisure. Pl. X shows the records taken from a service pipe during 24 hours; the irregularities in the record line correspond with the increased or decreased amount of gas used by the plant; the jogs at $5 \mathrm{a}$. $\mathrm{m}$. and $6 \mathrm{p}$. $\mathrm{m}$. correspond with the closing and opening of certain of the burners for the changing from night work to day work, and vice versa.

OBSERVATIONS ON METHODS OF DEVELOPING AND UTILIZING OIL AND GAS.

By W. R. CRane.

Methods of drilling.-Prospecting and drilling for. both oil and gas is done by the American cable tool, or oil-well, system, for which there are three different forms of drilling devices-the standard or carpenter's rig, the rig and reel, and several styles of self-contained rigs. The order in which the drilling rigs are mentioned is in accordance with their adaptability to heavy work and deep drilling. The wells in the Iola quadrangle range from 500 to 1,500 feet in depth. The formations, as a rule, are easy to drill through, being composed principally of shales, sandstones, and some limestones. The shales predominate through probably seven-eighths of the thickness of the rocks encountered. In drilling through limestone the operation is commonly called "spudding" (a term applied to drilling through hard rock), this being the most difficult part of drilling. When a well starts in limestone no conductor is employed; in other portions of the field about 20 feet of conductor is required, for which purpose an iron casing, or a tube made up of eight wooden staves, is used. The shales, especially when charged with water, are moderately soft, and the holes must be promptly cased in order to prevent caving. The casing is usually carried to within 20 or 30 feet above the cutting bit and driven as the hole is deepened. It can be readily forced through the soft shales, but where hard sandstones and limestones are encountered it is necessary to ream the hole.

The usual height of derricks in the field is from 50 to 65 feet, varying with the length of the string of tools. Even with such comparatively low derricks considerable damage is done by windstorms, which occasionally wreck them. Accordingly many operators stay the derricks with guy ropes. After the wells are completed the upper portion of the derrick is lowered to a height sufficient for handling the casing in subsequent work on the wells.

Cost and rate of drilling.-Oil and gas wells are usually drilled by contract at a charge of 80 cents to $\$ 1$ a linear foot, not including the cost of fuel and water. The speed of drilling ranges from 50 to 125 feet a day, a fair average being about 100 feet, a rate, however, which can not be attained in the harder rocks. The fuel used is either coal or natural gas. Coal is more expensive and more inconvenient to 


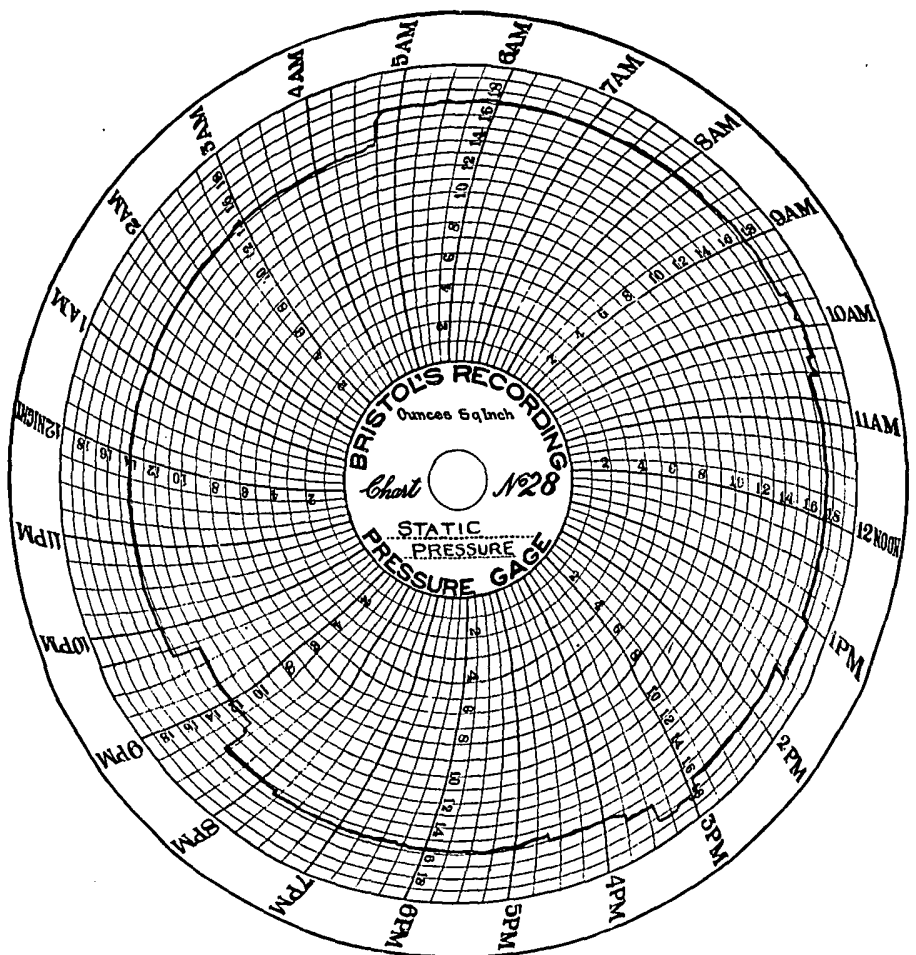

A. CHART OF STATIC PRESSURE IN SERVICE PIPE TAKEN WITH BRISTOL'S RECORDING PRESSURE GAGE.

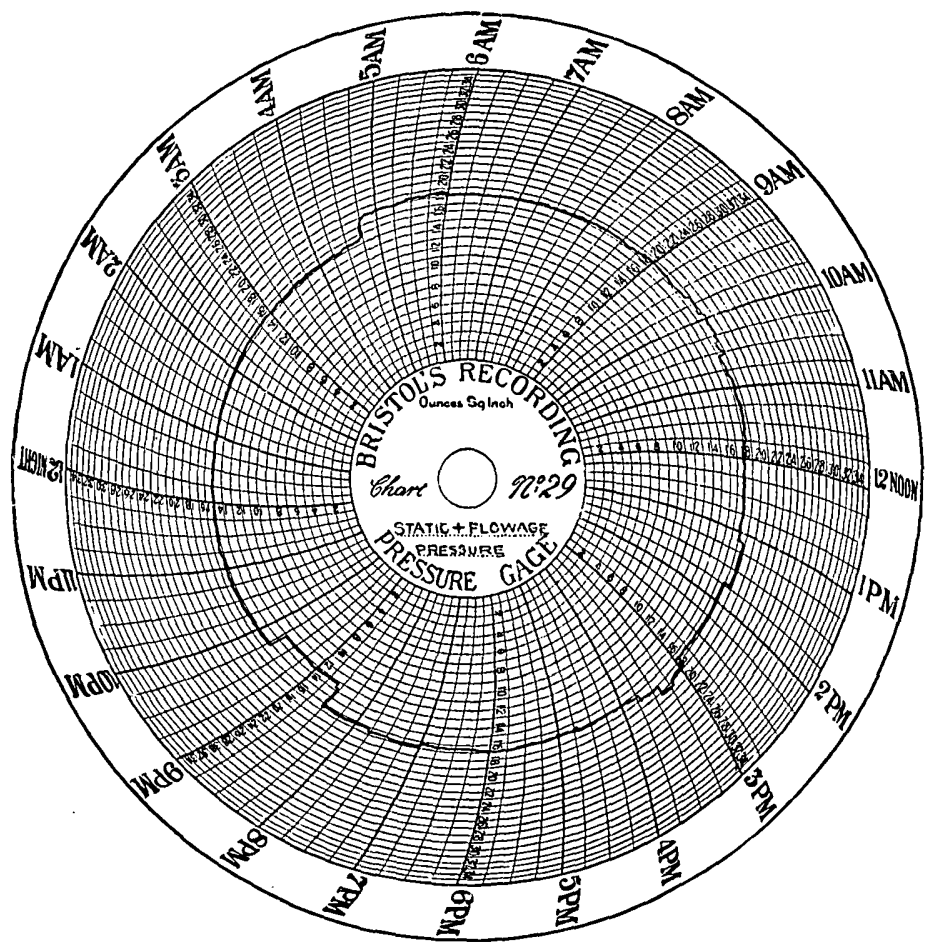

B. CHART OF STATIC FLOWAGE PRESSURE IN SERVICE PIPE TAKEN WITH BRISTOL'S RECORDING PRESSURE GAGE. 
handle, costing about. $\$ 40$ for a hole 1,200 feet in depth. Where natural gas is employed it is customary to pay $\$ 50$ per hole for the privilege of drawing a supply from the neighboring well; occasionally, however, the gas is sold at a fixed price for each foot drilled, a common charge being 5 cents per foot. The cost of a drilling rig varies according to the style used, but is somewhere about $\$ 2,500$ or $\$ 3,000$, including all tools. The labor item is by far the most expensive, ranging from 18 to 22 cents per foot. If the drilling results in a producing well the contractor finishes the well; that is, cases, tubes, and packs it, charging the owner with the actual cost of the materials used.

Systems of oil pumping.-There are several systems used in pumping oil from still or quiet wells, designated "shacklerods" and "compressed air." In the latter method air is forced into the tubing and the oil driven out through a smaller pipe. In other cases 2 -inch and 1 -inch pipes are inserted side by side, the smaller pipe making connection with the larger at a point a few inches above the end of the same; at the lower end of the larger pipe is attached a ball valve through which the oil enters, when the air entering the larger pipe from the smaller produces a suction; this constitutes what is commonly known as the geyser valve.

Shacklerods are used when wells are pumped. The power is commuricated by a device capable of producing a reciprocating movement, commonly an eccentric, and is transmitted by rods, ropes, or wires. A single power plant may operate a large number of wells. The rods, ropes, and wires which run to the pumps are guided by supports which are placed short distances apart, and are known as "bolders up," or if depressions are crossed are called "holders down." Rods are preferred on level ground, while ropes and wires are adapted to rough, uneven surfaces.

Distribution and control of gas supply. - Gas as it comes from a well is under too high pressure to.be utilized, and must have its pressure reduced. This is accomplished by so-called reducing valves, which act automatically and are controlled by the pressure of the gas. For ordinary purposes the pressure must be reduced to 4 or 8 ounces from an initial pressure of 300 pounds, more or less, necessitating reduction by stages in order to do it safely. Two regulators are usually employed, the first reducing to 60 pounds and the second from 60 pounds down to the desired number of ounces. The gas enters the automatic reducer exerting its pressure on a relatively small surface and passes out through a larger chamber. The total pressure on the opposite sides of a diaphragm being exactly balanced, is less per square inch on the larger area.

Aside from the regulation of the pressures the supply is also controlled by receivers, usually placed near the point of consumption. These, as commonly constructed, are made of several 100- to 150 -foot 
lengths of 6- or 8-inch pipe placed parallel and several feet apart, the ends being suitably connected with elbows and nipples. They constitute a portion of the main line and are provided with valves at both ends to control the flow of gas. The function of the receiver is to give a slight reserved capacity to the system by adding to the storage capacity of the main line near the point where it is drawn upon. It also serves to reduce pulsations in the flow of the gas.

It is considered one of the most difficult tasks in operating a gas line to keep it open during all seasons of the year, especially during cold weather. Formerly a crew of men were detailed to thaw out the pipes and regulators during freezing weather, but even with this precaution the pipes would frequently freeze and burst or become stopped up in whole or in part. If the wells are wet, or if even one wet well is connected with the system, serious trouble is experienced; and even with the driest wells some moisture accumulates in the pipes. The best methods for controlling supply employ drips and heaters, the former to remove the accumulated water and the latter to keep the gas at a temperature above freezing and prevent the condensation of water and the formation of ice and frost in the pipes. Drains are usually constructed of pipes ranging in length from 6 to 12 feet, with a diameter of from 6 to 8 inches. These are placed several feet below the intake pipe and are usually buried 2 or 3 feet below the surface of the ground. They are provided with caps at the ends, connection being made with the intake and discharge pipe by saddles or tees at both ends, the two pipes entering on the upper side. The gas enters with its burden of water at one end and loses it, or a large part of it, in passing to the point of discharge. Drains are usually placed at or near the points of consumption, although they are often placed along the pipe lines, in which case they are commonly called "bleeders." Heating devices are placed at intervals along the gas-pipe line and are usually situated on the low-pressure side of regulators at a distance of from 50 to 75 feet away. They are constructed by excavating a trench about 3 feet deep, 2 feet wide, and 25 feet long; walling it up and arching it over with brick. A hole is drilled into the pipe line on the lower side close to the open end of the furnace and a half-inch pipe provided with a valve screwed in and turned by means of an elbow, so as to run parallel with the main line and at a distance of from 4 to 6 inches below it. This pipe is perforated on the upper side and plugged at the rear end and is converted into a burner which can be used under the gas flowing in the main line.

Heaters are placed on the low-pressure side of regulators for the reason that gas loses much of its heat on expanding, and it is accordingly on this side of the regulators that freezing is more apt to occur. Heaters, of course, are not employed during warm weather, but drains are in constant use. 
Formerly when the static pressure was high it was the common practice to use small pipes for conveying gas considerable distances, but, nowadays, as the pressure falls off, or the gas is taken from weak wells, it is necessary to use larger pipes. Accordingly, for a line of say 8 miles, instead of the 4 -and 6 -inch pipes once in common use, pipes ranging in size from $10,8,6$, and 4 inches are now employed in different sections in the order mentioned. It is claimed by gas companies that an 8-inch pipe line presents a resistance which reduces the pressure 9 pounds a mile. While this estimate may be rather high it gives an idea of the difficulties encountered in maintaining service through supply pipes.

\section{PORTLAND CEMENT.}

The large supply of natural gas in Kansas which is available as fuel, together with the inexhaustible deposits of materials suitable for the manufacture of cement which are located in the gas field, has brought about the introduction of the Portland-cement industry in the State. The Iola Portland-Cement Company's plant at Iola (Pl. XI, $B$ ), completed in 1900, enjoys the distinction of being the first one to use natural gas for fuel. It has a capacity of 3,000 barrels per day. A second plant, which will have a capacity of 1,500 barrels per day, has been located near Iola and is now nearing completion. Three or four additional cement plants are projected for near-by portions of the State and probably some of them will be built. Because of the importance of this industry and because it promises to assume greater proportions in the Kansas field, it is thought best to give a rather full discussion of the processes of manufacture.

\section{TYPES OF SILICATE CEMENTS. $\iota$}

There are three types of cement manufactured in the United States which may be classed as silicate cements. They agree in being hydraulic, though in different degrees, and in the fact that this property is due principally to the formation of tricalcium silicate.

Puzzolan cement.-The least important class of silicate cements is puzzolan cement, produced by the mechanical mixture, without calcination, of slaked lime and silico-aluminous material, the latter being either a volcanic rock or blast-furnace slag. Of this class about 500,000 barrels were manufactured in the United States in 1903.

Natural cement. - Next in importance are the natural cements, which are produced by the calcination, at a temperature below that of clinkering, of a clayey limestone (which may or may not contain a notable percentage of magnesia) in which the quantity of lime (plus magnesia) is so low relative to the silica and alumina that little or no free lime appears in the cement. Of this kind of cement about 7,000,000 barrels

a See Eckel, Edwin C., Municipal Engineering, vol. 24, May, 1903, p. 335; also vol. 25, July, p. 1. 
were manufactured in the United States in 1903. The plant at Fort Scott, Kans., manufactures this class of cement.

Portland cement.-The most important type is Portland cement, which is produced by the calcination, at the temperature of semivitrifaction (clinkering), of a mixture of calcareous and clayey materials in the proportion of about three parts of lime carbonate to one part of silica and alumina combined. About 16,000,000 barrels of Portland cement were manufactured in the United States in 1903. The cement manufactured at Iola is of this type.

\section{CHEMICAL COMPOSITION OF PORTLAND CEMENT.}

A comparison of the results obtained by analyzing many of the best grades of cement, both domestic and foreign, warrants the limitations in composition between certain percentages, which are set forth in the annexed table, which contains data already frequently published:

Chemical composition of different Portland cemenls.

\begin{tabular}{|c|c|c|c|c|c|}
\hline & $\begin{array}{l}\text { Mini- } \\
\text { mum. }\end{array}$ & $\begin{array}{l}\text { Maxi- } \\
\text { mum. }\end{array}$ & & $\begin{array}{l}\text { Mini- } \\
\text { mum. }\end{array}$ & $\begin{array}{l}\text { Maxi- } \\
\text { mum. }\end{array}$ \\
\hline . & Per cent. & Per cent. & & Per cent. & Per cent. \\
\hline Silica, $\mathrm{SiO}_{2} \ldots \ldots$ & 19 & 26.0 & Magnesia, MgO ...... & 0 & 5.0 \\
\hline Alumina, $\mathrm{Al}_{2} \mathrm{O}_{3}$. & 4 & 10.0 & Sulphuric acid, $\mathrm{SO}_{3} \ldots$ & 0 & 2.5 \\
\hline Iron, $\mathrm{Fe}_{2} \mathrm{O}_{3} \ldots$ & 2 & 5.0 & Alkalies, $\mathrm{K}_{2} \mathrm{O}$ and $\mathrm{Na}_{2} \mathrm{O}$ & 0 & 2.8 \\
\hline Lime, $\mathrm{CạO}$.... . . & 58 & 67.0 & & & \\
\hline
\end{tabular}

As has already been stated, silicate cements owe their properties principally to the formation of a tricalcium-silicate molecule, $3 \mathrm{CaO}$, $\mathrm{SiO}_{2}$. This was first suggested by Le Chatelier. ${ }^{a}$ The tricalciumsilicate molecule is accompanied by varying amounts of similar molecules containing calcium and aluminum, and calcium and iron, the exact formulæ of which are not as yet so well understood. Le Chatelier ${ }^{b}$ gives them as $3 \mathrm{CaO}, \mathrm{Al}_{2} \mathrm{O}_{3}$, and $3 \mathrm{CaO} . \mathrm{Fe}_{2} \mathrm{O}_{3}$, while Newberry ${ }^{c}$ holds they should be $2 \mathrm{CaO}, \mathrm{Al}_{2} \mathrm{O}_{3}$, and $2 \mathrm{CaO} . \mathrm{Fe}_{2} \mathrm{O}_{3}$.

According to Newberry's formula, the ratio between lime and silica is about 2.8 to 1 ; between lime and alumina, about 1.1 to 1 , and between lime and iron oxide, about 0.7 to 1 . It is evident, therefore, that the per cent of lime required will vary with the amount of alumina and iron present. Should a cement be composed entirely of the limesilica molecule it should have about 73.7 per cent of lime and 26.3 per cent of silica to correspond with the above formula; should it be composed entirely of the lime-alumina molecule it would have but a little over 52 per cent of lime; and if composed entirely of the lime-iron molecule it would contain only 41 per cent of lime. It is

\footnotetext{
¿Annales des Mines, 1887, p. 418.

b Op. cit., p. 418.

c Jour. Chem. Ind., 1897, p. 889.
} 
evident, therefore, that the higher the proportion of iron and alumina the lower will be the proportion of lime and silica.

At present it is a little uncertain just what effect the alumina and iron have on the cement. Evidently they lower the fusion point of the clinker, and therefore reduce the cost of burning, particularly of the iron, and a proper amount of them is therefore desirable. The pure lime-alumina cement, made in laboratories, sets very quickly, indicating that the alumina tends to reduce the time of setting. A pui'e lime-iron cement, made by Doctor Schoch, would not set under cold water but did so readily under hot water, making a pat of constant volume and great strength. It is generally believed that the combined alumina and iron oxide should not exceed one-half the amount of silica. A desirable shale, therefore, is one which has some alumina and iron oxide in it to render the clinker more easily fusible, and at the same time not enough to make the cement too quick setting nor to reduce the proportion of the tricalcium-silicate molecule too greatly.

Certain objectionable elements, such as magnesia and sulphur, which may exist as impurities in the limestone, shale, or fuel are to be avoided. It is generally believed that magnesia is objectionable when present in quantities greater than 3 to 5 per cent. Years ago engineers generally held that not exceeding 2 per cent of magnesia should be present; later they raised this to 3 or 4 per cent, and now many of them admit that 5 per cent is allowable. Similarly, the amount of sulphur should not be very great-just how great is variously stated by different engineers.

It is probable that the particular condition in which the sulphur exists is an important consideration. In the form of calcium sulphate it is less objectionable than when in the form of calcium sulphide, as in the latter case the sulphur readily unites with the iron present and later is oxidized to iron sulphate, which first swells up and cracks the cement and later dissolves out, each process tending to destroy the cement. In the table quoted above the sulphur trioxide is limited to 2.5 per cent, yet when plaster or gypsum is added to retard the setting this amount may be considerably exceeded, since the sulphuric acid thus added, being already in combination with lime, can not exert any considerable chemical influence on the cement itself. During the last two years the price of good coal has been so high that many cement manufacturers have, it is reported, resorted to the use of cheaper coal, using some carrying so much sulphur that they would have rejected it previously. In this way, it is said, cement with the sulphur content considerably beyond the danger line as previously fixed has been forced on the market, without any bad.results following.

By way of summary, then, it may be stated that a good Portland cement can be made from a limestone carrying from 75 to 100 per cent

Bull. $238-04-5$ 
of calcium carbonate, by mixing it in proper proportions with clay or - clay shales, provided the impurities present in the limestone are principally silica, alumina, and iron, and provided, further, that neither the limestone nor the shale has sufficient magnesia or sulphur to exceed the limits above stated. A limestone having from 85 to 90 per cent of calcium carbonate may be, therefore, just as desirable as one theoretically pure. The clay and clay shales may have a high proportion of lime present, as many of the Kansas shales do, and still be very desirable, for the lime in the shale will serve the same purpose as lime in the limestone. The main features to guard against are too large an amount of magnesia or sulphur, and an amount of alumina and iron oxide combined not equal to one-half the amount of the silica.

Physical properties. - Careful chemical tests are made at each step during the process of the manufacture of cement. Similarly, the finished product is subjected to careful tests, records of which are retained, showing the character of the cement going out in each shipment. All the physical properties which are desirable in cement are summarized below:

Gravity, 3.15 to 3.25 .

Time of setting: Quick setting; initial set, 15 to 25 minutes; final set, not over 2 hours. Ordinary setting; initial set, 45 to 60 minutes; final set, not over 8 or 10 hours.

Fineness: 100-mesh sieve, not more than 10 per cent residue; 200-mesh sieve, not more than 25 per cent residue.

Tensile strength: Neat: 24 hours, 250 pounds per square inch; 7 days, 450 to 500 pounds; 28 days, 550 to 800 pounds. Three parts sand mortar and one part cement: 7 days, 175 to 200 pounds; 28 days, 225 to 400 pounds.

Suundness: Should not check nor crack when tested in cold or hot water or steam, but should maintain a constant volume throughout.

\section{RAW MATERIALS USED IN THE MANUFACTURE OF PORTLAND CEMENT.}

Siliceous and pure limestones. - About 67 per cent of the Portland cement manufactured in the United States in 1903 was made from a mixture of argillaceous limestone and pure limestone, the principal material being argillaceous limestone which appioximates the ideal Portland-cement material, the pure limestone used being added to ottain the proper composition.

Marl and clay.-Calcareous marls obtained from lake basins are extensively used. Inasmuch as they are usually quite pure lime carbonates, they require the addition of clay to bring them up to the proper composition for Portland cement. About 12 per cent of the cement produced in 1903 was of this kind.

Chalky limestone and clay.-Chalky limestones vary from rather pure calcium carbonate, low in both magnesium and clayey materials, to an impure clayey limestone requiring little additional clay to make 
it fit for use in the manufacture of Portland cement. About 5 per cent of the cement produced in the United States in 1903 was manufactured from such material.

Caustic-soda waste and clay.-Precipitated lime carbonate, which is a by-product in the manufacture of alkali, may be combined with clay material for Portland cement. However, there is not much of it used. Slag and limestone. - Slag running high in lime, which is a byproduct of blast furnaces, may be mixed with pure limestone and burned to form Portland cement, but cement of this class amounts to but a very small per cent of the annual production.

Pure (hard) limestone and clay or shale.-These materials are the ones used in the manufacture of cement at Iola. The limestoné, being relatively pure, requires the addition of a considerable amount of clayey material in order to produce the desired combination. About 13 per cent of the Portland cement manufactured in the United States is from such material.

\section{CEMENT MATERIALS IN THE IOLA QUADRANGLE.}

There is practically no limit to the amount of Portland cement that might be manufactured from limestones and shales located within the Iola quadrangle. There are several localities at which materials of suitable chemical composition and physical properties may be obtained, and the location of the cement plants thus far has been chiefly determined by the availability of gas, water, and railway facilities. The limestone used is from the Iola formation, which occurs in a heavy bed and is quite uniform in character, and the shale is from the Concreto formation which overlies the limestone. The relation of these two formations is particularly fortunate, and the fact that the shales occur in hills rising above the limestone bas made possible the location of the plants conveniently near both materials.

The geologic map accompanying this report (Pl. I) shows the limits and extent of the limestone and the shale formations. Not all of them are suitable for the manufacture of cement, and in some cases it is impossible to find both shale and limestone at the same locality. The Iola quadrangle, however, may be considered as capable of supplying all the material which the industry may demand, and bids fair to become the center of the cement industry in the State.

\section{CEMENT PLANTS AND PROCESSES OF MANUFACTURE.}

The plant of the lola Portland Cement Company, situated just south of the limits of lola, was the only one in operation in 1903 . The Kansas Portland Cement Company, located about a mile northeast of Gas, a station 2 miles east of lola, will begin manufacturing early in 1904 . The two plants are similarly situated. They are located at 
the base of hills from which the shale is obtained, the limestone being quarried at a slightly lower level near by.

Iola Portland-cement plaint. - The first process in the manufacture of cement is the quarrying of the material. At the Iola plant the shale is dug from the side of a mound and the pit accordingly requires no artificial drainage, while the limestone which is used-lies below the level of the ground and must have its pit pump (Pl. XI, $A$ ). The limestone is quarried by means of heavy blasting, which breaks it into large pieces, some of which require additional breaking in order to reduce them to a size that permits. easy handling. Both shale and limestone are transported to the mills by means of a steam tram.

The next process is the crushing of the material. The limestone is put through a Gates crusher and the shale through a Williams mill. The material is then dried so that it will not clog in the subsequent process of pulverizing. It is then finely ground in Griffin mills, after which water is added to it, and it is agitated in pug mills.

Water is used in mixing the materials, the method being known as the wet slurry process. The shale and limestone are stirred together in a large tank from which the mixture is conveyed by means of pipes. It is essential at this stage that the slurry should be of the proper composition. An attempt has already been made to govern this in a rough way by using definite amounts, by weight, of the shale and the limestone, and when the material has reached the slurry tanks chemical analyses are made and the additional amounts of limestone or shale, which the mixture may require, are added before it goes to the furnaces. At this plant 21 rotary furnaces are installed, yielding 3,500 barrels per day of 24 hours. They are made of heavy boiler steel in the form of a tapering cylinder, about 60 feet in length and 8 feet in diameter at the larger end. They are lined with tire brick, which reduces the internal diameter to about 6 feet at the front end and to between 4 and 5 feet at the rear or smokestack end. They are mounted on trunnion and $\operatorname{cog}$ gearings which give them about 2 revolutions per minute. The slurry is automatically fed into the smaller or upper end of the kiln and the gas into the opposite end; the blaze travels through the kiln, producing the greatest heat near the burner. The inclination of the kiln causes the slurry, which is prevented from coking by the rotation of the kiln, to travel toward the lower end, thus becoming heated gradually. As it passes the hottest place in the furnace it is fused into what is known as clinkers, in the form of little balls from one-half to one inch in dianeter, which roll out at the lower end of the kiln into a conveyor. After the clinker has cooled it is pulverized by Griffin mills and conveyed to storerooms, where it is held for shipment. Before grinding, however, a minor amount of crude gypsum is added in order to retard the set. The sulphur trioxide 


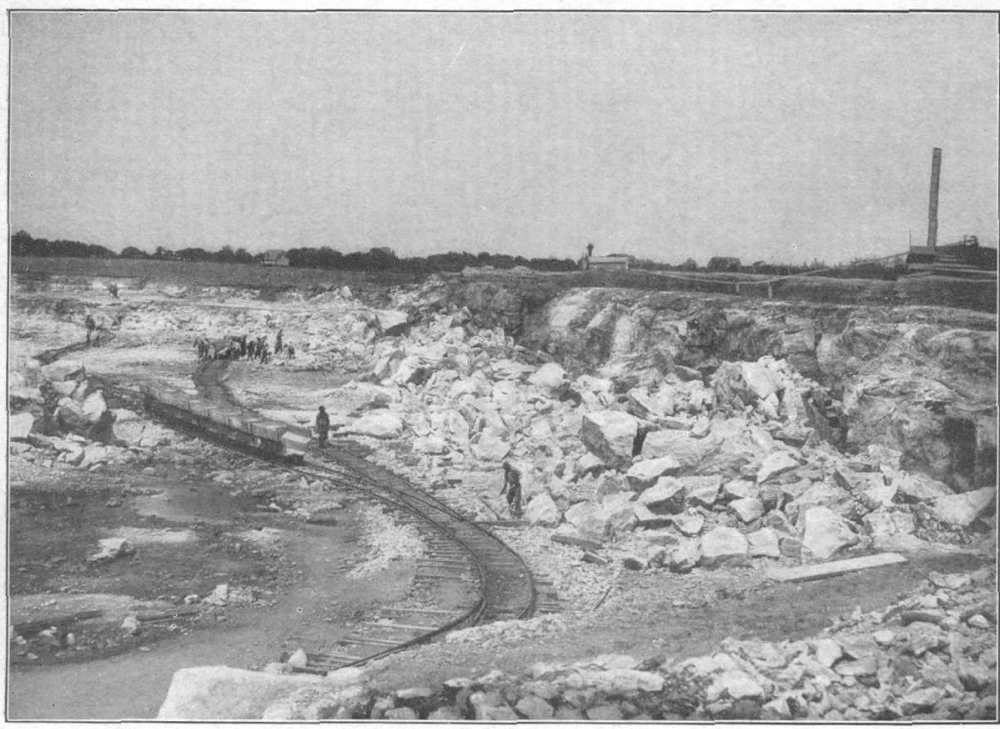

A. LIMESTONE QUARRY AT THE IOLA PORTLAND CEMENT COMPANY'S PLANT,

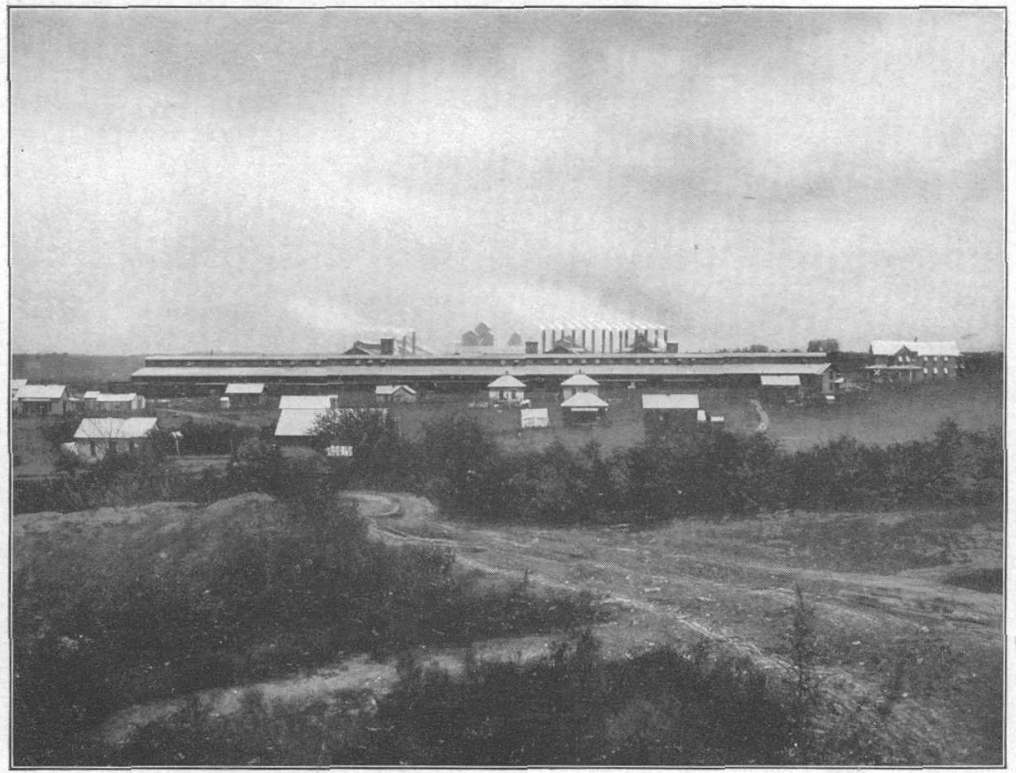

B. IOLA PORTLAND CEMENT COMPANY'S PLANT. 
of the gypsum combines with the lime alumina of the cement, which would otherwise be quick setting.

K'ansas Portland-cement plant.-This plant, which will begin operations early in 1904, is similar in a general way to the one just described; the materials used are the same and will be obtained by the same methods. The limestone will be ground by an Austin No. 8 gyratory crusher, which will receive the rock directly from the quarry. It will then be passed through a revolving screen which will take out about two-thirds of the material and send the remainder to a No. 5 crusher. The shale will be treated first with a Williams pulverizer and the raw material finally pulverized by Griftin mills set in wooden frames. The plant will have 8 rotary kilns, giving a capacity of 1,500 barrels per day of 24 hours.

\section{BRICKMAKING.}

\section{CHARACTERISTICS AND PROPERTIES OF CLAYS.}

Definition and composition of clays.-Clay may be defined from a physical standpoint as a variable mixture of fine-grained mineral fragments possessing, when wet, the property of plasticity which permits it to be molded into any desirable shape, and, when subsequently $d r y$, to retain that form. The mineralogical constituents of a clay are hydrated aluminous silicates, free silica, iron oxide, carbonate of lime, and fragments of various silicate minerals in more or less decomposed condition that have survived the destructive agencies to which they have been" subjected. When examined chemically the components, in addition to chemically combined water, are found to be silica, alumina, iron oxide, lime, magnesia, potash, and soda, together with small amounts of titanic acid, sulphuric acid, manganese oxide, pbosphoric acid, and organic matter. The hydrated silicate of alumina known as kaolinite is commonly spoken of as the clay base; it is derived from the decomposition of feldspars. The additional substances in clays are due to the varying amounts of other mineral matter which was present in the original rocks or which has subsequently become mixed with the kaolinite.

When a clay is heated above a certain temperature it forms a hardened rock-like mass which if reground no longer shows plasticity. In the process of burning certain substances in the clay assume a glassy form. Commonly, in burning clays, three stages are recognized, namely, incipient fusion, fusion, and viscosity, according to the degree of completeness of the fusion. The substances which fuse readily are spoken of as.fluxing materials, and the more refractory are spoken of as nonfluxing. However, if the temperature be sufficiently high all the elements in the clay will fuse.

Classification of clays as to origin.-Clays may be classified as residual and transported clays. Residual clays are formed by the dis- 
integration of rocks in place. The original sources of all clay material are igneous rocks, the decomposition of their mineral elements, especially the feldspars, giving rise to a surface layer of clay. Similarly, stratified rocks upon weathering produce clays, the percentage of clay varying according to the nature of the rocks. Examples of clays originating in this way are the disintegrated surfaces of shale beds and the clays which result from the solution of limestones. Such clays approach very closely to the condition of soils.

Transported clays are those that result from various mechanical agencies which have removed disintegrated rock materials from the place of origin. Silts which have been transported by running water, glacial drift which has been produced by the action of ice, loess which consists largely of wind-blown material, and shales which are derived from clay deposited in lakes and oceans, are all transported clays.

It is possible that certain clays have resulted from precipitation and are accordingly of chemical origin.

Classification of clays as to uses.-Aside from the uses to which clays are adapted, either without artificial preparation or by the admixture of additional materials, they are the source of a large number of manufactured products. These may he classed as (1) paving brick; (2) common brick, front brick, washed brick, terra cotta, roofing tiles, decorative tiles, terra-cotta lumber, and enameled brick, used in building and decorative art; (3) hollow ware, including drain tiles and tile pipes, used for engineering and hygienic purposes; (4) refractory products, including fire brick, glass pots, and gas retorts, used in manufacturing and engineering industries; (5) pottery and porcelain, including washing clays and slip clays, used for domestic and decorative purposes.

\section{CLAYS IN THE IOLA QUADRANGLE.}

The formations of the Iola quadrangle are all stratified. The residual clays derived from them are rather unimportant. Formerly they were used to a limited extent in the manufacture of common brick, the material utilized being more or less mixed with organic matter and therefore largely in the nature of a soil. Deposits of this nature are usually thin and variable.

There are a number of important shale beds within the area which, upon being ground, furnish a clay suitable for the manufacture of paving brick, common brick, hollow ware, and common pottery. Thus far the only use made of them is in the manufacture of common brick for buildings and sidewalks. The shales used, although coming from different geologic formations, are similar in all instances. The bricks are burned with natural gas, and the cheapness of this fuel has stimulated the development of this branch of manufacture. Thus far no plant has been erected for the manufacture of vitrified or paving orick, this being due partly to the fact that the demand has been 
principally for common brick, and partly because the paving brick needed has been supplied from plants outside of the quadrangle. The construction of down-draft kilns would probably permit the burning of vitrified brick; some experiments have already been undertaken along this line. In adjacent portions of the State some hollow ware and pottery are manufactured from the same class of shales that are found within the Iola quadrangle.

\section{CONDITION OF THE BRICK INDUSTRY.}

Brickmaking is an important industry in the vicinity of Chanute, Humboldt, Iola, and Laharpe. The great bulk of the product is sold at home, the demand for building brick having been very large on account of the growth of towns where industries using oil and gas have been established. The capacities of the plants have outstripped the local demand and bricks have been shipped as far south as Galveston, as far west as Albuquerque, and north and east far beyond the limits of the State. For three or four years conservative business men have been arguing that the demand for brick was unnatural and that the rapid establishment of plants would soon result in so great a production that the prices would be lowered almost to the point of cost, but such predictions have not yet been verified, the market for the season of 1903 being better than at any other time since brickmaking was begun in the gas belt. What the further development will be is a mere guess, but it seems probable that there will be no material decrease in the near future. During 1903 approximately 65,000,000 brick were manufactured at the plants described below, with a value, at the factories, of about $\$ 325,000$.

Brick plants at Chanute.-Two brick plants are located at Chanute, one about $2 \frac{1}{2}$ miles south of town, within the Iola quadrangle, the other about 3 miles southwest of the town, one-half mile, outside the quadrangle. The plant south of the town belongs to the Coffeeville Vitrified Brick and Tile Company. It has 7 kilns, with a capacity of 300,000 brick each and an aggregate capacity of from 60,000 to 75,000 brick each 24 hours. The kilns are of the ordinary kind, open at the top; except when temporarily closed with each charge. Gas is admitted on each side at the base. The kilns are stationed side by side about 20 feet apart. A. large supply pipe rests on top of the ground midway of the alley between each two adjacent. kilns, with 18 side lines, laid about 3 feet apart, leading to each, giving 36 burners to each kiln. A mixer with a 3 -inch cross section is placed on each side pipe just outside the kiln. The temperature of the kiln is controlled largely by the amount of air admitted. Instead of regulating the amount of gas entering the kiln it seems to be more convenient simply to regulate the amount of air, which is easily done by adjusting the collar on the mixer so as to make larger or smaller air openings and in this way control the amount of actual combustion. 
Steam power is used throughout the plant, the steam being generated in boilers by burning gas. Two boilers, with an aggregate capacity of 180 horsepower, furnish the necessary steam, which is used in one engine with a capacity of 128 estimated horsepower.

The shale is first pulverized by passing through an ordinary dry-pan pulverizer. From here it goes to the pug mill, where it is tempered by a stream of water properly controlled, and passes on to the auger and out onto the belt conveyer, as customary in modern brick plants. A rotary cutter, with 22 wires, with a maximum capacity of 125 brick per minute, cuts the clay into brick, which are then carted away to a gas-heated drying room, whence they are built directly into the kilns.

The mine, or shale pit; is a few rods north of the mill and is sunk downward from the surface, the shale being drawn up the incline in cars operated by a cable from the mill. As the pit now appears its walls present a vertical section of about 60 feet. A sandstone at the top is 12 feet thick at the north side of the pit, but decreases southward, owing to surface variations, to a thin edge, where mining first began. Shale underlies the sandstone, continuing to the bottom of the pit and probably much deeper. About 5 feet below the bottom of the sandstone is an 18-inch bed of limestone, as seen at the south end of the pit, which gradually decreases northward and entirely disappears 75 or 100 feet before the north end of the pit is reached. Below the limestone the shale is uniform in character, fine-grained, dark gray in color, and practically free from sand.

In operating the mine the material is first loosened or broken down by blasting. An ordinary power churn drill is operated in the sandstone, which is first blasted off and carried away, so that the breast of sandstone precedes the breast of shale by a few feet. All the loose sand and the smaller fragments produced by the shot are mixed in with the shale, and help to prevent shrinkage while firing the brick. The shale is drilled by hand drills of the auger type, two men drilling a hole 5 feet deep in from 30 to 45 minutes.

The plant south west of Chanute, owned by the Kansas Vitrified Brick Company, and lying outside the limits of the Iola quadrangle, obtains its shale from the Concreto bed, which overlies the Iola limestone. The company manufacture the same kind of brick as those already described, its plant is similar, and its shale obtained from a pit level with the surface of the ground. There is not enough difference in the general properties of the two shales to enable one to distinguish between them by examining hand samples. A description of one plant is, therefore, practically the same as a description of the other.

Brick plant at Humboldt. -One brick plant is located about $1 \frac{1}{4}$ miles north of Humboldt and is owned by the Humboldt Brick Manufacturing Company. It began operations in the spring of 1898 and has 
a capacity of 40,000 brick a day. Its machinery consists of the regulation dry pan for crushing the shale and a pug mill and auger for molding the brick. This company is making a specialty of sidewalk brick, which they re-press, producing a variety of patterns on the top side of the brick.

The plant is operated throughout by gas for fuel. Steam power, generated by burning gas, is used, and the kilns are fired by gas, being arranged practically the same as those of the Chanute plant. The shale used lies on the surface adjacent to the plant and is obtained by sinking a pit, the material being serviceable almost from the surface of the ground. As these shales lie almost on top of the Iola limestone they belong to the Concreto horizon, the same used by the Kansas Vitrified Brick Company for its plant southwest of Chanute. The quality of the shale here is practically the same as at Chanute, and the quality of the brick likewise, whatever differences may be observed being due principally to slight differences in manufacturing processes.

Brick plants at Iola.-There are 4 brick plants at Iola, 2 owned by the Iola Brick Company, 1 by the Star Brick Company, and 1 by the Home Brick Company.

The Iola Brick Company's plant No. 1, with a capacity of 35,000 brick a day, is situated about a mile east of the town. It was installed in 1896, and manufactures principally common, or building, brick and sidewalk brick. Plant No. 2, installed in 1899, is located south of the town, on the north side of the mound which supplies shale to the Iola Portland-Cement Company's plant.

Its plant No. 1 (Pl. VIII, $A$ ) is the oldest plant at Iola, and was one of the first to employ gas for burning brick. It employs the up-draft or open-top kiln, with the tops temporarily closed for each charge. Gas is admitted to the side of the kiln as described for the Chanute plant. The shale is obtained near the plant by digging or mining; the soil covering is thin and the shale lies immediately below. The pit is operated to a depth of about 20 feet and is developed laterally as requirements demand. As the shale lies immediately on top of the Iola limestone it belongs to the Concreto series.

Plant No: 2 was established at the foot of a little mound south of town, because experience showed that shale could be mined more cheaply from a hillside, where no expense was necessary for draining the shale pit and where gravity could be used in transporting the shale from the pit to the plant, than on a level where the pit was worked downward and must be drained by pumping. The plant has a capacity of about 40,000 brick a day. Its general equipment, the kind of brick made, and methods of operations are in no essential way different from those at plant No. 1. 
In 1899 the Star Brick Company established a plant at Iola, which has a capacity of 40,000 brick a day; and is located on the northeast corner of the mound which supplies the Iola Portland Cement Company with shale. It produces common building brick and sidewalk brick. The shale used is the same as that used by the Iola Brick Company in their plant No. 2.

The Home Brick Company's plant, located about $1 \frac{1}{2}$ miles east of Iola, began operations in June, 1902. The plant was built expressly to manufacture a high grade of pressed brick for fine buildings and has started out very successfully, supplying the brick for the new courthouse now in process of erection at Iola and already receiving a satisfactory patronage from outside sources; it also makes common building brick. Its total capacity is 30,000 brick for a 10 -hours' run. It uses shale immediately at its plant, there being about 30 feet of the Concreto series there. It has its own gas wells near the plant and will drill more when the ones now in use are exhausted.

Brick plants at Lalarpe. - Laharpe had one brick plant in operation and two others in process of construction during the summer of 1903. The plant in operation was installed in 1900 with a capacity of from 20,000 to 25,000 brick a day. Gas is the only fuel used, the motive power being steam generated by gas. The kilns are supplied with gas drawn through mains and fed into the kilns as at Chanute. The kilns used are of the ordinary up-draft variety. This plant makes common, or building, brick and sidewalk brick only. It obtains its shale by mining the Chanute shales from underneath the Iola limestone, having run an incline through about 35 feet of limestone; the shale is now being worked to a depth of 25 to 30 feet below the bottom of the limestone. In obtaining the shale by this method, it is necessary to mine it out so as to leave large pillars standing to support the roof. A room-and-pillar system like that in coal mining is employed. The entries and rooms, however, are very wide, as the overlying limestone is heavy and unusually free from vertical seams.

COAL, IEAD, AND ZINC.

COAL.

There are no workable beds of coal outcropping in the Iola quadrangle. Some beds have been found, but their thickness does not exceed 6 inches. In the Dudley shale on the northwest side of the limestone ridge, which terminates 3 miles nortbwest of Walnut, a thin coal bed was discovered in digging a well. On Coal Creek, 2 miles east of Humboldt, a bed of coal about 6 inches thick occurs in the Chanute shale. At a place where it was under very thin cover a small amount was obtained by stripping. The outcrop of this bed, or possibly of other beds which occupy the same horizon, has been noted at 
several places along Coal Creek, and small pieces are occasionally washed out of the shales during high water.

Some prospect wells have been sunk for coal, and others which have been bored in search of oil and gas show the occurrence of coal beds at a considerable depth, most of them in the Cherokee shale. No very reliable data in regard to their thickness are available, since they have usually been encountered in drilling with a churn drill. The record of a well sunk at St. Paul with a diamond drill shows several beds, the thickest of which is 2 feet; this was found at a depth of 184 feet, occupying a position immediately below the Pawnee limestone. In the Cherokee shale six beds of coal were reported, varying in thickness from 6 inches to $1 \frac{1}{2}$ feet. The Acers well at Iola, commonly known as the old mineral well, was drilled with a diamond drill in search of coal, but no information as to the coal beds encountered is available. Evidently none were found which were considered thick enough to work.

LEAD AND ZINC.

In digging wells which pass into or: through the limestone formations, small amounts of lead and of zinc have occasionally been found. An occurrence of this character was observed in a well in the Shaw limestone just south of Savonburg. The lead and zinc, although conspicuous in the débris thrown out from the well, were not considerable in amount. Such occurrences of lead and zinc are very common in limestone formations, and may be considered sporadic and not indicating deposits of economic importance.

\section{WATER SUPPLY.}

In the Iola quadrangle the portion of the rainfall that is carried away by streams finds its way to the Mississippi either around the northern border of the Ozark region by way of the Missouri or to the south round the southern border by way of the Arkansas. The watershed between these two drainages is a low narrow divide, which extends from the foot of the Rocky Mountains near Denver, Colo., into southeast Missouri. It enters the Iola quadrangle west of Bayard and passes by the way of Moran to Elsmore and thence in a southeasterly direction. The streams which head to the east of the divide form the headwaters of the Little Osage and its tributary, the Marmaton. Practically all the remaining streams flow into Neosho River within the borders of the quadrangle.

Streams.--All of the streams here under discussion carry potable water. Neosho River is the largest. It enters the quadrangle at the northwest corner and flows nearly south along the west border of the area to Chanute, from which point it fluws southeast, passing out of the quadrangle at about the middle of the south side. Its source is about 125 miles to the northwest in Morris County. As its hydro- 
graphic basin has an area of approximately 3,670 square miles and has an annual precipitation of 35 to 40 inches, it carries a large amount of water and consequently is a stream of great economic importance. Its average flow, as estimated by Mr. F. H. Newell, ${ }^{a}$ based upon measurements made by W. G. Russell at Iola during 1902, is 2,492,041 acre-feet per annum. The flood plain averages about 2 miles in width, although in some places where heavy limestones are cut through its width is less than a mile. The stream meanders through the flood plain, producing many short oxbow curves and broad windings. In times of high water it overflows its banks and inundates almost all of the flood plain area, causing great destruction of crops and domestic animals and sometimes of human life. Along portions of the river dikes have been constructed to protect the bottom lands from overflow.

In the part of its course which lies in the Iola quadrangle, the Neosho has reached a graded condition and consequently there are no falls or cataracts along it and few and unimportant riffles or shoals. It is very serviceable as a supply of water for domestic uses. Iola and Chanute have city water plants which draw their supply from it and Humboldt contemplates the early installation of a similar plant.

A number of small streams enter the Neosho from the west, the largest of which are Owl Creek near Humboldt, Village and-Turkey creeks near Chanute, and Elk Creek opposite Shaw. From the east it receives Elm Creek at Iola, Coal Creek at Humboldt, Big and Canville creeks near Shaw, Fourmile Creek near Erie, and Rock Creek near St. Paul.

The streams in the northeast part of the Iola quadrangle rise near: the escarpment formed by the Bronson limestone. This section is more deeply dissected than the remaining portion of the quadrangle, the valley of the Marmaton, where it leaves the quadrangle, being 200 feet below the upland.

The only stream in the area under discussion large enough to furnish water power is the Neosho. A dam built across it at Iola has furnished power for a flouring mill and a sawmill, At Humboldt a dam has also been employed for running a flour mill and some small factories. Since the discovery of natural gas the use of this water power has been neglected to a great extent and there is little indication that it will ever be restored so long as the gas is abundant. The possibilities of water power along the Neosho are, however, worthy of notice. The stream has a fall of over 100 feet within the quadrangle, which amounts to about 3 feet per mile. At many places there are sites favorable for the construction of dams which might give a fall of from 12 to 15 feet. It is possible that some day the power which may be developed in this way will be used.

a Newell, F. H., Report of progress in stream measurements for the calendar year 1902; Water-Sup. and Irr. Paper, U. S. Geol. Survey, No. 84, 1903, p. 116. 
Springs.-There are practically no prominent springs in the country under discussion. In many places, however, the seepage of water on hillsides and along the minor drainage courses where there is a considerable mantle of detrital material and soil makes possible what are called springs, although they are in reality of the nature of wells. Occasionally seeps are found which, during wet weather, furnish a small flow which is usually utilized as stock water. Nowhere are springs depended upon for domestic use, though the water supply is often denominated a spring by the inhabitants.

Wells.-Shallow wells formerly supplied water for domestic use. They were spring wells of the nature above described. Now that the country is practically all settled and it has become necessary to obtain water on the uplands where there are no small drainages, many deep wells have been dug or drilled. Good potable water is not readily found, since nearly everywhere the shales encountered in drilling contain soluble mineral matter which gives the water a brackish taste. Many wells are supplied by ground water which finds its way along the joints and bedding planes of the limestones, in which case it is of the quality spoken of as hard. In certain areas, however, the formations carry beds of sandstone (particularly in the belt of country occupied by the Chanute shale), from which water that is soft may sometimes be obtained. A few years since, efforts to obtain water which would not fail during unusually dry seasons led to the drilling of deep wells and developed the fact that where the sandstones in the Chanute shales can be reached at a moderate depth, a supply of good water is often available. By reference to the map it will be seen that this belt of country extends in a diagonal line through the quadrangle to the west of the line of outcrop of the formation. In the vicinity of Moran and Bronson the importance of this water-bearing horizon has been quite fully determined. In prospecting for water farther west these sandstones lie at a greater depth and the water found in them is usually more or less salty. An explanation of this may he found by studying the dip of the formations in the field in general; the rocks dip west and are known to extend for a long distance in that direction without a change of dip, their only outcrop being that in which they take in the water. Accordingly they become saturated, and having no outlet, the soluble salts in the rocks tend to become concentrated into a brine. The deep wells drilled in prospecting for oil and gas have shown that salt water is practically everywhere present in the rocks which lie at a considerable depth. . The portions of the formations near the outcrop may be said to have been leached of their soluble salts, and accordingly it is only in these places that the water is fresh. 


\section{SOILS.}

Origin of soils. - Soil is a mixture of fine-grained materials which have resulted from the disintegration and decomposition of rocks and which are mingled with a varying amount of organic material and with chemical substances derived from solution. The fragmental materials are derived from igneous or sedimentary rocks and may be redeposited and eventually form other sedimentary rocks. In the. complete cycle soil represents a transitory stage. In the redeposition of rock materials, mechanical sorting gives rise to beds which are arenaceous (sandstones) or argillaceous (shales), according as the material that predominates is sandy or clayey. Rock materials which go into solution, such as salts of lime and magnesia, may be deposited in the soils by evaporation or precipitation, or, if these processes take place from bodies of water, may form sedimentary beds (limestones, dolomites, gypsum, etc.).

The principal classes of sedimentary rocks are (1) limestones and dolomites, (2) shales, and (3) sandstones. They, however, grade into each other, so that limestones are more or less shaly and sandy, shales are more or less limy and sandy, and sandstones are more or less shaly and limy. Limestones and dolomites, upon weathering, are largely carried away in solution. The argillaceous matter which they contain goes to form a clay soil, while the small fragments and the coarser pieces which result from weathering, as well as the included flints, form sands and gravels. Sandstones upon disintegration become sands and produce sandy soils, while shales give rise to clay scils.

Classification of soils. - In accordance with the foregoing discussion soils may be classified according to texture as gravelly, sandy, silty, and clayey. These classes may be recognized without mechanical analysis. -Inasmuch as soil particles are, however, never of uniform size, soils may be more appropriately described by combining the textural terms; for example, we may speak of sandy clays, silty clays, sandy. silts, etc.

According to their place of origin, soils may be classed as (1) sedentary, (2) migratory, and (3) transported. Sedentary soils are those which are derived by disintegration and decomposition of rocks in place, the materials which are removed in the formation of the soil being carried away in solution. Migratory soils are those which are shifting from their place of origin and are moving with the slope of the surface, largely as a result of gravitative action. The area occupied by them is usually connected with their place of origin. Transported soils consist of materials which have been moved by the action of water, icc, or wind. They may accordingly be considered under the subclasses of alluvial, glacial, and eolian soils:

Soils of the Iola quadrangle.-The area here under discussion has not been subjected to glacial action and there are no important accumulations of wind-blown materials. Along Neosho River and some 
of the larger creeks, however, there are transported soils which are alluvial. Neosho River, which is the only important stream entering the area, traverses in its upper course a belt of country occupied by sedinuentary rocks. The materials which it transports are accordingly sands, clays, and gravels derived. from limestones, sandstones, and shale beds. Except for the assorting of these materials and the commingling with them of a larger amount of organic matter the alluvial deposits do not differ from those found along the creeks that lie witbin the Iola quadrangle. The alluvium along Neosho River is seldom more than 2 miles wide, and in places its area is so constricted as a result of the rock walls which limit its flood plain that it is little more than a mile in width. Within the alluvium are occasional beds of gravel and sand, but its surface is principally covered with fine silts. Along Rock, Canville, Big, and Elm creeks, as well as on certain smaller streams, are narrow areas in which flood-plain deposits are formed, the material being derived from the drainage basins of the streams.

On the uplands the soils are in part residual and in part migratory. The rocks, as will be seen by reference to the geologic map, are shales and sandstones alternating with limestones. The topography is of the indistinct terrace and escarpment type. The soils lying on the terraces have resulted largely from the disintegration of rocks in place, while at the base of the escarpments and on the more decided slopes the soils are migratory.

It is not possible to show in this discussion the types of soils which would be distinguished in a soil survey. However, the limestones, sandstones, and shales have each contributed to the soils, and accordingly we find clays, gravels, and sands, which in many cases may be traced directly to the beds that have given rise to them through disintegration. The gravels have been formed by the weathering out of the flints found in the limestones, especially in the Bronson and its equivalents, the Hertha, Dennis, ard Drum limestones, and in a minor degree in the Parsons, Iola, Allen, and Piqua. Most of the limestones contain but little argillaceous and arenaceous material. The calcareous portion goes into solution and is redeposited by evaporation and pre. cipitation, so that in many places the lime content of the soil is large.

The sandstone and shale formations vary in character and lateral extent with individual beds. The Chanute shales are particularly sandy as compared with the other formations, but the soil derived from them shows a larger percentage of sand than the rocks themselves, since the sand is not so readily transported as the clay and forms surface accumulations. The soils from the remaining shale beds are largely clay soils.

The thickness of the soil is important as determining its agricultural value, and is related in large measure to the geologic formations and 
80 - ECONOMIC GEOLOGY OF IOLA QUADRANGLE, KANSAS. [BUL.. 238.

the structure of the rocks. In the areas occupied by the limestones weathering produces dip slopes on the upper surface of the limestone beds, and the migration of the soils and their transportation by running water are apt to reduce the residual material to a thin mantle. Accordingly in dry seasons these thin soils do not produce well, since they do not retain sufficient moisture.

The character of the soils has a certain influence upon the distribution of the trees. The Chanute shales, which have been described as giving rise to sandy soils, support a considerable growth of black jack (Qivercus nigra), a species that originally covered the larger areas which are otherwise prairie lands, and that still constitutes the principal timber growth on the uplands. The alluvial soils along Neosho River and the larger creeks support a mixed growth of hard woods. 


\section{INDEX.}

Page.

Adams, G. I.; work of _..._._. 12,13

Allen limestone, equivalent of fossils found in occurrence and character of -.-

Alluvium, occurrence and character of

Artesian well, diagram of .....-. Bandera shale, occurrence and character of

Bartlesville, oil wells drilled at.... Bolton, oil wells at, flow of Boone formation, occurrence and character of

Brick, production of -.-_..--

Brick industry, condition of -...-.-

Brick plant, view of _..........

Bifick plants, description of _.....-

Brickmaking, discussion of

Bristol recording pressure gage, plate showing -.........-..-

Bronson limestone, equivalents of -oceurrence and character of -.-

Callaway, L H., reference to

Casing, volume of, table showing--

Caustic-soda waste, use of, in cement manufactụre.........

Cement. See Portland cement; Puzzolan cement; Natural cement ............

Chanute, brick plants at_._....gas at, price of gas near

oil near, occurrence of oil production at._._._...... oil wells drilled at oll wells near, flow of _._._._-_ oll and gas development near.pumping station, storage tanks, and loading racks at.-

section through.

well near, view of ........... wells east of, plate showing relative positions aud $\operatorname{logs}$ of -.......--

Chanute shale, occurrence and character of ..................

Chelsea, oll wells drilled at...--Cherokee shale, occurrence and character of _-_- 16, 23, 25, 26

Cherokee-Lanyon Spelter Company, operations of

41
Page.

Cherryvale, oil production at__._._- 36 oil wells drilled at__._._._. 35

Cherryvale shale, equivalent of ...- 21 occurrence and character of _... 1s

City Improvement Company, of Iola, work of _..... 31

Clays, classification of _-

definition and composition of -- 69

occurrence of _._-_._-_._- 70-71

use of, in cement manufacture $-66,67$

Closed pressure. See Pressure, static.

Coal, occurrence and character of -- 74-75

Coffeeville Vitrified Brick and Tile Company, plant of _..- 71-72

Cold weather, operation of gas line during, method of -..-

Concreto shale, equvalent of occurrence and character of _...Crane, W. R., wolk of Daly, J. A., reference to Dennis limestone, equivalent of ...-. oceurrence and character of...Discharge of gas wells, tables for computing See also Flow; Pressure.

Distribution of gas, methods of

Drains, use of

Drilling, methods, cost, and rate of - 60-61

Drum limestone, equivalent of _._._. 21 occurrence and character of _-_.- 19

Dudley shale, occurrence and character of

Dynamic pressure. See Pressure, dynamic.

Earlton limestone, equivalent of ----' 21

Eckel, E. C., cited on silicate cements 63

Erie, gas at, price of gas near, flow of oil and gas development near -- 34 section through _........... 24

Erie Gas and Mineral Company, operations of _.... 34

Erie formation, equivalent of .....Faunal lists, correlation and correction of _-

Flow of gis in pipes, measurement of - 59-60 Flow and pressure of gas in pipes, determination of

Sce also Discharge; Pressure.

Formation names, changes in

Bull. 238-04-6 
Page.

Formations, description of

Fort scott limestone, occurrence and character of

Gage, spring, figures showing - - $45,50,51$

Gage, U -shaped, figure showing -_--- 45 use of .

Gailey and Guffey, operations by _... 31, 32

Galesburg shale, equivalent of occurrence and character of -.---

Gas. Sec Natural gas.

Ginses, properties of _............

Gold and silver, extraction of, from zine residues _...-..-

Golden Oil Company's well No. 2, view of

Guffey and Gailey, operations by

Haworth, Erasmus, work of .......

Heaters, use of

Fertha limestone, equivalent of..... occurrence and character of ...

Home Brick Company, plant of _...-

Humboldt, brick plant at_.........gas near, flow of oil and gas development near -oil production at ofl wells drilled at._._._._._-_. oil wells near, descriptions of _. 26-28 flow of -

Humboldt Brick Manufacturing Com pany, plant of .....-

Independence, oil production at .... oil wells drilled at............

Iola, brick plants at _....... gas near oil and gas development near Laharpe and.......... section through zinc smelting at_-_._-_._-

Iola Brick Company, plant of ....... plant of, view of

Iola Gas Company, operations of -.Iola limestone, equivalent of .....fossils found in occurrence and character of

Iola Poltland Cement Company, plant and limestone quar'y of, description and views of -..........

Iola quadrangle, geologic maps of -- 14, 16 geology of

location of .........

map showing -......-...

mineral resources of rocks in, general section of ...static pressure in, map showing zones of

Kansas Crude well No. 1, description of

Kansas Portland Cement Company, plant of, description of

Kansas Vitrified Brick Company, plant of -...-...-

Knapp, I. N., operations of

Knapp pumping station, storage tanks, and loading racks, view of -..--.-
Labette shale, occurrence and chatacter of

Page.

Laharpe, brick plants at _...... oil and gas development near Iola and _....... 31-32

section through

Lane shale, equivalent of......-.-.

Lanyon, W. and J., operations of ...

Lanyon Zinc Company, operations of smelter's of, views of.

Lead and zinc, occurrence of :-_.-.-

Limestone, use of, in cement manufacture _... 66,67

Limestone quarry, view of _._._. $6 \mathrm{~S}$

Loading racks, view of _-___._._. 34

McRea, L. 'T., reference to._...... 41.

Marl, use of, in cement manufacture . $\quad 66$

Martin Brothers, well of, flow of -.- $3 i$

Measurement of gas wells, methods of -

Mineral resources, discussion of --_- 30-80

Minneapolis Oil and Gas Company, well of, flow of -_.--

Mississippian series, occurrence and character of -.......

Moran, oil and gas devclopment near. section through

Moran Gas and Crude Oil Company, operations of -...-

Natural cement, characteristics of - -

Natural gas, area producing_-_._-_ $38-40$

composition of -..... 44

distribution and control of _-_.- 61-63

flow of, in pipes, measurement

of - $59-60$

production, use, and price of--- 37-3S

velocity of, determination of ... 49

utilization of, in zinc smelting $40-43$

volume of, measurement of, by increase in density -- 51-52

Natural gas wells, discharge of, titbles for computing-- 50

phenomena of, discussion of -- $43-52$ measurements of _._._._._-_._ $53-60$ volume of, measurement of

Natiral gas, oil and, developing and utilizing, methods of _- 60

movement of -...- 25

origin of -_-_-_-__-_-_-_-_ 24-25

production of, history of _... $30-34$

Natural- gas- and oil-bearing sandstones, relations of $---25-29$

Natural-gas and oil reservoirs, type of, figure showing --_ 46

Neodesha, oil production at_._._._- $\quad 36$

oil wells drilled at______._- 35

Neosho River, course and flow of _-- $75-76$

wells in valley of ........ 2S

Neosho Valley Development Company, operations of.--

New Jersey Zinc Company, operations of -...-...-..-

Nicholson, G. E., operations of ... 41

Nomenclature, changes in ....... 21-22

Oil, production of

Oil pumping, systems of 
l'age.

Oil wells, flow of -

Oil and gas, developing and utilizing, methods of ........ movement of origin of -

production of, history of -.-.--
Oil- :ind gas-bearing sandstones, relations of _._._..._. 25-29

Oil ind gas reservolrs, types of, figure showing-...-..-

Open-flow pressure. Sec I'ressure, dynamic.

Oread Dil and Gas Company, wells of, descriptions of $-26-28$

wells of, position and partial $\log$ of, figure showing----

l'almer Oil Company, operations of -

rarsons limestone, occurrence and chnracter of _._-_.-.-.

l'aullin and Pryor, prospecting by --

lawnee limestone, occurlence and character of -

Pennsylvanian series, occurrence and character of -.......

leru, oil production at

Pipes, flow of gas in, measurement of:

pressure and fow in

gas in, measurement

occurrence and character of...-.

Fitot tube, figures showing _._._. 48 ,

Portland cement, composition of --manufacture of, materials used in

methods of

physical properties of ..........

production of .................

Portland-cement materials, amount of - menter

Portland-cement plints, description of -

view of tions of:-

$-32,33$

pressure, charts showing -

discharge from, computation of, tables showing......--

Fressure and flow of gas in pipes, determination of _..... 50-51

I'ress!ure, dynamic, discussion of _..- 47-49

l'ressure, static, discussion of _.... $45-47$ measurement of -

gages for, figures showing-

l'rime Western Spelter Company, operations of ------

l'ryor and Paullin, prospecting by -rumping station, view of l'umping oil, systems of Puzzolan cement, characteristics of: Red Fork, oil wells drilled at__._. Robert Lanyon's Sons Company, operations of

Robiuson instrument, figure showingRetorts, view of _._. Sands, gas contents of Sandstone beds, disappearince of, figures showing -...--

Sandstones, oil-and gas-bearing, relations of _.

Shaler, M. K., work of

Shaw, section through

Silicate cements, types of

Silver and gold, extraction of, from zinc l'esidues_-_-_.- 49

Slag, use of, in cement manufactule_

Smeltel's, views of _-_._-

Smelting. Sce Zinc smelting.

Speltel. Sec Zinc spelter.

Soils, character of _._._._... 78-80

origin and classification of

Southwestern Development Company, operations of - 33

Spring gage, figures slowing _-_ $45,50,51$ use of _...

Springs, occurrence of _.... 77

Stanton limestone, equivalent of _-_ $\quad 21$

Star Brick Company, plant of _._. 74

Static pressure. See Pressure, static.

Stolage tanks, view of _._._._. 34

Streams, description of _._.

Structure, discussion of $\ldots \ldots+23-29$

Surface features, discussion of _--_-- 14-15

United Zinc and Chemical Company, operations of _._._. 41

Velocity of gas in wells, determination of

Vilas shale, occurrence and chalracter of ...... 20

straticriphic position of _-_-_ 21

Volume of gis -wells, mensulement of

measurement of, by increase in density

Water supply, discussion of

Well, artesion, diagram of

Well casing, volume of, table showing 52

Wells, occurrence of _._._._.

Wells, oil and gas, descilption of - $26-29$

Wolk, G. K., operations of

Zinc and lead, occurrence of _.-.-- i5

Yinc smelters, production of..._._- $\quad 87$ views of -

Zine smelting, method of utilization of gas in

Zinc spelter, production of 



\section{PUBLICATIONS OF UNITED STATES GEOLOGICAL SURVEY.}

[Bulletin No. 238.]

The serial publications of the United States Geological Survey consist of (1) Annual Reports, (2) Monographs, (3) Professional Papers, (4) Bulletins, (5) Mineral Resources, (6) Water-Supply and Irrigation Papers, (7) Topographic Atlas of United States-folios and separate sheets thereof, (8) Geologic Atlas of United States-folios thereof. The classes numbered 2, 7, and 8 are sold at cost of publication; the others are distributed free. A circular giving complete lists may be had on application.

The Professional Papers, Bulletins, and Water-Supply Papers treat of a variety of subjects, and the total number issued is large. They have therefore been classified into the following series: A, Economic geology; B, Descriptive geology; C, Systematic geology and paleontology; D, Petrography and mineralogy; E, Chemistry and physics; F, Geography; G, Miscellaneous; H, Forestry; I, Irrigation; J, Water storage; K, Pumping water; L, Quality of water; M, General hydrographic investigations; $N$, Water power; 0 , Underground waters; $P$, Hydrographic progress reports. This bulletin is the thirty-eighth in Series A and the forty-fourth in Series B, the complete lists of which follow. ( $\mathrm{PP}=$ Professional Paper; $\mathrm{B}=$ Bulletin. $)$

\section{SERIES A, ECONOMIC GEOLOGY.}

B 21. Lignites of Great Sioux Reservation: Report on region between Grand and Morenu rivers, Dakota, by Bailey Willis. 1885. 16 pp.,.5 pls. (Out of stock.)

B 46. Nature and origin of deposits of phosphate of lime, by R. A. F. Penrose, jr., with introduction by N. S. Shaler. 1888 . $143 \mathrm{pp}$. (Out of stock.)

B 65. Stratigraphy of the bituminous coul field of Pennsylvania, Ohio, and West Virginia, by I. C. White. 1891. $212 \mathrm{pp}$., $11 \mathrm{pls}$. (Ont of stock.)

B 111. Geology of Big Stone Gap conl field of Virginia and.Kentucky, by M. R. Campbell. 1893. 106 pp., 6 pls.

B 132. The disseminated lead ores of southeastern Missouri, by Arthur Winslow. $1896.31 \mathrm{pp}$.

B 138. Artesian-well prospects in Atlantic Coastal Plain region, by N. H. Darton. 1896. 228 pp., 19 pls. (Out of stock.)

B 139. Geology of Castle Mountain mining district, Montana, by W. H. Weed and L. V. Pirsson. 1896. 164 pp.; 17 pls.

B 143. Bibliography of clays and the ceramic arts, by J. C. Branner. $1896.114 \mathrm{pp}$.

B 164. Reconnaizsance on the Rio Grande coal fields of Texas, by T. W. Vaughan, including a report on igneous rocks from the San Carlos coal field, by E. C. E. Lord. $1900.100 \mathrm{pp} ., 11 \mathrm{pls}$.

B 178. El Paso tin deposits, by W. H. Weed. 1901. 15 pp., 1 pl.

B 180. Occurrence and distribution of corundum in United States, by J. H. Pratt. 1901. 98 pp., 14 pls.

B 182. A report on the economic geology of the Silverton quadrangle, Colorado, by F. L. Ransome. 1901. 266 pp., 16 pls.

B 184. Oil and gas fields of the western interior and northern Texas Conl Neasures and of the Upper Cretaceous and Tertiary of the western Gulf const, by G. I. Adams. 1901. 64 pp., 10 pls. (Out of stock.)

B 193. The geological relations and distribution of platinum and associated metals, by J. F. Kemp. 1902. 95 pp., 6 pls. (Out of stock.)

B 198. The Berea grit oil sand in the Cadiz quadrangle, Ohio, by W. T. Griswold. $1902.43 \mathrm{pp} ., 1 \mathrm{pl}$. PP1. Preliminary report on the Ketchikan mining district, Alaska, with an introductory sketch of the geology of southeastern Alaska, by Alfred Hulse Brooks. 1902.120 pp., 2 pls.

B 200. Reconnaissance of the borax deposits of Death Valley and Mohave Desert, by M. R. Campbell. 1902. 23 pp., 1 pl.

B 202. Tests for gold and silver in shales from western Kansus, by Waldemar Lindgren. 1902. 21 pp.

- PP2. Reconnaissancé of the northwestern portion 'of Seward Peninsula, Alaska; by A. J. Collier. 1902. $70 \mathrm{pp} ., 11 \mathrm{pls}$. 
PP 10. Reconnaissance from Fort Hamlin to Kotzebue Sound, Alaska; by way of Dall, Kanuti, Allen, and Kowak rivers, by W. C. Mendenhall. 1902. $68 \mathrm{pp} ., 10 \mathrm{pls}$.

PP 11. Clays of the United States east of the Mississippi River, by Heinrich Ries. 1903. 298 pp., 9 pls. PP 12. Geology of the Globe copper district, Arizona, by F. L. Ransome. 1903.168 pp., 27 pls.

B 212. Oil fields of the Texas-Louisiana Gulf Coastal Plain, by C. W. Hayes and William Kennedy. 1903. $174 \mathrm{pp} ., 11 \mathrm{pls}$.

B 213. Contributions to economic geology, 1902; S. F. Emmons, C. W. Hayes, geologists in charge. 1903. $449 \mathrm{pp}$.

PP 15..The mineral resonrces of the Mount Wrangell district, Alaska, by W. C. Mendenhall and F. C. Schrader. $1903.71 \mathrm{pp} ., 10 \mathrm{pls}$.

B 218. Conl resources of the Yukon, Alaska, by A. J. Collier. $1903.71 \mathrm{pp} ., 6 \mathrm{pls}$.

B 219. The ore deposits of Tonopah, Nevada (preliminary report), by. J. E. Spurr. $1903.31 \mathrm{pp} ., 1 \mathrm{pl}$. PP 20. A reconnaissance in northern Alaska, in 1901, by F. C. Schrader. 1904.139 pp., 16 pls.

PP 21. Geology and ore deposits of the Bisbee quadrangle, Arizona, by F.L. Ransome. 1904. 168 pp., 29 pls.

B 223. Gypsum deposits of the United States, by G. I. Adams and others. $1904.129 \mathrm{pp} ., 21 \mathrm{pls}$.

PP 24. Zinc and lead deposits of northern Arkansas, by G. I. Adams. , 1904. 118 pp., 27 pls.

PP 25. Copper deposits of the Encampment-district, Wyoming-Colorado, by A. C. Spencer. 1904. 107 pp., 2 pls.

B 225. Contributions to economic geology, 1903; S. F. Emmons, C. W. Hayes, geologists in charge. 1904. $527 \mathrm{pp} ., 1 \mathrm{pl}$.

PP 26. Economic resources of the northern Black Hills, by J. D. Irving, with contributions by S. F. Emmons and T. A. Jaggar, jr. 1904. 222 pp., 20 pls.

JP 27. A geological reconnaissance across the Bitterroot Range and Clearwater Mountains in Montana and Idaho, by Waldemar Lindgren. $1904.123 \mathrm{pp} ., 15 \mathrm{pls}$.

B 229. Tin deposits of the York region, Alaska, by A. J. Collier. 1904. 61. pp., 7 pls.

B 236. The Porcupine placer district, Alaska, by C. W. Wright: $1904.35 \mathrm{pp} ., 10 \mathrm{pls}$.

B 238. Economic geology of the Iola quadrangle, Kansas, by G. I. Adams, Erasmus Huworth, and W. R. Crane. 1904. 83 pp., 11 pls.

\section{SERIES B, DESCRIPTIVE GEOLOGY.}

B 23. Observations on the junction between the Eastern sandstone and the Keweenaw series on Keweenaw Point, Lake Superior, by R. D. Irving and T. C. Chamberlin. $1885.124 \mathrm{pp}$, $17 \mathrm{pls}$.

B 33. Notes on geology of northern California, by J. S. Diller. 1886. 23 pp. (Out of stock.)

B 39. The upper beaches and deltas of Glacial Lake Agassiz, by Warren Upham. 1887. 84 pp., 1 pl. (Out of stock:)

B 40. Changes in river courses in Washington Territory due to glaciation, by Bailey Willis. 3887. 10 pp., 4 pls. (Out of stock.)

B 45. The present condition of know!edge of the geology of Texas, by R. T. Hill. 1887. 94 pp. (Out of stock.)

B 53. The geology of Nantucket, by N. S. Shaler. $1889.55 \mathrm{pp}, 10 \mathrm{pls.} \mathrm{(Out} \mathrm{of} \mathrm{stock.)}$

B 57. A geological reconnaissance in southwestern Kansas, by Robert Hay. 1890. 49 pp., 2 pls.

B 58. The glacial boundary in western Pennsylvania, Ohio, Kentucky, Indiana, and Illinois, by G. F.

- Wright, with introduction by T. C. Chamberlin. $1890.112 \mathrm{pp} ., 8 \mathrm{pls}$. (Out of stock.)

B 67. The relations of the traps of the Newark system in the New Jersey region, by N. H. Darton. 1890. $82 \mathrm{pp}$. (Out of stock.)

- B 104. Glaciation of the Yellowstone Valley north of the Park, by. W. H. Weed. 1893. 41 pp., 4 pls.

B 108. A geological reconnaissance in central Washington, by I. C. Russell. 1893. $108 \mathrm{pp}$., $12 \mathrm{pls}$. (Out of stock.)

B 119. A geological reconnaissance in northwest Wyoming, by G. H. Eldridge. 1894. $72 \mathrm{pp} ., 4$ pls.

B 137. The geology of the Fort Riley Military Reservation and vicinity, Kansas, by Robert Hay. 1896. $35 \mathrm{pp}, 8 \mathrm{pls.}$

B 144. The moraines of the Missouri Coteau and their attendant deposits, by J. E. Todd. 1896. 71 pp., 21 pls.

B 158. The moraines of southenstern South Dakota and their attendunt deposits, by J. E. Todd. 1899. 171 pp., 27 pls.

B 159. The geology of eastern Berkshire County, Nassachusetts, by B. K..Emerson. 1899. 139 pp., 9 pls.

B 165. Contributions to the geology of Maine, by H. S. Williams and H. F. Gregory. $1900.212 \mathrm{pp}$, 14 pls.

WS 70. Geology and water resources of the Patrick and Goshen Hole quadrungles in eastern Wyoming and western Nebraska, by G. I. Adams. 1902. 50 pp., 11 pls.

B 199. Geology and water resources of the Snake River Plains of Idaho, by I. C. Russell. 1902. 192. 。 pp., 25 pls.

PP 1. Preliminary report on the Ketchikan mining district, Alaska, with an introductory sketch of the geology of southeastern Alaska, by A. H. Brooks. 1902. 120 pp., 2 pls. 
PP... Reconnaisance of the northwestern portion of Seward Peninsula, Alaska, by A. J..Collier. 1902. 70 pp., 11 pls:

I'P 3. Geology and petrography of Crater Lake National Park, by J. S. Diller and H. B. Patton. 1902. 167 pp., 19 pls.

PP 10. Reconnaissance from Fort Hamlin to Kotzebue Sound, Alaska, by way of Dall, Kanuti; Allen, and Kowak rivers, by W. C. Mendenhall. 1902. 68 pp., 10 pls.

PP 11. Clays of the United Stätes enst of the Nississippi River, by Heinrich Ries. 1903. 298 pp., 9 pls.

PP 12. Geology of the Globe copper district, Arizona, by F. L. Ransome. 1903.168 pp., 27 pls.

PP 13. Drainage modifications in sonthenstern Ohio and adjacent parts of West Virginin and Kentucky, by W. G. Tight. $1903.111 \mathrm{pp} ., 17 \mathrm{pls}$.

B 208. Descriptive geology of Nevada south of the fortieth parallel and adjacent portions of California, by J. E. Spurr. 1903. 229 pp., 8 pls.

B 209. Geology of Ascutney Mountain, Vermont, by R. A. Daly. $1903.122 \mathrm{pp} ., 7 \mathrm{pls}$.

WS 78. Preliminary report on artesian basins in southwestern Idaho and southeastern Oregon, by I. C. Russell. 1903. $51 \mathrm{pp} ., 2 \mathrm{pls}$.

PP 15. Mineral resources of the Mount Wrangell district, Aluska, by W. C. Mendenhall and F. C. Schrader. 1903. 71 pp., 10 pls.

PP 17. Preliminary report on the geology and water resources of Nebraska west of the one hundred and third meridian, by N. H. Darton. 1903. $69 \mathrm{pp} ., 43 \mathrm{pls}$.

B 217. Notes on the geology of southwestern Idaho and southeastern Oregon, by I. C. RusselI, 1903. 83 pp., 18 pls.

B 219. The ore deposits of Tonopah, Nevada (preliminary report), by J. E. Spurr. 1903. 31 pp., 1 pl.

PP 20. A reconnaissance in northern Alaska in 1901, by F. C. Schrader. 1904.139 pp., 16 pls.

PP 21. The geology and ore deposits of the Bisbee quadrangle, Arizona, by F. L. Ransome. 1904. 168 pp., 29 pls.

WS 90. Geology and water resources of part of the lower Jumes River Valley, South Dakota, by J. E. Todd and C. N. Hall. 1904.47 pp., 23 pls.

PP 25. The copperdeposits of the Enoumpment district, Wyoming, by A.C. Spencer. 1904. $107 \mathrm{pp} ., 2 \mathrm{pls.}$

PP 26. Economic resources of northem. Black Hills, by .J. D. Irving, with chapters by S. P. Emmons and T. A. Jaggar, jr. 1904.222 pp., 20 pls.

PP 27. Geological reconnaissance across the Bitterroot Range and the Clearwater Mountains in Montana and Idaho, by Waldemar Lindgren. 1904.122 pp., 15 pls.

PP 31. Preliminary report on the geology of the Arbuckle and Wichita mountains in Indian Territory and Oklahoma, by J. A. Taff, with an appendix on reported ore deposits in the Wichita Mountains, by H. F. Bain. 1904. 97 pp., 8 pls.

B 235. A geological reconnaissance across the Cascade Range near the forty-ninth parallel, by G. 0 . Smith and F. C. Calkins. 1904.103 pp., 4 pls.

B 236. The Porcupine placer district, Alaska, by C. W. Wright. $1904.35 \mathrm{pp} ., 10 \mathrm{pls}$.

B 237. Petrography and geology of the igneous rocks of the Highwood Mountains, Montana, by L. V. Pirsson. 1904. - pp., 7 pls.

B 238. Ecomomic geology of the Iola quadrangle, Kansas, by G. I. Adams, Erasmus Haworth, and W. R. Crane. 1904. 83 pp., 11 pls.

Correspondence should be addressed to

The Director,

United States Grological Survey, WASHINGTON, D. C.

November, 1904. 